\title{
Integrated Paleocene calcareous plankton magnetobiochronology and stable isotope stratigraphy: DSDP Site 384 (NW Atlantic Ocean)
}

\author{
W.A. Berggren ${ }^{\mathrm{a}, *}$, M.-P. Aubry ${ }^{\mathrm{b}}$, M. van Fossen ${ }^{\mathrm{c}, 1}$, D.V. Kent ${ }^{\mathrm{c}, \mathrm{d}}$, \\ R.D. Norris ${ }^{a}$, F. Quillévéré ${ }^{b}$ \\ ${ }^{a}$ Department of Geology and Geophysics, Woods Hole Oceanographic Institution, Woods Hole, MA 0254, USA \\ ${ }^{\mathrm{b}}$ Institut des Sciences de l'Evolution, Université Montpellier II, Place Eugene Bataillon, F-34095 Montpellier Cedex, France \\ ${ }^{\mathrm{c}}$ Lamont-Doherty Earth Observatory, Palisades, NY 10964, USA \\ ' Department of Geological Sciences, Rutgers University, Piscataway, NJ 08854, USA
}

Received 14 May 1999; accepted for publication 22 November 1999

\begin{abstract}
At Deep Sea Drilling Site 384 (J-Anomaly Ridge, Grand Banks Continental Rise, NW Atlantic Ocean) Paleocene nannofossil chalks and oozes $(\sim 70 \mathrm{~m}$ thick) are unconformably/disconformably underlain ( $\sim 168 \mathrm{~m}$; upper Maastrichtian) and overlain ( $98.7 \mathrm{~m}$; upper lower Eocene) by sediments of comparable lithologies. The chalks are more indurated in stratigraphically higher levels of the Paleocene reflecting increasing amounts of biosiliceous (radiolarians and diatoms) components. This site serves as an excellent location for an integrated calcareous and siliceous microfossil zonal stratigraphy and stable isotope stratigraphy. We report the results of a magnetostratigraphic study which, when incorporated with published magnetostratigraphic results, reveals an essentially complete magnetostratigraphic record spanning the interval from Magnetochron C31n (late Maastrichtian) to C25n (partim) (late Paleocene, Thanetian). Integrated magnetobiochronology and stable isotope stratigraphy support the interpretation of, and constrain the estimated duration of, a short hiatus ( $\sim 0.9$ my) within the younger part of Chron $\mathrm{C} 29 \mathrm{r}$ (including the K/P boundary) and an $\sim 6$ my hiatus separating upper Paleocene (Magnetozone C25n) and upper lower Eocene (Magnetozone C22r) sediments. Some 30 planktonic foraminiferal datum levels [including the criteria used to denote the Paleocene planktonic foraminiferal (sub)tropical zonal scheme of Berggren and Miller, Micropaleontology 34 (4) (1988) 362-380 and Berggren et al., SEPM Spec. Publ. 54 (1995) 129-212, Geol. Soc. Am. Bull. 107 (11) (1995) 1272-1287], and nearly two dozen calcareous nannoplankton datum levels have been recognized and calibrated to the magnetochronology. Planktonic foraminiferal Subzones P4a and P4b of (upper Paleocene) Zone P4 are emended/redefined based on the discovery of a longer stratigraphic extension of Acarinina subsphaerica (into at last Magnetozone C25n). Stable isotope stratigraphies from benthic foraminifera and fine fraction $(<38 \mu \mathrm{m})$ carbonate have been calibrated to the biochronology and magnetostratigraphy. A minimum in benthic foraminifer $\delta^{13} \mathrm{C}$ was reached near the Danian/Selandian boundary (within Chron C26r, planktonic foraminiferal Zone P3a and calcareous nannoplankton Zone NP4) and is followed by the rise to maximum $\delta^{13} \mathrm{C}$ values in the late Thanetian (near the base of $\mathrm{C} 25 \mathrm{n}$, in Zone P4c and NP9a, respectively) that can be used for global correlation in the Paleocene. (C) 2000 Elsevier Science B.V. All rights reserved.
\end{abstract}

\footnotetext{
* Corresponding author. Tel.: + 1-508-548-1400; Fax: + 1-508-457-2187.

E-mail address: wberggren@whoi.edu (W.A. Berggren)

${ }^{1}$ Present address: 18220 Ballinger Way, NE, Lake Forest Park, WA 98155, USA.
} 


\section{Introduction}

An integrated geochronology for the Paleocene Epoch/Series and its corollary, an integrated global biostratigraphic correlation framework, have been hampered by the general absence of reliable, low latitude magnetostratigraphies. Few sections have yielded a magneto- and biostratigraphic record of sufficient quality to serve for the establishment of a reliable Paleocene magnetobiochronology. Thick Paleocene sections were recovered from Walvis Ridge (Sites 525, 527, 528), but, in addition to slumping and unconformities, magnetostratigraphy is of poor quality (Chave, 1984). Holes 577 and 577A yield good magneto- and calcareous nannofossil stratigraphy but the Paleocene interval is thin $(<30 \mathrm{~m})$ in both sections and not all polarity events were identified (Monechi et al., 1985). Finally, the Gubbio sections that constitute magnetostratigraphic reference sections for a large part of the upper Cretaceous and the Paleogene yield an equivocal Paleocene magnetic record (Alvarez et al., 1977; Napoleone et al., 1983).

The calcareous plankton biostratigraphic record at Deep Sea Drilling Site 384 (J-Anomaly Ridge, Grand Banks Continental Rise, NW Atlantic Ocean) played an integral role in the construction of the Paleocene part of the recently published Cenozoic integrated magnetobiochronologic scale of Berggren et al. (1995a,b). However, the basic magnetostratigraphy of the Paleocene at that site has never been published save for initial investigations (conducted over 20 years ago; Larson and Opdyke, 1979) on the upper Cretaceous (Maastrichtian) and basal Paleocene (Magnetochrons C31n-C28n interval).

A nearly complete Paleocene stratigraphic record was recovered at DSDP Site 384 (NW Atlantic). A magnetostratigraphic signature which spanned the upper Maastrichtian (Chrons C30 $31)$ to lower Paleocene ( Chron C28) interval (Larson and Opdyke, 1979) suggested that a reliable magnetostratigraphy might exist for the $\sim 70 \mathrm{~m}$ of Paleocene chalks and oozes at this site. A preliminary investigation (Berggren et al., 1994) revealed that Hole 384 did, indeed, contain a stable, reliable magnetostratigraphic record spanning Chrons C25n to C31n.
The Paleocene part of the integrated magnetobiochronologic scale (IMBS) of Berggren et al. $(1995=$ BKSA95, herein) was based, primarily, on integrating the calcareous plankton biostratigraphy with the (undocumented) magnetostratigraphy of Hole 384 which was calibrated, in turn, to the Geomagnetic Polarity Time Scale (GPTS) of Cande and Kent $(1995=$ CK95, herein $)$. In this paper we document the magnetostratigraphy of Hole 384; the basic investigation/measurements were made by MVF to which have been added/incorporated the original data of Larson and Opdyke (1979); the synthesis of the magnetostratigraphic data has been conducted by DVK. The original studies on calcareous nannoplankton and planktonic foraminifera were conducted by MPA and WAB, respectively. We have examined planktonic foraminifera in over 60 samples (16 were picked quantitatively) and calcareous nannofossils in over 80 samples with a view to corroborating/improving upon the magnetobiostratigraphic correlation/calibration to the geomagnetic polarity time scale of Cande and Kent (1995) as incorporated in the integrated magnetobiochronology of Berggren et al. (1995a,b). Additional, qualitative and quantitative studies on planktonic foraminifera, based on more closely spaced sampling, have been conducted by FQ. Finally, stable isotope data on Hole 384 have been contributed by RDN based on studies by Corfield and Norris (1996) and additional analysis.

\section{DSDP Site 384}

\subsection{Location}

DSDP Site 384 (latitude: $40^{\circ} 21.65^{\prime} \mathrm{N}$; longitude: $51^{\circ} 39.80^{\prime} \mathrm{W} ; 3909 \mathrm{~m}$ water depth; Tucholke et al., 1979) is located on the $J$-Anomaly Ridge where it emerges above the Sohm Abyssal Plain and Grand Banks Continental Rise, NW Atlantic Ocean (Fig. 1). It lies between Anomalies M2 and M3 (Rabinowitz et al., 1979) indicating a basement age of about $124 \mathrm{Ma}$ (Gradstein et al., 1995). Backtracking indicates that paleodepth varied from $\sim 3000 \mathrm{~m}$ in the earliest Paleocene to 


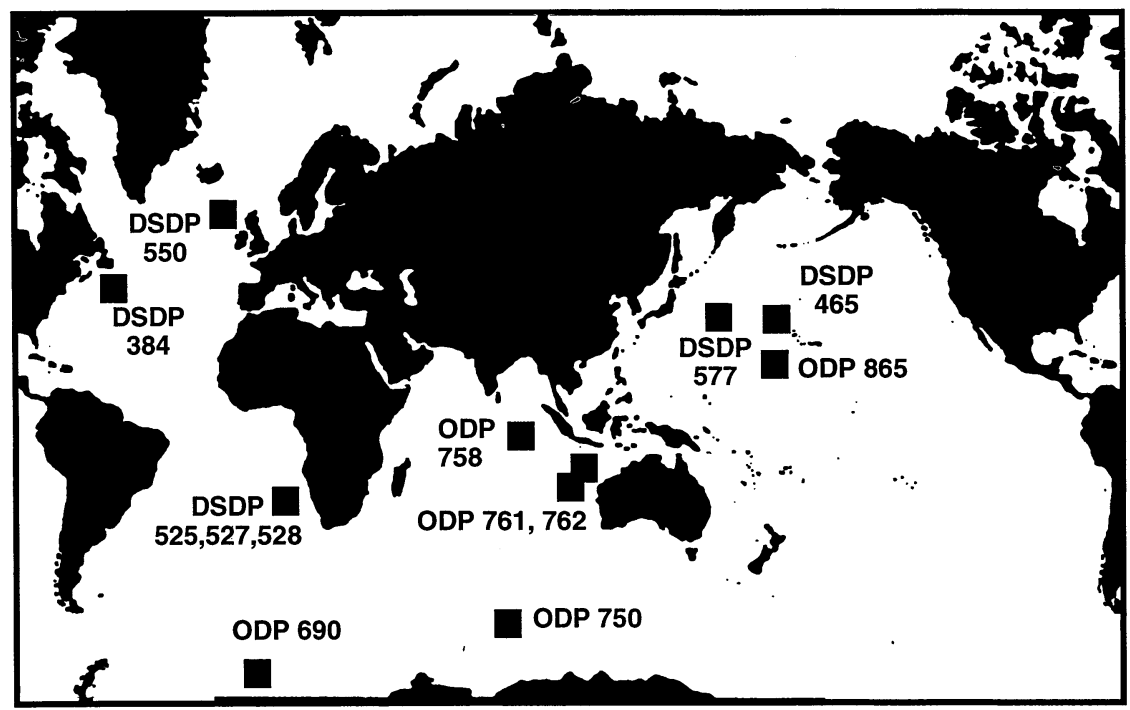

Fig. 1. DSDP Site 384 location map.

$\sim 3500 \mathrm{~m}$ in the latest Paleocene (Tucholke and Vogt, 1979).

The hole was washed down to $50 \mathrm{~m}$ where middle Eocene nannofossil oozes were recovered. It bottomed at $324.8 \mathrm{~m}$ in altered vesicular basalt basement overlain by sediments of late Barremian to early Albian age. The interval between 69.3 and $167.9 \mathrm{~m}$ (Core 6-1 to Core 13-3, $33 \mathrm{~cm}$ ) was continuously cored and recovery was good (82\%). It consists of Paleocene ooze and chalk which, because of deposition well above the CCD and in a quiescent environment (Tucholke and Vogt, 1979), and shallow burial, provide pristine material suitable for biostratigraphic, magnetostratigraphic and isotopic investigations.

\subsection{Lithostratigraphy}

The $69.3 \mathrm{~m}$ section of Paleocene nannofossil chalks and oozes (Unit IB) is unconformably/ disconformably underlain at $384-13-3, \quad 33 \mathrm{~cm}$ (167.93 mbsf; upper Maastrichtian; Unit IC) and overlain at 384-6-1, $15 \mathrm{~cm}$ (98.60 m; upper lower Eocene; Unit IA), respectively, by sediments of comparable lithologies (Fig. 2). The upper Paleocene/lower Eocene contact was not recovered, but a $\sim 40 \mathrm{~cm}$ interval of chert, chalk and limestone at the base of the lower Eocene section has been equated with Seismic 'Horizon Ac'. The Cretaceous/Paleogene boundary is marked "by a faint but distinct color change and burrow mottling change" (Tucholke et al., 1979, p. 112), and a zone of mixing occurs in the uppermost part of Unit IC.

The Paleocene chalks are more indurated in stratigraphically higher cores, a reflection of fluctuating, but increasing amounts of biosiliceous material (radiolaria and diatoms). Whereas Cores 13 and 12 contain high percentages of carbonate $(\sim 70-80 \%)$, a notable increase in biosiliceous components occurs in Core 11 and above (with concomitant decrease in carbonate to $\sim 60-70 \%$ ); dissolution is strong in some samples in Cores 9 to 6 , and the biosiliceous component may exceed $90 \%$ of the coarse fraction in some intervals (Boersma et al., 1979). Fom Core 7-2 to the base of Unit 1B, moderate mottling occurs, the mottling having 1 to $2 \%$ amorphous iron oxide and/or opaques including hematite. Sedimentation rates were estimated to have varied from $\sim 6-10 \mathrm{~m} / \mathrm{my}$ during the late Cretaceous and early Paleocene to $\sim 20 \mathrm{~m} / \mathrm{my}$ during the late early (or mid-) Paleocene (Tucholke et al., 1979, pp. 107, 126). 


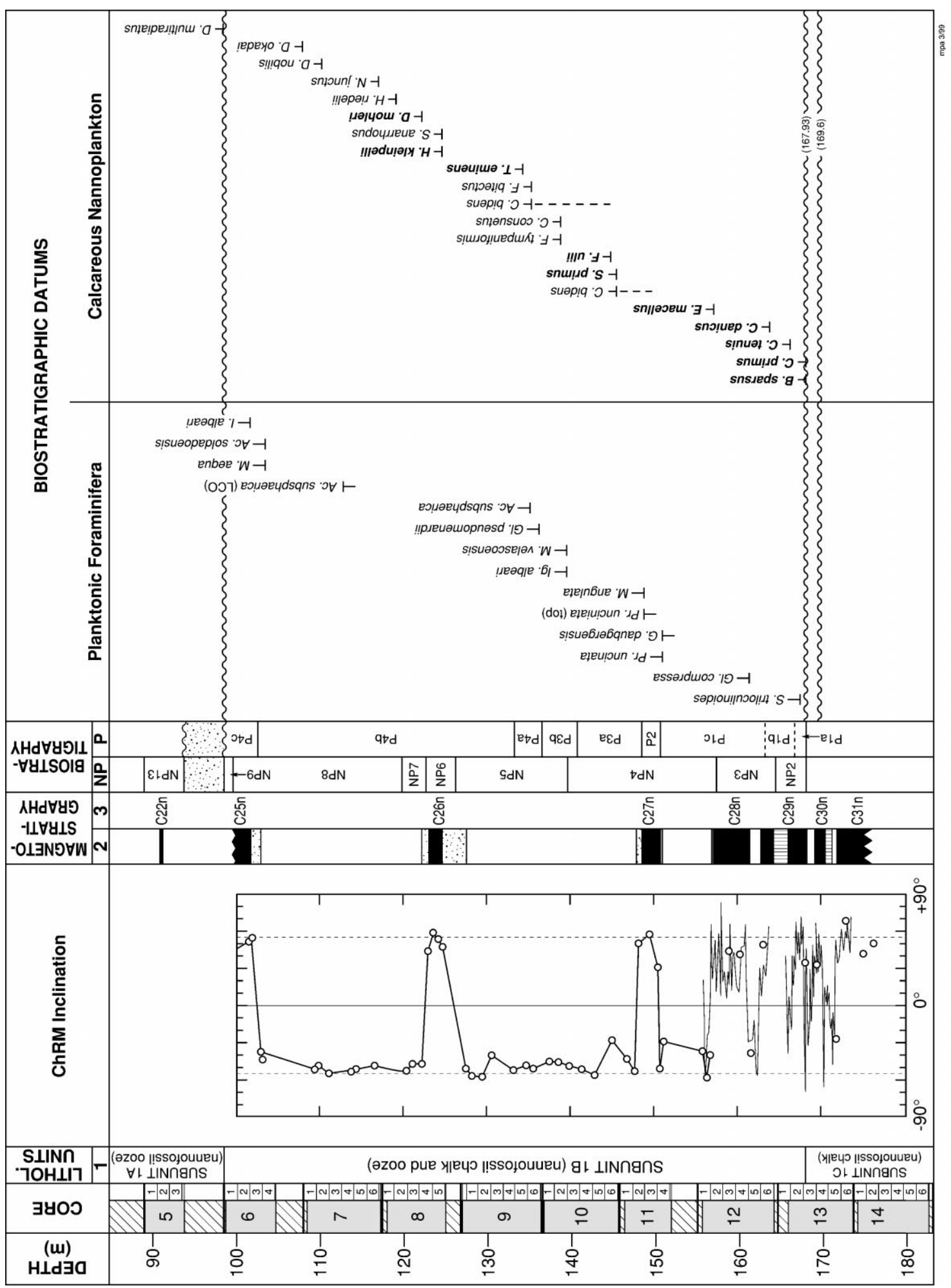




\section{Biostratigraphy}

\subsection{Planktonic foraminifera}

Some 60 samples were washed over a $65 \mu \mathrm{m}$ screen, dried and sieved into $250 \mu \mathrm{m}, 149 \mu \mathrm{m}$, and $63 \mu \mathrm{m}$ size fractions. 16 samples were picked quantitatively; approximately 200 specimens were picked from each fraction for a total of $\sim 600$ specimens/sample. Semiquantitative analysis was made on each of the remaining samples in order to determine the lowest and highest occurrences ( $\mathrm{LO}$ and $\mathrm{HO}$, respectively) of taxa. In this paper, we differentiate between the lowest (LO) and highest (HO) stratigraphic occurrences and the earliest/oldest (FAD) and latest/youngest (LAD) temporal occurrences of fossil taxa following the more detailed definition of Aubry (1995).

About 15,000 specimens have been picked/ determined in this manner. Illustration of selected specimens has been made on a JEOLCO scanning electron microscope at the University of Montpellier.

The planktonic foraminiferal biostratigraphy of Site 384 was originally investigated (Berggren and Norris, 1993; Berggren in BKSA95) with a view to improving upon the preliminary biostratigraphic data presented in the (essentially) stable isotope studies of Boersma et al. (1979) for the Initial Reports of DSDP Leg 43 (Tucholke et al., 1979). The Paleocene planktonic foraminifera from this site were studied qualitatively by Berggren and Norris (1997) as part of an investigation of global (sub)tropical Paleocene planktonic foraminiferal taxonomy and biostratigraphy (Fig. 2). The stratigraphic ranges of $\sim 40$ taxa were delineated over the $\sim 70 \mathrm{~m}$ thick Paleocene stratigraphic interval of Zones P1b-P4c (partim; $\mathrm{P}$ zones of Berggren and Miller, 1988 and Berggren et al., 1995) and (calcareous nannoplankton) Zones NP2-NP9 (partim; NP zones of Martini, 1971). We have not found evidence of the basal Paleocene Zone P $\alpha$ at Site 384 (cf. Boersma et al., 1979; Okada and Thierstein, 1979). Quillévéré (1996) also made a quantitative examination of planktonic foraminifera at Site 384 using more dense sample spacing (see below) with a view towards further improving upon the Paleocene part of the IMBS. As a result we report below several additional biostratigraphic datum levels to those identified in BKSA95 (Fig. 3, Table 1). In addition evidence from Site 384, together with observations at several other Paleocene sites, necessitates a revision to the subzonal subdivision of Zone P4 as defined in BKSA95 (see below). Representative taxa are illustrated in Plates I-VI.

\subsection{Calcareous nannoplankton}

Standard smear slides were prepared for calcareous nannofossil analysis. 82 samples were examined. In order to obtain the tightest possible correlations most samples that were examined for magnetostratigraphy were also analyzed for calcareous nannofossil stratigraphy. Qualitative analysis based on thorough examination of smear slides has been conducted using a Zeiss photomicroscope. Qualitative and quantitative analyses yield similar results when both are diligently conducted (Aubry and Villa, 1996).

The remarkable quality of the Paleocene calcareous nannofossil record at Site 384 was recognized by Okada and Thierstein (1979; see also Bralower and Parrow, 1996) who were first to establish the calcareous nannofossil stratigraphy of the site and to delineate a number of datum events in addition to those provided by the zonal markers. Thierstein and Okada (1979) also conducted a detailed analy-

Fig. 2. The Paleocene section at DSDP Site 384. Lithostratigraphy and core recovery, magnetostratigraphy and biostratigraphy (lowest [LO] and highest [HO] occurrences of calcareous plankton) in uppermost Cretaceous and Paleocene sediments of Hole 384. Magnetostratigraphy of the lowermost Eocene, Paleocene, and uppermost Cretaceous section of Site 384 based on inclination of the B magnetization (see Fig. 5B). Large open symbols = this paper; small open symbols=Larson and Opdyke (1979). The reversed polarity interval in Core $5-3,39 \mathrm{~cm}$ to $5-2,111 \mathrm{~cm}$ is correlative with Zone NP13, and represents Chron C22r. Thus the unconformable/disconformable Paleocene/Eocene contact at $98.6 \mathrm{mbsf}$ corresponds to a $\sim 6$ my hiatus that spans the interval from $\sim 56.2 \mathrm{Ma}$ to $50.2 \mathrm{Ma}$. 


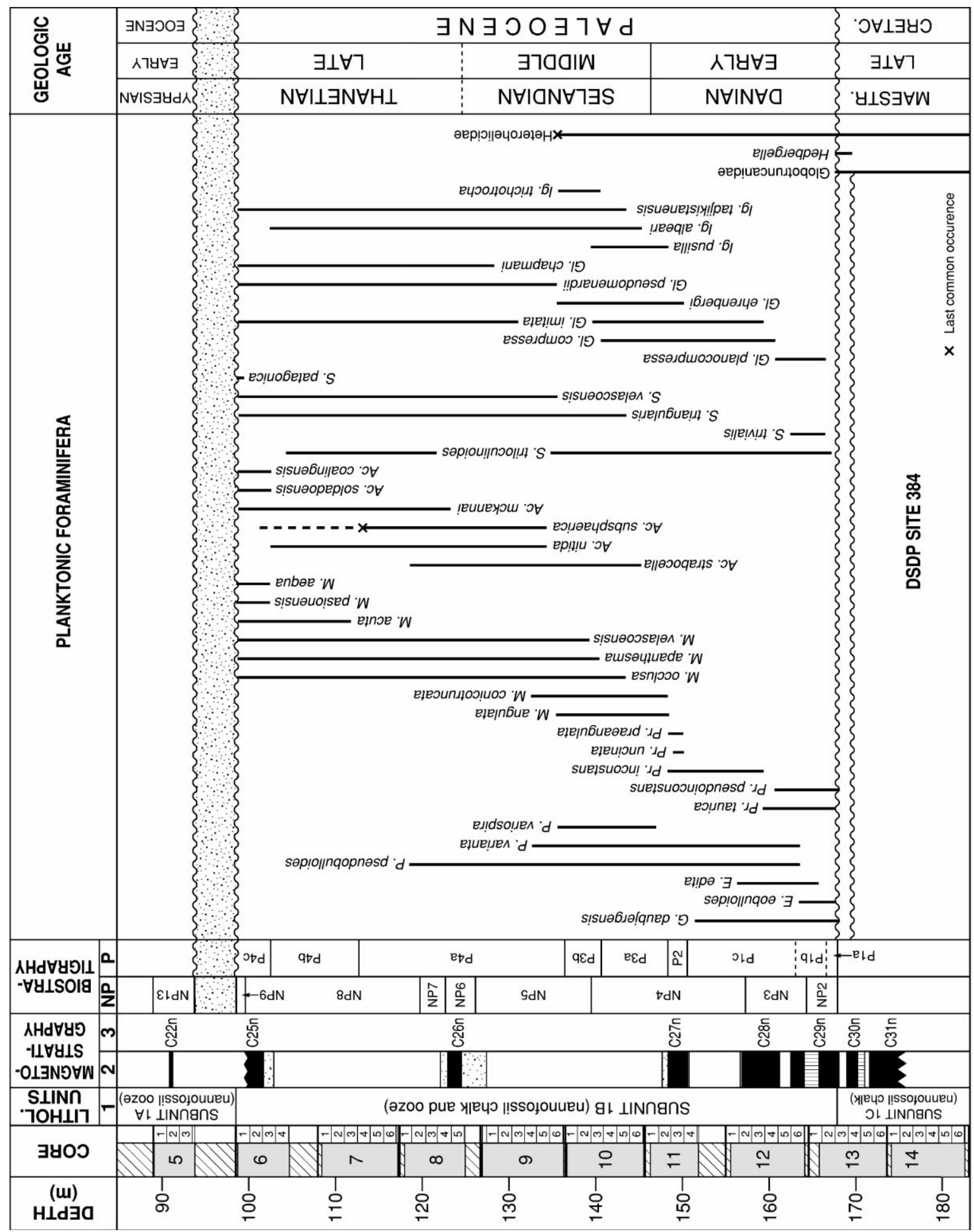


Table 1

Paleocene planktonic foraminiferal datum events delineated in DSDP Hole 384. Datums in bold characters are new

\begin{tabular}{|c|c|c|c|c|c|c|c|c|c|}
\hline Datum & FAD & LAD & Chron & Age (Ma) & Samples & & Depths (m) & & Mid-depth (m) \\
\hline Ac. nitida & & $\mathrm{X}$ & $\mathrm{C} 25 \mathrm{r}$ & 56.3 & 6/3: $30-34$ & 6/3: 92-94 & 101.90 & 102.52 & 101.71 \\
\hline Ac. mckannai & & $\mathrm{X}$ & $\mathrm{C} 25 \mathrm{r}$ & 56.3 & 6/3: $30-34$ & 6/3: 92-94 & 101.90 & 102.52 & 101.71 \\
\hline Ig. albeari & & $\mathrm{X}$ & $\mathrm{C} 25 \mathrm{r}$ & 56.3 & $6 / 3: 30-34$ & 6/3: 92-94 & 101.90 & 102.52 & 101.71 \\
\hline Ac. soldadoensis & $\mathrm{X}$ & & $\mathrm{C} 25 \mathrm{r}$ & 56.5 & 6/3: 92-94 & $6 / 4: 130-132$ & 102.52 & 104.40 & 103.46 \\
\hline Ac. coalingensis & $\mathrm{X}$ & & $\mathrm{C} 25 \mathrm{r}$ & 56.5 & 6/3: 92-94 & $6 / 4: 130-132$ & 102.52 & 104.40 & 103.46 \\
\hline M. аеqua & $\mathrm{X}$ & & $\mathrm{C} 25 \mathrm{r}$ & 56.5 & 6/3: 92-94 & $6 / 4: 130-132$ & 102.52 & 104.40 & 103.46 \\
\hline S. triloculinoides & & $\mathrm{X}$ & $\mathrm{C} 25 \mathrm{r}$ & 56.5 & 6/3: 92-94 & 6/4: 130-132 & 102.52 & 104.40 & 103.46 \\
\hline Ac. subsphaerica & & $\mathrm{LCO}$ & $\mathrm{C} 26 \mathrm{r}$ & 57.1 & $7 / 3: 92-94$ & $7 / 4: 130-132$ & 111.92 & 113.80 & 112.86 \\
\hline M. conicotruncata & & $\mathrm{X}$ & $\mathrm{C} 26 \mathrm{r}$ & 58.8 & 9/3: 136-138 & 9/4: 136-138 & 131.28 & 132.76 & 132.02 \\
\hline$P$. varianta & & $\mathrm{X}$ & $\mathrm{C} 26 \mathrm{r}$ & 58.8 & 9/3: 136-138 & 9/4: 136-138 & 131.28 & 132.76 & 132.02 \\
\hline M. angulata & & $\mathrm{X}$ & $\mathrm{C} 26 \mathrm{r}$ & 59.1 & 9/4: 136-138 & 9/5: 136-138 & 132.76 & 134.26 & 133.51 \\
\hline Ig. trichotrocha & & $\mathrm{X}$ & $\mathrm{C} 26 \mathrm{r}$ & 59.1 & 9/4: 136-138 & 9/5: 136-138 & 132.76 & 134.26 & 133.51 \\
\hline Ac. nitida & $\mathrm{X}$ & & $\mathrm{C} 26 \mathrm{r}$ & 59.2 & 9/5: 136-138 & 9/6: 136-138 & 134.26 & 135.78 & 135.02 \\
\hline Ac. subsphaerica & $\mathrm{X}$ & & $\mathrm{C} 26 \mathrm{r}$ & 59.2 & $9 / 5: 136-138$ & $9 / 6: 136-138$ & 134.26 & 135.78 & 135.02 \\
\hline$P$. variospira & & $X$ & $\mathrm{C} 26 \mathrm{r}$ & 59.2 & 9/5: 136-138 & 9/6: 136-138 & 134.26 & 135.78 & 135.02 \\
\hline S. velascoensis & $\mathrm{X}$ & & $\mathrm{C} 26 \mathrm{r}$ & 59.4 & 9/6: 136-138 & $9 / \mathrm{CC}$ & 135.78 & 136.40 & 136.09 \\
\hline Gl. Pseudomenardii & $\mathrm{X}$ & & $\mathrm{C} 26 \mathrm{r}$ & 59.4 & $9 / 6: 136-138$ & $9 / \mathrm{CC}$ & 135.78 & 136.40 & 136.09 \\
\hline M. velascoensis & $\mathrm{X}$ & & $\mathrm{C} 26 \mathrm{r}$ & 60 & 10/2: $136-138$ & $10 / 3: 10-14$ & 139.26 & 139.50 & 139.38 \\
\hline Ig. albeari & $\mathrm{X}$ & & $\mathrm{C} 26 \mathrm{r}$ & 60 & 10/2: 136-138 & 10/3: $10-14$ & 139.26 & 139.50 & 139.38 \\
\hline Ig. pusilla & & $\mathrm{X}$ & $\mathrm{C} 26 \mathrm{r}$ & 60 & 10/2: $136-138$ & 10/3: $10-14$ & 139.26 & 139.50 & 139.38 \\
\hline Ig. trichotrocha & $\mathrm{X}$ & & $\mathrm{C} 26 \mathrm{r}$ & 60.2 & $10 / 3: 124-126$ & 10/4: $136-138$ & 140.76 & 142.26 & 141.51 \\
\hline M. apanthesma & $\mathrm{X}$ & & $\mathrm{C} 26 \mathrm{r}$ & 60.2 & $10 / 3: 124-126$ & 10/4: $136-138$ & 140.76 & 142.26 & 141.51 \\
\hline Ig. tadjikistanensis & $\mathrm{X}$ & & $\mathrm{C} 26 \mathrm{r}$ & 60.5 & 10/5: 136-138 & 10/6: 136-138 & 143.76 & 145.26 & 144.51 \\
\hline Ac. strabocella & $\mathrm{X}$ & & $\mathrm{C} 26 \mathrm{r}$ & 60.6 & 10/6: $136-138$ & $10 / \mathrm{CC}$ & 145.26 & 145.70 & 145.48 \\
\hline Ig. aff. albeari & $\mathrm{X}$ & & $\mathrm{C} 26 \mathrm{r}$ & 60.7 & 10/6: $136-138$ & 11/1: $136-138$ & 145.26 & 147.06 & 146.16 \\
\hline$P$. variospira & $\mathrm{X}$ & & $\mathrm{C} 26 \mathrm{r}$ & 60.9 & 11/1: 136-138 & 11/2: $118-120$ & 147.06 & 148.38 & 147.72 \\
\hline M. conicotruncata & $\mathrm{X}$ & & $\mathrm{C} 26 \mathrm{r}$ & 60.9 & 11/1: 136-138 & 11/2: $118-120$ & 147.06 & 148.38 & 147.72 \\
\hline Pr. inconstans & & $\mathrm{X}$ & $\mathrm{C} 26 \mathrm{r}$ & 60.9 & 11/1: 136-138 & 11/2: $118-120$ & 147.06 & 148.38 & 147.72 \\
\hline M. praeangulata & & $\mathrm{X}$ & $\mathrm{C} 26 \mathrm{r}$ & 60.9 & 11/1: 136-138 & 11/2: $118-120$ & 147.06 & 148.38 & 147.72 \\
\hline Ig. pusilla & $\mathrm{X}$ & & $\mathrm{C} 27 \mathrm{n}$ & 61 & $11 / 2: 118-120$ & $11 / 3: 30-32$ & 148.38 & 149.00 & 148.69 \\
\hline M. angulata & $\mathrm{X}$ & & $\mathrm{C} 27 \mathrm{n}$ & 61 & 11/2: $118-120$ & $11 / 3: 30-32$ & 148.38 & 149.00 & 148.69 \\
\hline Pr. uncinata & & $\mathrm{X}$ & $\mathrm{C} 27 \mathrm{n}$ & 61 & 11/2: $118-120$ & 11/3: 30-32 & 148.38 & 149.00 & 148.69 \\
\hline Pr. uncinata & $\mathrm{X}$ & & $\mathrm{C} 27 \mathrm{n}$ & 61.2 & $11 / 3: 136-138$ & 11/4: $136-138$ & 150.06 & 151.56 & 148.69 \\
\hline M. praeangulata & $\mathrm{X}$ & & $\mathrm{C} 27 \mathrm{n}$ & 61.2 & 11/3: 136-138 & 11/4: 136-138 & 150.06 & 151.56 & 148.69 \\
\hline G. daubjergensis & & $\mathrm{X}$ & $\mathrm{C} 27 \mathrm{n}$ & 61.2 & 11/3: 136-138 & 11/4: 136-138 & 150.06 & 151.56 & 148.69 \\
\hline Pr. taurica & & $\mathrm{X}$ & $\mathrm{C} 28 \mathrm{n}$ & 62.9 & $12 / 3: 136-138$ & 12/4: $136-138$ & 158.90 & 160.90 & 159.9 \\
\hline Pr. inconstans & $\mathrm{X}$ & & $\mathrm{C} 28 \mathrm{n}$ & 63 & 12/4: $136-138$ & $12 / 5: 30-32$ & 160.86 & 161.30 & 161.08 \\
\hline Gl. compressa & $\mathrm{X}$ & & $\mathrm{C} 28 \mathrm{n}$ & 63 & 12/4: $136-138$ & $12 / 5: 30-32$ & 160.86 & 161.30 & 161.08 \\
\hline P. varianta & $\mathrm{X}$ & & $\mathrm{C} 28 \mathrm{n}$ & 63 & 12/4: $136-138$ & $12 / 5: 30-32$ & 160.86 & 161.30 & 161.08 \\
\hline S. triloculinoides & $\mathrm{X}$ & & $\mathrm{C} 29 \mathrm{n}$ & 64.3 & $13 / 2: 120-121.5$ & $13 / 2: 120-121.5$ & 167.19 & 167.30 & 167.25 \\
\hline
\end{tabular}

sis of the changes that occur in the calcareous nannofossil assemblages through a $\sim 2 \mathrm{~m}$ thick interval that encompasses the Cretaceous/ Paleogene boundary at $167.93 \mathrm{mbsf}$. Among other results, they determined that the section was continuous across the $\mathrm{K} / \mathrm{P}$ boundary and proposed an alternative interpretation of the magnetostratigraphy established by Larson and Opdyke (1979).

Fig. 3. Stratigraphic ranges of common Paleocene planktonic foraminifera in DSDP Hole 384. G. = Globoconusa; E. =Eoglobigerina; $P .=$ Parasubbotina $;$ Pr. $=$ Praemurica $;$ M. = Morozovella $;$ Ac. $=$ Acarinina $;$ S. $=$ Subbotina $;$ Gl.$=$ Globanomalina $;.=$ Igorina. 
PLATE I
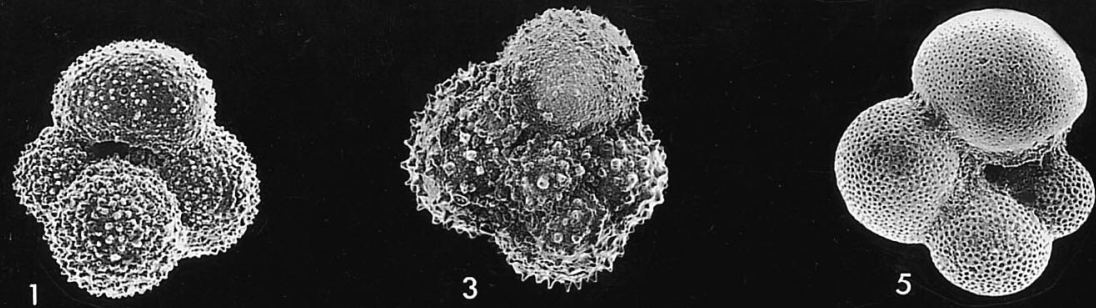

13. 207.250 . 150, 20 .

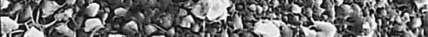

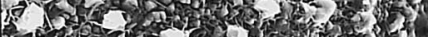

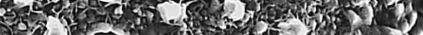

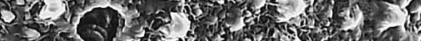

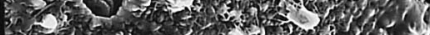

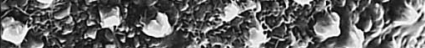

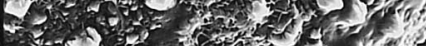

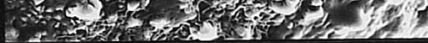

2

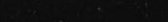

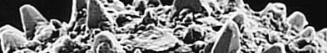

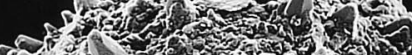

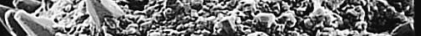

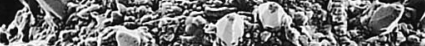

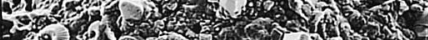

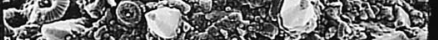

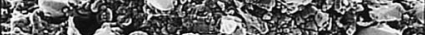

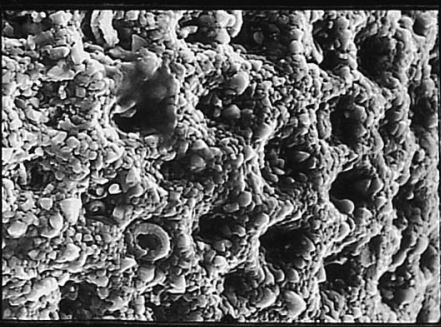

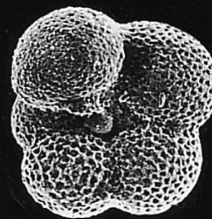

8

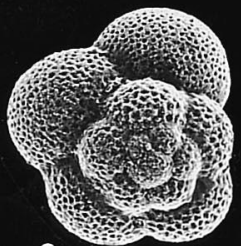

9

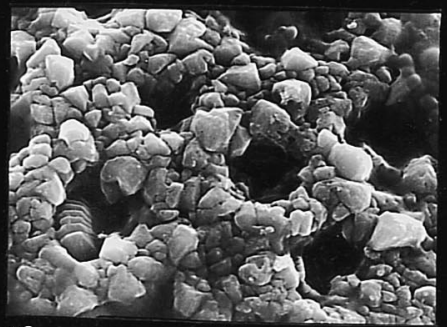

10

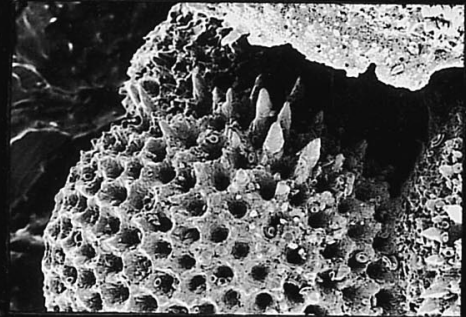

12

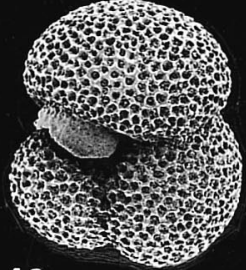

13

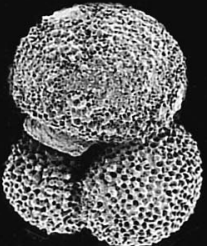

18
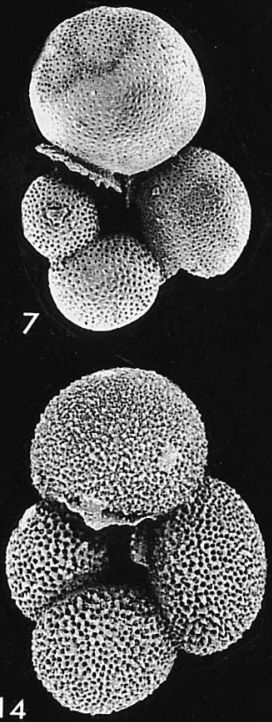

14

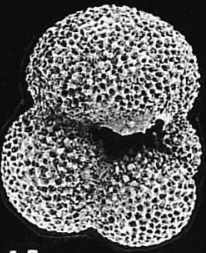

15

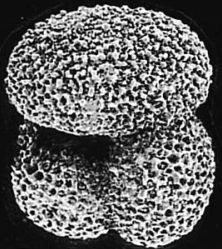


Thierstein (1981) later used this record to discuss the circumstances associated with the end Cretaceous extinctions and early Paleocene recovery.

The calcareous nannofossil distribution (Figs. 2 and 4; Table 2) in the Paleocene oozes recovered from Site 384 has been reinvestigated in order to establish first order correlations between the calcareous nannofossil datums and the magnetic reversal pattern, as well as with the planktonic foraminiferal biostratigraphy (Figs. 2 and 3). The results presented here are essentially in agreement with Okada and Thierstein's biozonal subdivision (except for the location in the core of the NP4/NP5 zonal boundary; Table 2), although they do not support their conclusion regarding the continuity of deposition across the $\mathrm{K} / \mathrm{P}$ boundary.

\section{Magnetostratigraphy}

Because of the quality of its biostratigraphy we have undertaken a magnetostratigraphic investigation of the entire Paleocene section recovered from DSDP Site 384 with a view to establishing a robust magnetobiochronology. Previously, Larson and Opdyke (1979) focused their attention on the interval 155 to $179 \mathrm{mbsf}$ (lower Paleocene and upper Cretaceous) and conducted very detailed sampling ( $\sim 10 \mathrm{~cm}$ intervals) to address issues in global correlation of $\mathrm{K} / \mathrm{P}$ boundary sections. Because the part of the core they studied was not available to us for much further sampling over the same interval, our magnetostratigraphic record and that of Larson and Opdyke (1979) should be seen as complementary.

\section{PLATE I}

All illustrations in Plates I-VI are hypotypes from DSDP Leg 43, Site 384.

1, 2. Globoconusa daubjergensis (Brönnimann) 1952. 12-3, 136-38 cm (Zone P1c; lower Paleocene, middle Danian Stage).

1. Umbilical view, $\times 300$.

2. Microstructure detail of $1, \times 1800$. Note microperforate wall and pustulose ornament.

3, 4. Globoconusa daubjergensis (Brönniman) 1952. 11-4, 136-138 cm (Zone P1c; lower Paleocene; middle Danian Stage).

3. Umbilical view, $\times 600$.

4. Microstructure detail of $1, \times 2000$. Note microperforate wall and pustulose ornament.

5, 6. Eoglobigerina eobulloides Morozova 1959. 13-1, 136-138 cm (Zone P1b; lower Paleocene; middle Danian Stage).

5. Umbilical view, $\times 200$.

6. Microstructure detail of $5, \times 2500$. Note (moderately recrystallized) cancellate wall surface and spine holes at confluence of ridges.

7. Eoglobigerina eobulloides Morozova 1959. 12-CC (Zone P1b; lower Paleocene; lower Danian Stage).

8-10. Eoglobigerina edita (Subbotina) 1953. 13-1, 136-138 cm.

8. Umbilical view, $\times 100$.

9. Spiral view, $\times 100$

10. Microstructure detail of 9 . Spine holes obscured by recrystallization.

11, 12. Subbotina triloculinoides (Plummer), 1926. 7-1, 60-62 cm (Zone P4b; upper Paleocene; mid-Thanetian Stage).

11. Umbilical view, $\times 150$.

12. Microstructure detail of $11, \times 500$. Note cancellate wall, spine holes at confluence of ridges and broad, flanging umbilical lip.

13. Subbotina triloculinoides (Plummer) 1926. 7-4, 60-62 cm (Zone P4a; upper Paleocene; lower Thanetian Stage). Umbilical view, $\times 200$.

14. Subbotina triangularis (White) 1928. 6-CC (Zone P4b; upper Paleocene; mid-Thanetian Stage). Umbilical view, $\times 150$.

15. Subbotina triangularis (White) 1928. 7-4, 60-62 cm (Zone P4; upper Paleocene; lower Thanetian Stage). Umbilical view, $\times 150$.

16. Subbotina velascoensis (Cushman), 1925. 7-1, 136-138 cm (Zone P4b; upper Paleocene; mid-Thanetian Stage). Umbilical view, $\times 150$.

17. Subbotina velascoensis (Cushman), 1925. 7-4, 60-62 cm (Zone P4a; upper Paleocene; lower Thanetian Stage). Umbilical view, $\times 200$.

18. Subbotina triloculinoides (Plummer), 1926. 10-3, 136-138 cm (Zone P3a; middle Paleocene; lower Selandian Stage). Umbilical view, $\times 200$. 
PLATE II

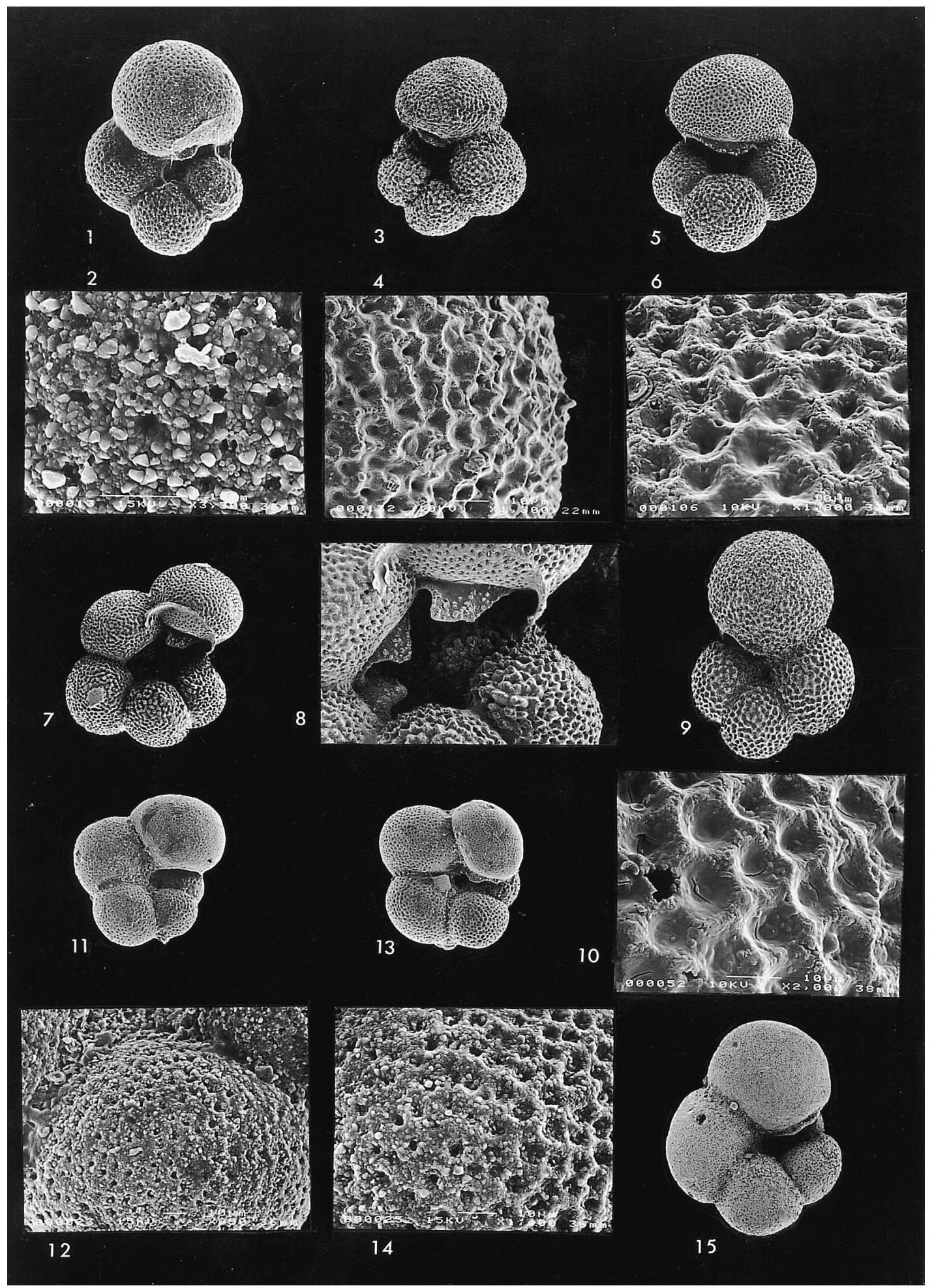




\subsection{Analysis}

We sampled the Paleocene nannofossil chalks of Site 384 for magnetostratigraphy using standard $6 \mathrm{cc}$ cubes at roughly two samples per section (from Core 4, section 1 to Core 14, section 2) for a total of 70 samples. For this study, all samples were progressively demagnetized to $50 \mathrm{mT}$ using a Schoenstedt GSD-1 alternating field (AF) induction coil. This enabled the stepwise decomposition of natural remanent magnetization to reveal the more stable component of magnetization. All measurements of magnetic remanence were made on a $2 \mathrm{G}$ cryogenic magnetometer housed within a magnetostatically-shielded laboratory at Lamont Doherty Earth Observatory with nominal internal field of $\sim 200 \mathrm{nT}$. In each sample the most stable magnetization vector was identified through analysis of demagnetization data in orthographic projection. The method of least-squares analysis (Kirschvink, 1980) was applied to the demagnetization trajectories to calculate best-fitting vectors.
An estimate of the percentage of total variance in the selected data and an intensity of the best-fit magnetization vector were also calculated and used to evaluate data reliability.

The results show that a stable magnetization can be clearly isolated in all samples from Site 384 usually in the range of either $10-50 \mathrm{mT}$ or 15 $50 \mathrm{mT}$ (Fig. 5A and B). Following the removal of a low-coercivity and downward-directed magnetization at about $10 \mathrm{mT}$, a higher-coercivity magnetization is resolved along a consistent, originbound trajectory regarded as the characteristic (ChRM) magnetization. Virtually all the samples behave in this manner and differ only in the sense of the vertical component of the ChRM magnetization, which we use to determine polarity (Site 384 cores are not oriented relative to the azimuth). Throughout the section, the lower coercivity magnetization varies in magnitude, and occasionally has sufficient strength to produce a composite natural remanent magnetization with a polarity opposite to that of the underlying ChRM magne-

\section{PLATE II}

1, 2. Parasubbotina pseudobulloides (Plummer), 1926. 13-3, 10-12 cm (Zone P1a; lower Paleocene; lower Danian Stage).

1. Umbilical view, $\times 350$.

2. Microstructure detail of $1, \times 3300$. Recrystallization has obscured spine holes.

3, 4. Parasubbotina pseudobulloides (Plummer), 1926. 12-1, 90-92 cm (Zone P1c; lower Paleocene; mid-Danian Stage).

3. Umbilical view, $\times 300$.

4. Microstructure detail of 3, $\times 1500$. Note cancellate wall surface and spine holes at confluence of ridges.

5, 6. Parasubbotina varianta (Subbotina), 1953. 11-1, 86-88 cm (Zone P3a; middle Paleocene; lower Selandian Stage).

5. Umbilical view, $\times 150$.

6. Microstructure detail of $5, \times 1800$. Note cancellate surface and spine holes at confluence of ridges, partially obscured by recrystallization.

7, 8. Parasubbotina variospira (Belford), 1984. 11-1, 86-88 cm (Zone P3a; middle Paleocene; lower Selandian Stage).

7. Umbilical view, $\times 140$.

8. Detail of umbilical area, $\times 330$. Note distinctly cancellate surface and pronounced circumumbilical, apertural flangelike lips.

9, 10. Parasubbotina varianta (Subbotina), 1953. 9-2, 136-138 cm (Zone P4a; middle Paleocene; upper Selandan Stage).

9. Umbilical view, $\times 200$.

10. Microstructure detail of $9, \times 2000$. Note cancellate wall surface and spine holes at confluence of ridges; details obscured by tragacanth glue.

11, 12. Globanomalina planocompressa (Shutskaya), 1965. 13-2, 49-51 cm (Zone P1a; lower Paleocene; lower Danian Stage).

11. Umbilical view, $\times 200$.

12. Microstructure detail of $11, \times 850$. Note smooth (non-cancellate), non-spinose wall, finely perforate test surface.

13, 14. Globanomalina planocompressa (Shutskaya), 1965. 13-1, 136-138 cm (Zone P1b; lower Paleocene; lower Danian Stage).

13. Umbilical view, $\times 200$.

14. Microstructure detail of $13, \times 1400$. Note non-spinose surface.

15. Globanomalina compressa (Plummer), 1926. 12-3: 136-138 cm (Zone P1c; lower Paleocene; middle Danian Stage). 
PLATE III
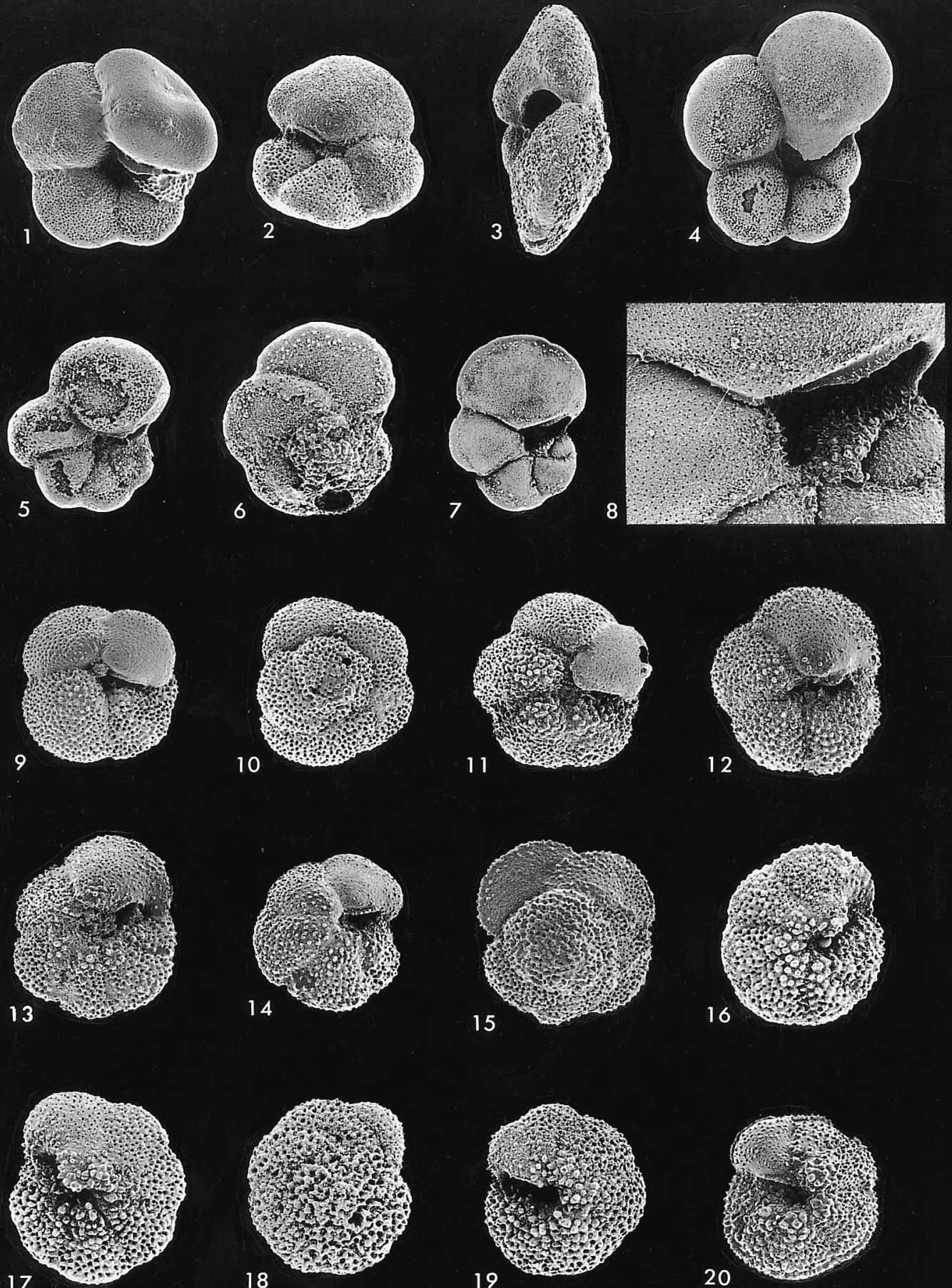
tization that we assume was acquired close to the time of deposition. The mean ChRM inclination $\left( \pm 48^{\circ}\right)$ is somewhat shallower than the dipole field inclination for the site $\left( \pm 59.5^{\circ}\right)$ but is reasonably close to the inclination $\left( \pm 55^{\circ}\right)$ expected from the Paleogene paleomagnetic field for North America (e.g. Van der Voo, 1990). The data thus suggest a relatively stable and consistent Paleocene magnetization of Site 384 (Table 3).

The resultant magnetostratigraphy at Site 384 (Fig. 2) yields well-defined intervals of field polarity over the Paleocene part of the section (from Core 6 at 99 mbsf to the base of Core 12 at 165 mbsf), except for its lowermost part (in Core 13, below $167 \mathrm{mbsf}$ ). Our sample coverage is scanty below this level down to $173 \mathrm{mbsf}$ in the upper Maastrichtian, and in particular across the $\mathrm{K} / \mathrm{P}$ boundary at $167.93 \mathrm{mbsf}$ in Core 13 which was not available for much further sampling. As our data agree well with those previously obtained by Larson and Opdyke (1979) in the interval of appreciable data overlap in Core 12 (between 156 and $\sim 165 \mathrm{mbsf}$ ), we rely on these authors' more detailed delineation of the position of the polarity changes below 156 mbsf in Cores 12 and 13, and the upper part of Core 14 (Fig. 6). In an unrelated study, an attempt was made in 1987 by one of us (DVK) to remeasure 12 of the samples from Core 13 that were used by Larson and Opdyke (1979) and still available at the East Coast Repository of

\section{PLATE III}

1. Globanomalina compressa (Plummer), 1926. 10-3: 124-126 cm (Zone P3b; middle Paleocene; mid-Selandian Stage). Umbilical view, $\times 200$.

2. Globanomalina ehrenbergi (Bolli), 1957. 11-3. 136-138 cm (Zone P2; lower Paleocene; upper Danian Stage). Umbilical view, $\times 200$.

3. Globanomalina ehrenbergi (Bolli), 1957. 10-3, 124-126 cm (Zone P3b; mid-Paleocene; lower Selandian Stage). Edge view, $\times 250$.

4. Globanomalina ehrenbergi (Bolli), 1957. 9-CC (Zone P3b; middle Paleocene; mid-Selandian Stage). Umbilical view.

5. Globanomalina pseudomenardii (Bolli), 1957. 9-6, 136-138 cm (Zone P4a; middle Paleocene; mid-Selandian Stage). Umbilical view, $\times 150$.

6. Globanomalina pseudomenardii (Bolli), 1957. 8-4, 136-138 cm (Zone P4a; upper Paleocene; lower Thanetian Stage). Spiral view, $\times 200$. Note fully keeled peripheral margin.

7, 8. Globanomalina pseudomenardii (Bolli), 1957. 6-1: 30-32 cm (Zone P4c; upper Paleocene; upper Thanetian Stage).

7. Umbilical view, $\times 150$. Note fully keeled peripheral margin.

8. Detail of umbilical region; $\times 500$. Note smooth, finely perforate test.

9, 10. Igorina pusilla (Bolli), 1957. 11-1, 136-138 cm (Zone P3a; middle Paleocene; lower Selandian Stage).

9. Umbilical view, $\times 250$.

10. Spiral view, $\times 250$. Note normal perforate, non-keeled test and weakly to moderately muricate wall.

11, 12. Igorina pusilla (Bolli), 1957. 10-6, 136-138 cm (Zone P3a; middle Paleocene; lower Selandian Stage).

11. Umbilical view, $\times 250$

12. Umbilical view, $\times 200$. Note weakly to moderately muricate, non-keeled test.

13. Igorina sp. aff. I. albeari (Cushman and Bermudez), 1949. 10-5, 10-12 cm (Zone P3a; middle Paleocene; lower Selandian Stage). Umbilical view, $\times 250$. Note partially to ?fully keeled periphery and distinctly muricate test.

14, 15. Igorina albeari (Cushman and Bermudez), 1949. 10-3, 136-138 cm (Zone P3b; middle Paleocene; mid-Selandian Stage).

14. Umbilical view, $\times 250$.

15. Spiral view, $\times 250$. Note convex (inflated) preantepenultimate whorls and fully muricate keeled peripheral margin.

16. Igorina albeari (Cushman and Bermudez), 1949. 9-2, 136-138 cm (Zone P4a; middle Paleocene; upper Selandian Stage). Umbilical view, $\times 250$. Note densely muricate, fully keeled test.

17. Igorina convexa (Subbotina), 1953. 7-1, 60-62 cm (Zone P4b; upper Paleocene; mid-Thanetian Stage). Umbilical view, $\times 250$. Note densely muricate ('granulose'), non-carinate test.

18, 19. Igorina tajikistanensis (Bykova), 1953. 6-1, 43-45 cm (Zone P4c; upper Paleocene; upper Thanetian Stage).

18. Spiral view, $\times 300$.

19. Umbilical view, $\times 300$. Note densely muricate surface and non-keeled peripheral margin.

20. Igorina trichotrocha (Loeblich and Tappan), 1957. 9-2, 136-138 cm (Zone P4a; middle Paleocene; upper Thanetian Stage). Umbilical view, $\times 200$. Note densely muricate surface and weakly muricocarinate peripheral margin. 
PLATE IV

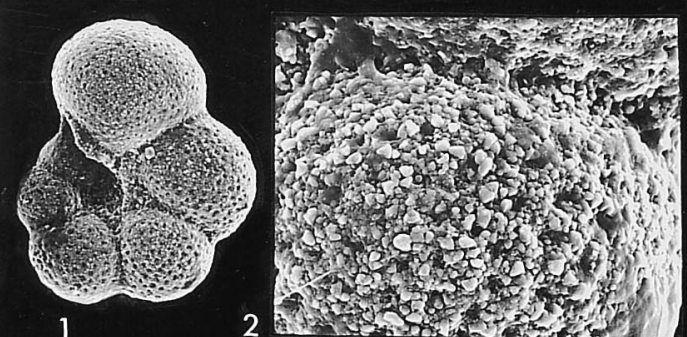

1
2

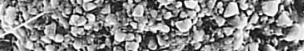

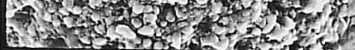

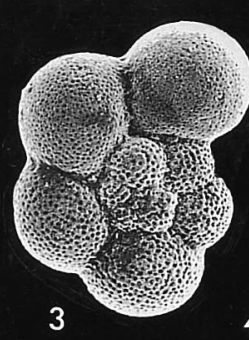

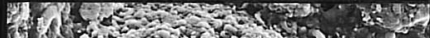

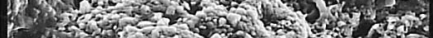

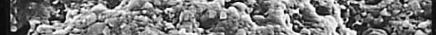

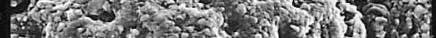

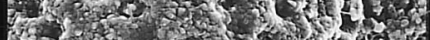
T3. $\sin$ -

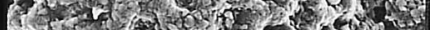

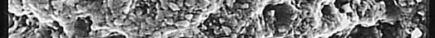

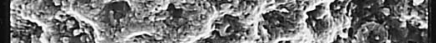
I

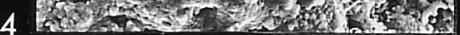

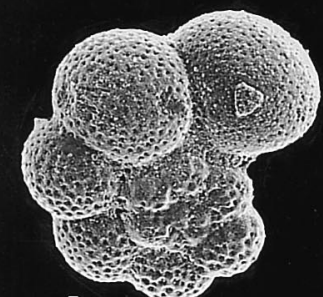

5

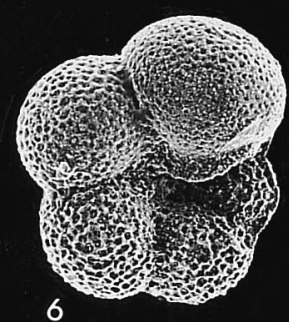

6

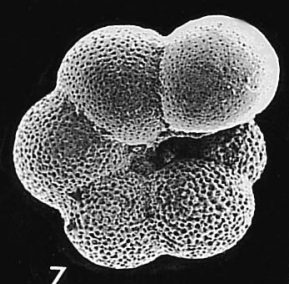

7

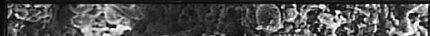

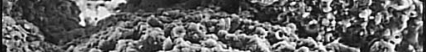

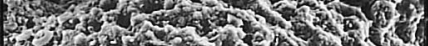

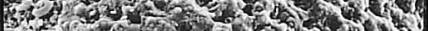
17, 2 \%

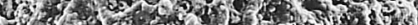

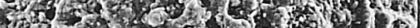

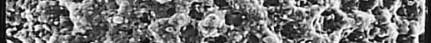

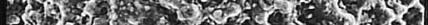

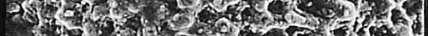

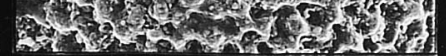
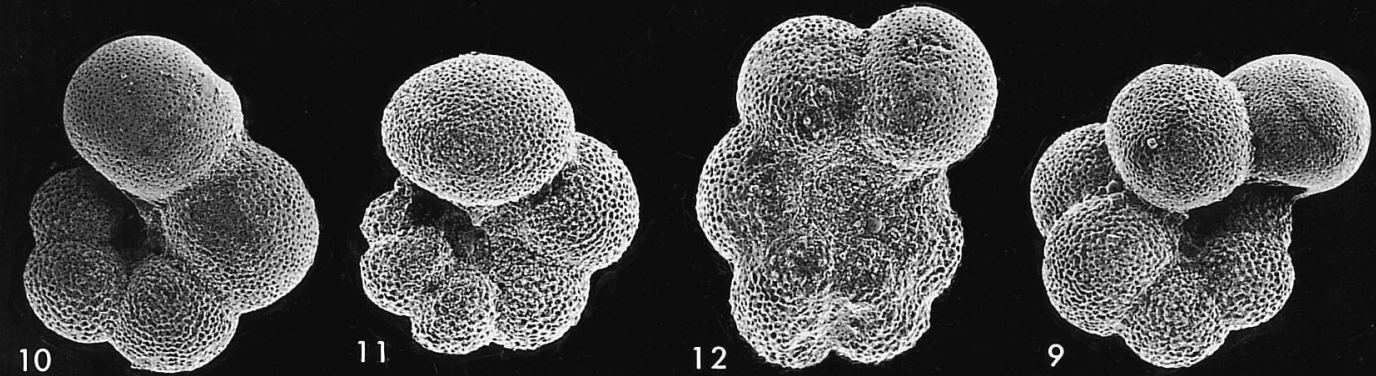

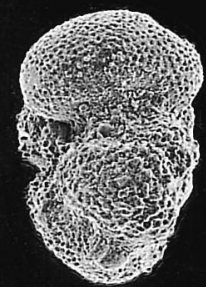

13
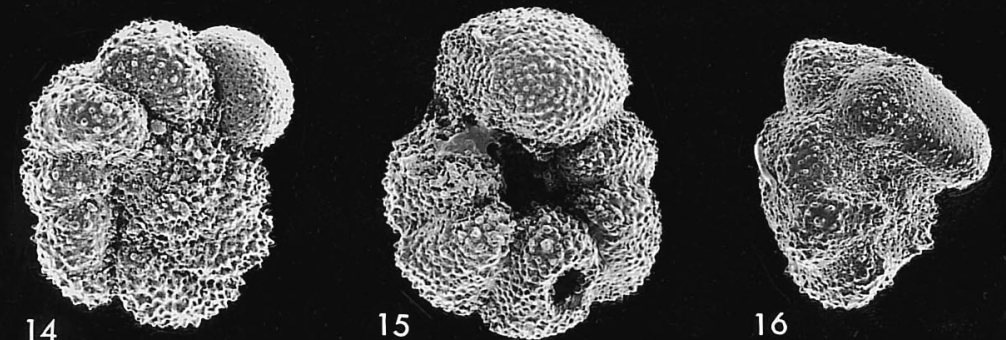
ODP. The remeasured samples were weakly magnetized and with their uncertain history, it was not possible to obtain reliable additional paleomagnetic information. Larson and Opdyke (1979) show a thin normal polarity interval at the top of Core 12 (between $\sim 155.60$ and $155.96 \mathrm{mbsf}$ ). Although we have not analyzed samples from this interval, we question its significance and suggest that this results from remagnetization as often occurs at the top of cores.

\subsection{Interpretation}

The polarity record at Site 384 from 99 mbsf to 165 mbsf compares well with what would be expected from a continuous and nearly complete Paleocene stratigraphic section and with published GPTSs (e.g. Berggren et al., 1985; CK92, 95; BKSA95). We have identified eight reversal boundaries in the Paleocene part of the section. We interpret them to correspond to all reversals between the Chron C29n/C28r and the Chron
C25n/C26r reversals (Table 4). Most of these boundaries have been resolved to within less than $0.5 \mathrm{~m}$.

Based on paleontological data [see Larson and Opdyke (1979) and Appendix 1], we are also confident that the two normal polarity magnetozones in the upper part of the Maastrichtian section represent Chrons C30n and C31n (partim) as identified by Larson and Opdyke (1979).

Larson and Opdyke (1979) identified a reversed polarity interval between $\sim 168.10$ and $\sim 169.05$ mbsf, and interpreted it as Chron C29r. We have an apparently conflicting observation of stable normal polarity magnetization in a single sample at $168.27 \mathrm{~m}(13-3,67 \mathrm{~cm}$; Table 3) whose significance we question for two reasons. First, Larson and Opdyke (1979) remarked that due to wide scatter in the inclinations the interpretation of the magnetization in the interval 166 and $171.5 \mathrm{~m}$ is difficult. Second, based on correlation between lithologies above and below the $\mathrm{K} / \mathrm{P}$ contact at $167.93 \mathrm{mbsf}$ and on quantitative analysis

\section{PLATE IV}

1,2. Praemurica taurica (Morozva), 1961. 13-3, 10-12 cm (Zone Pla; lower Paleocene; lower Danian Stage).

1. Umbilical view, $\times 350$.

2. Microstructure detail of $1, \times 1700$. Note weakly cancellate, non-spinose wall texture.

3-5. Praemurica taurica (Morozova), 1961. 13-2, 49-51 cm (Zone P1a; lower Paleocene; lower Danian Stage).

$3 . \quad$ Spiral view, $\times 180$.

4. Microstructure detail of $3, \times 1200$. Note weakly cancellate, non-spinose wall texture.

5. Spiral view, $\times 350$.

6. Praemurica pseudoinconstans (Blow), 1979. 13-3, 10-12 cm (Zone P1a; lower Paleocene; lower Danian Stage). Umbilical view, $\times 350$.

7-9. Praemurica pseudoinconstans (Blow), 1979. 13-1, 136-138 cm (Zone P1b; lower Paleocene; lower Danian Stage).

7. Umbilical view, $\times 200$.

8. $\quad$ Microstructure detail of $7, \times 850$. Note cancellate, non-spinose wall texture.

9. Umbilical view, $\times 200$. Note aberrant antepenultimate chamber.

10, 11. Praemurica inconstans (Subbotina), 1953. 12-3, 136-138 cm (Zone P1c; lower Paleocene; middle Danan Stage).

10. Umbilical view, $\times 200$.

11. Umbilical view, $\times 200$. Note weakly incised intercameral sutures.

12, 13. Praemurica uncinata (Bolli), 1957. 11-3, 136-138 cm (Zone P2; lower Paleocene; upper Danian Stage).

12. Umbilical view, $\times 200$. Note anguloconical chambers in early part of final whorl followed by rounded chambers in terminal part.

13. Edge view, $\times 200$. Note absence of peripheral muricocarina.

14, 15. Praemurica uncinata (Bolli), 1957. 11-3, 30-32 cm (Zone P2; lower Paleocene; upper Danian Stage).

14. Spiral view, $\times 150$. Note tangentially disposed intercameral sutures in first half of final whorl followed by weakly curved, radial disposition in second half and reduction in muricae in later (younger) chambers.

15. Umbilical view, $\times 150$. Note strongly incised intercameral sutures and triangular shaped chambers.

16. Morozovella praeangulata (Blow), 1979. 11-3, 136-138 cm (Zone P2; lower Paleocene; upper Danian Stage). Edge view, $\times 200$. Note anguloconical profile and absence of muricocarina. 


\section{PLATE V}

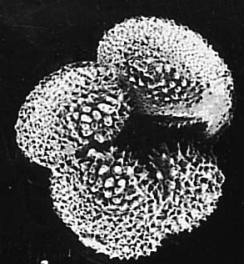

1

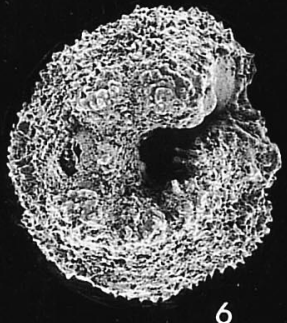

6
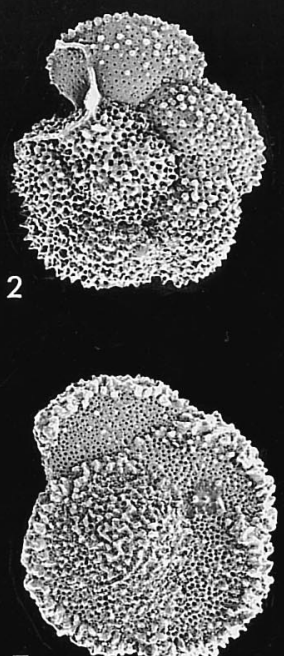

7

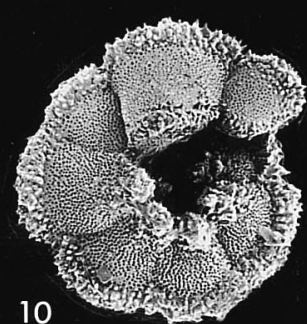

10

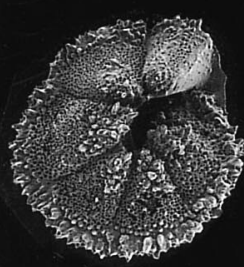

9
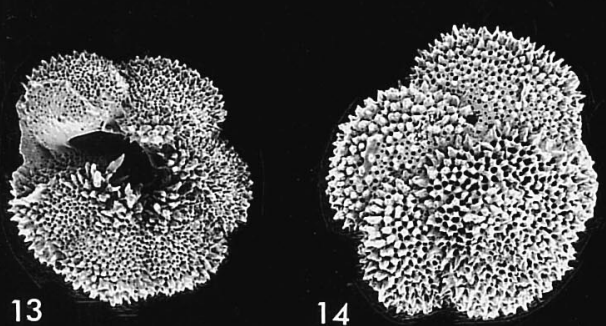

13

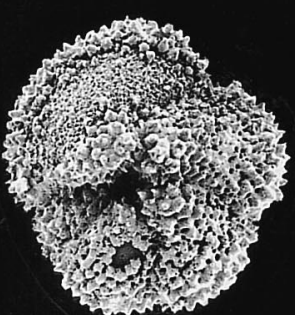

18

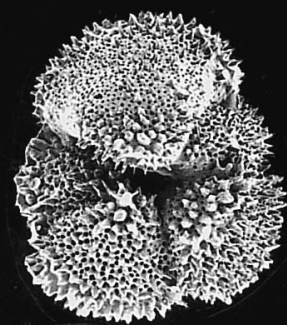

19
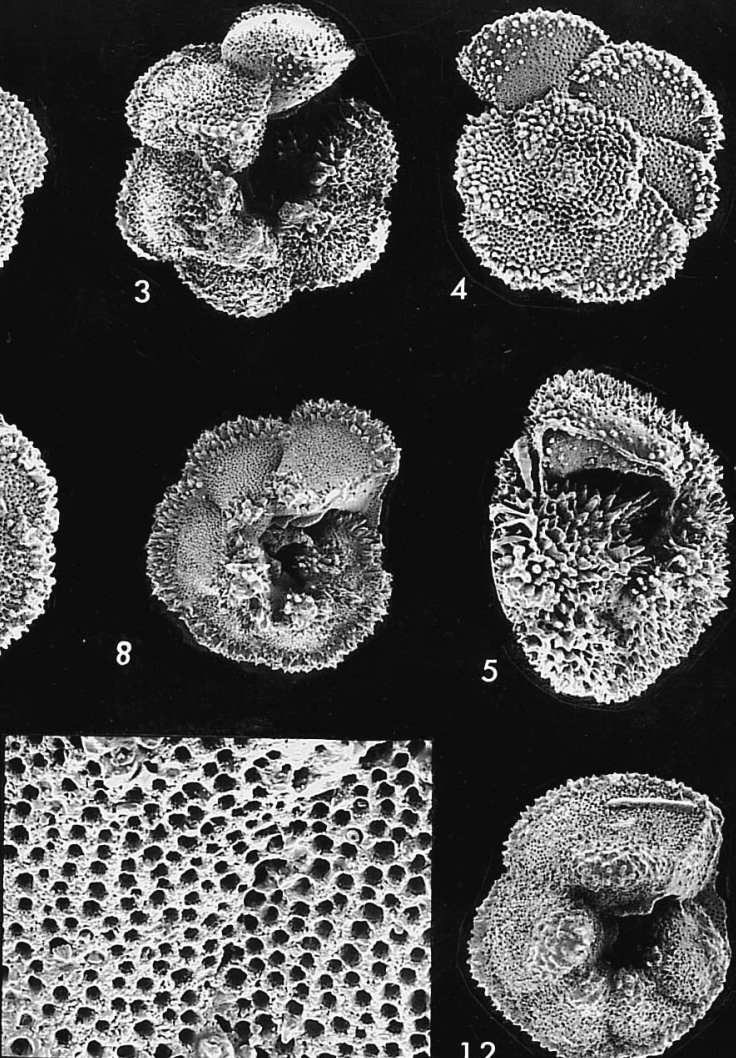

12
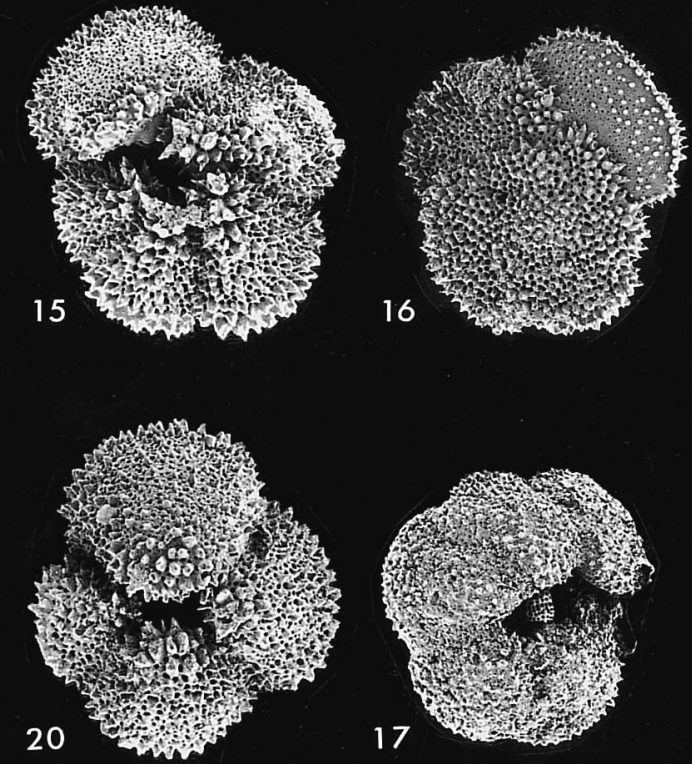
of calcareous nannofossil assemblages, Thierstein and Okada (1979) concluded that drilling disturbance affected the boundary interval, with Danian sediments incorporated into the Maastrichtian chalk. Because we cannot exclude the possibility that normal polarity at $168.27 \mathrm{mbsf}$ was acquired in a secondary manner, and because our lone sample data compare poorly with the suite of samples analyzed by Larson and Opdyke (1979), we accept these authors' delineation of a $\sim 1 \mathrm{~m}$ interval of reversed polarity between 168.10 and $\sim 169.05$ mbsf and its identification as Chron C29r (based on supporting paleontologic evidence, see Appendix 1).

The significance of the normal polarity interval between the top of Core $13(\sim 166 \mathrm{mbsf})$ and $\sim 168.10$ mbsf remains unresolved, and we contribute no new data here. Larson and Opdyke (1979) interpreted it as part of the magnetozone that begins at $162.58 \mathrm{mbsf}$ in Core 12 and identified it as Chron C29n. In addition to the poor quality of the magnetization noted by these authors, there are several problems. First, the $\mathrm{K} / \mathrm{P}$ contact falls in the lowermost part of this normal polarity

\section{PLATE V}

1, 2. Morozovella angulata (White), 1928. 11-1, 86-88 cm (Zone P3a; middle Paleocene; lower Selandian Stage).

1. Umbilical view, $\times 160$. Note development of muricae around umbilicus.

2. Spiral view, $\times 200$. Note progressive reduction in cancellate wall texture and development of peripheral muricocarina.

3, 4. Morozovella conicotruncata (Subbotina), 1953. 10-3, 10-12 cm (Zone P3b; middle Paleocene; middle Selandian Stage).

3. Umbilical view, $\times 150$. Compare with 1 .

4. Spiral view, $\times 150$. Compare with 2 .

5. Morozovella conicotruncata (Bolli), 1957. 9-CC (Zone P3b; middle Paleocene; middle Selandian Stage). Edge view, $\times 200$. Note strong murical development in umbilical region.

6, 7. Morozovella velascoensis (Cushman), 1925. 9-6, 136-138 cm (Zone P4a; middle Paleocene; middle Selandian Stage).

6. Umbilical view, $\times 180$.

7. Spiral view, $\times 180$.

8. Morozovella velascoensis (Cushman), 1925. 6-1, 30-32 cm (Zone P4c; upper Paleocene; upper Thanetian Stage). Umbilical view, $\times 120$. Note strongly developed peripheral muricocarina and circumumbilical muricae.

9. Morozovella occlusa (Loeblich and Tappan), 1957. 6-1, 30-32 cm (Zone P4c; upper Paleocene; upper Thanetian Stage). Umbilical view, $\times 120$. Note low conical test and narrow umbilicus.

10, 11. Morozovella pasionensis (Bermudez), 1961. 6-1, 30-32 cm (Zone P4c; upper Paleocene; upper Thanetian Stage).

10. Umbilical view, $\times 120$.

11. Microstructure detail of 10 .

12. Morozovella acuta (Toulmin), 1941. 7-3, 92-94 cm (Zone P4b; middle Paleocene; upper Selandian Stage). Umbilical view, $\times 150$.

13, 14. Morozovella apanthesma (Loeblich and Tappan), 1957. 7-CC (Zone P4a; upper Paleocene; lower Thanetian Stage).

13. Umbilical view, $\times 120$.

14. Spiral view, $\times 200$. Note strongly muricate surface.

15, 16. Morozovella apanthesma (Loeblich and Tappan), 1957. 6-1, 130-132 cm (Zone P4c; upper Paleocene; upper Thanetian Stage).

15. Umbilical view, $\times 120$. Note strongly muricate peripheral margin.

16. Spiral view, $\times 130$.

17. Morozovella apanthesma (Loeblich and Tappan), 1957. 10-3, 124-126 cm (Zone P3b; middle Paleocene; lower Selandian Stage). Umbilical view, $\times 150$. Somewhat corroded specimen showing concentration of blunt ends of muricae along peripheral margin.

18. Morozovella aequa (Cushmana dn Renz), 1942. 6-1, 130-132 cm (Zone P4c; upper Paleocene; upper Thanetian Sage). Umbilical view, $\times 150$.

19, 20. Morozovella aequa (Cushman and Renz), 1942. 6-1, 43-45 cm (Zone P4c; upper Paleocene; upper Thanetian Stage).

19 Umbilical view, $\times 150$.

20. Umbilical view, $\times 120$. Note/compare variable development/disposition of muricae on test chambers and periphery in 18,19 and 20 . 


\section{PLATE VI}

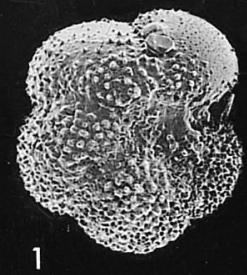

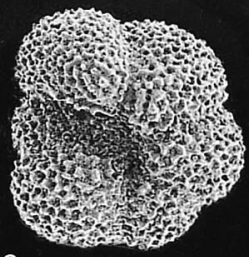

2

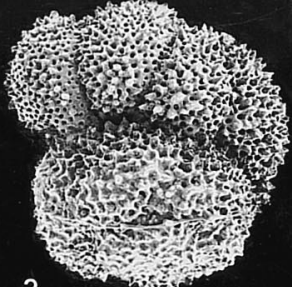

3

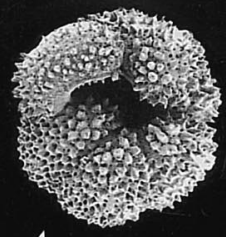

4

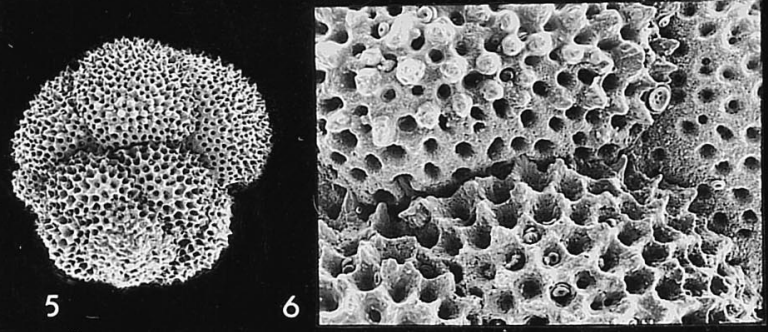

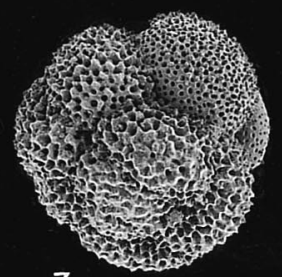

7

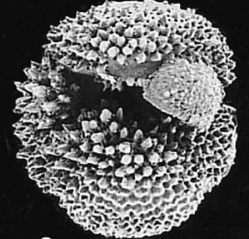

8
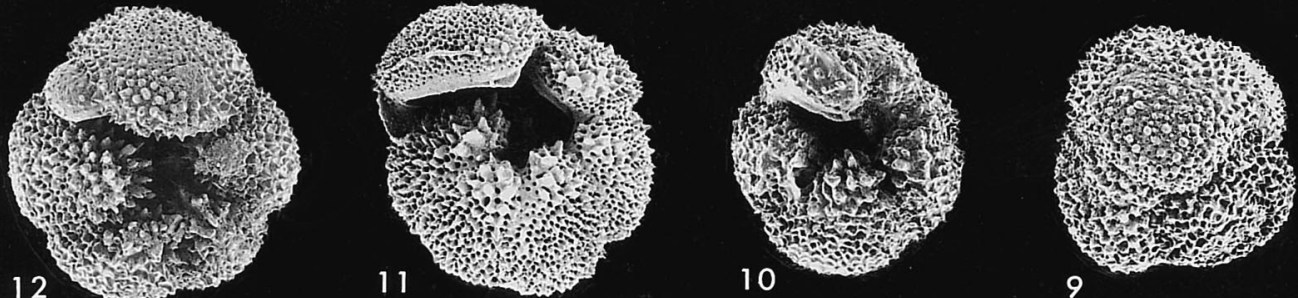

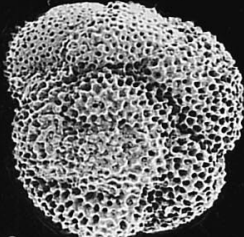

13

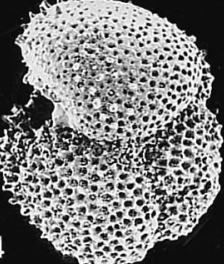

14
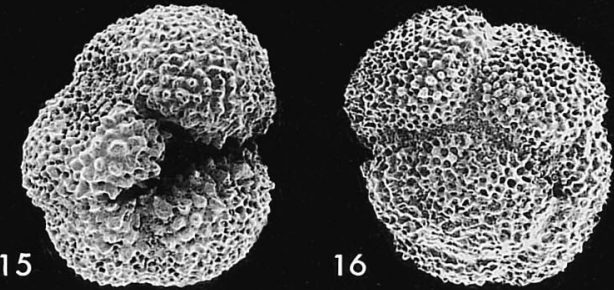

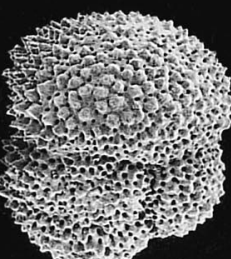

19

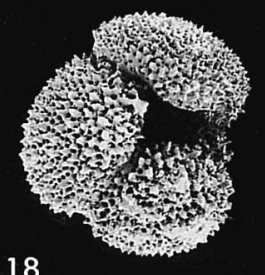

18

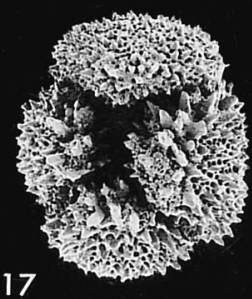


interval. Second, there is a $2 \mathrm{~m}$ recovery gap between Cores 12 and 13 .

Thierstein and Okada (1979) and Thierstein (1981) proposed that the $\mathrm{K} / \mathrm{P}$ boundary falls in a normal polarity chron that was not identified in the Gubbio section. This was based on magnetobiostratigraphic correlations in other sections, relationships between widths of magnetic anomalies on the sea-floor and thicknesses of the corresponding magnetozones in several stratigraphic sections, and magnetostratigraphic investigations in terrestrial sections. Their evidence from the terrestrial record has been rejected (see discussion in Berggren et al., 1985) and it is now firmly established that the $\mathrm{K} / \mathrm{P}$ boundary occurred in the mid part of
Chron C29r (e.g. Lowrie and Alvarez, 1977; Roggenthen and Napoleone, 1977). In contrast to the general belief of Leg 43 participants (see papers in Tucholke et al., 1979), Larson and Opdyke (1979) proposed that the K/P contact in Hole 384 is unconformable. If correct and if the normal magnetozone between 166 and $168.10 \mathrm{mbsf}$ has significance (i.e. is not an artifact of overprinting), this latter must represent the concatenation (at 167.93 mbsf) of Chrons C29n and C30n. This is clearly unacceptable because Chron C30n is represented below $\sim 169.05$ mbsf. The obvious interpretation is that the $17 \mathrm{~cm}$ thick interval of normal polarity between 167.93 and $168.10 \mathrm{mbsf}$ results from overprinting. This might lead us to question

\section{PLATE VI}

1. Acarinina strabocella (Loeblich and Tappan), 1957. 10-4, 136-138 cm (Zone P3a; middle Paleocene; lower Selandian Stage). Umbilical view, $\times 250$.

2. Acarinina strabocella (Loeblich and Tappan), 1957. 9-2, 136-138 cm (Zone P4a; middle Paleocene; upper Selandian Stage). Umbilical view, $\times 300$. Note involute coiling and distinctly muricate, non-spinose wall texture.

3. Acarinina subsphaerica (Subbotina), 1947. 8-1, 136-138 cm (Zone P4a; upper Paleocene; lower Thanetian Stage). Spiral view, $\times 200$. Note high conical spire and densely muricate test surface.

4-6. Acarinina subsphaerica (Subbotina), 1947. 7-CC (Zone P4a; upper Paleocene; lower Thanetian Stage).

4. Umbilical view, $\times 200$.

5. $\quad$ Spiral view, $\times 200$. Compare with 3 .

6. Microstructure detail of 5, $\times 700$. Note normal perforate, non-spinose, muricate test surface

7. Acarinina subsphaerica (Subbotina), 1947. 7-4, 136-138 cm (Zone P4a; upper Paleocene; lower Thanetian Stage). Spiral view, $\times 200$.

8, 9. Acarinina nitida (Martin), 1943. 7-CC (Zone P4a; upper Paleocene; lower Thanetian Stage). 8. Umbilical view, $\times 200$.

9. Umbilical view, $\times 200$.

10. Acarinina nitida (Martin), 1943. 7-1, 60-62 cm (Zone P4b; upper Paleocene; middle Thanetian Stage). Umbilical view, $\times 200$.

11. Acarinina mckannai (White), 1928. 7-CC (Zone P4a; upper Paleocene; lower Thanetian Stage). Umbilical view, $\times 200$. Note dense concentration of large muricae around umbilical region.

12, 13. Acarinina mckannai (White), 1928. 7-1, 60-62 cm (Zone P4b; upper Paleocene; middle Thanetian Stage).

12. Umbilical view, $\times 200$.

13. Spiral view, $\times 200$. Compare disposition/shape of chambers and intercameral sutures in A. subsphaerica in 3 and 5 .

14. Acarinina mckannai (White), 1928. 7-2, 106-108 cm (Zone P4b; upper Paleocene; middle Thanetian Stage). Edge view, $\times 200$.

15. Acarinina soldadoensis (Brönniman), 1952. 8-3, 92-94 cm (Zone P4c; upper Paleocene; upper Thanetian Stage). Umbilical view, $\times 200$.

16. Acarinina soldadoensis (Brönniman), 1952. 6-2, 105-107 cm (Zone P4c; upper Paleocene; upper Thanetian Stage). Spiral view, $\times 200$. Compare chamber shape/disposition and intercameral sutures in A. mckannai in 13 .

17. Acarinina soldadoensis (Brönniman), 1952. 6-1, 89-91 cm (Zone P4c; upper Paleocene; upper Thanetian Stage). Umbilical view, $\times 200$. Note dense, thick muricae.

18. Acarinina coalingensis (Cushman and Hanna), 1927. 6-1, 89-91 cm (Zone P4c; upper Paleocene; upper Thanetian Stage). Umbilical view, $\times 200$.

19, 20. Acarinina coalingensis (Cushman and Hanna), 1927. 6-1, 30-32 cm (Zone P4c; upper Paleocene; upper Thanetian Stage).

19. Spiral view, $\times 200$.

20. Umbilical view, $\times 250$. Note thick, blunt ('knobby') and densely distributed muricae typical of this taxon. 


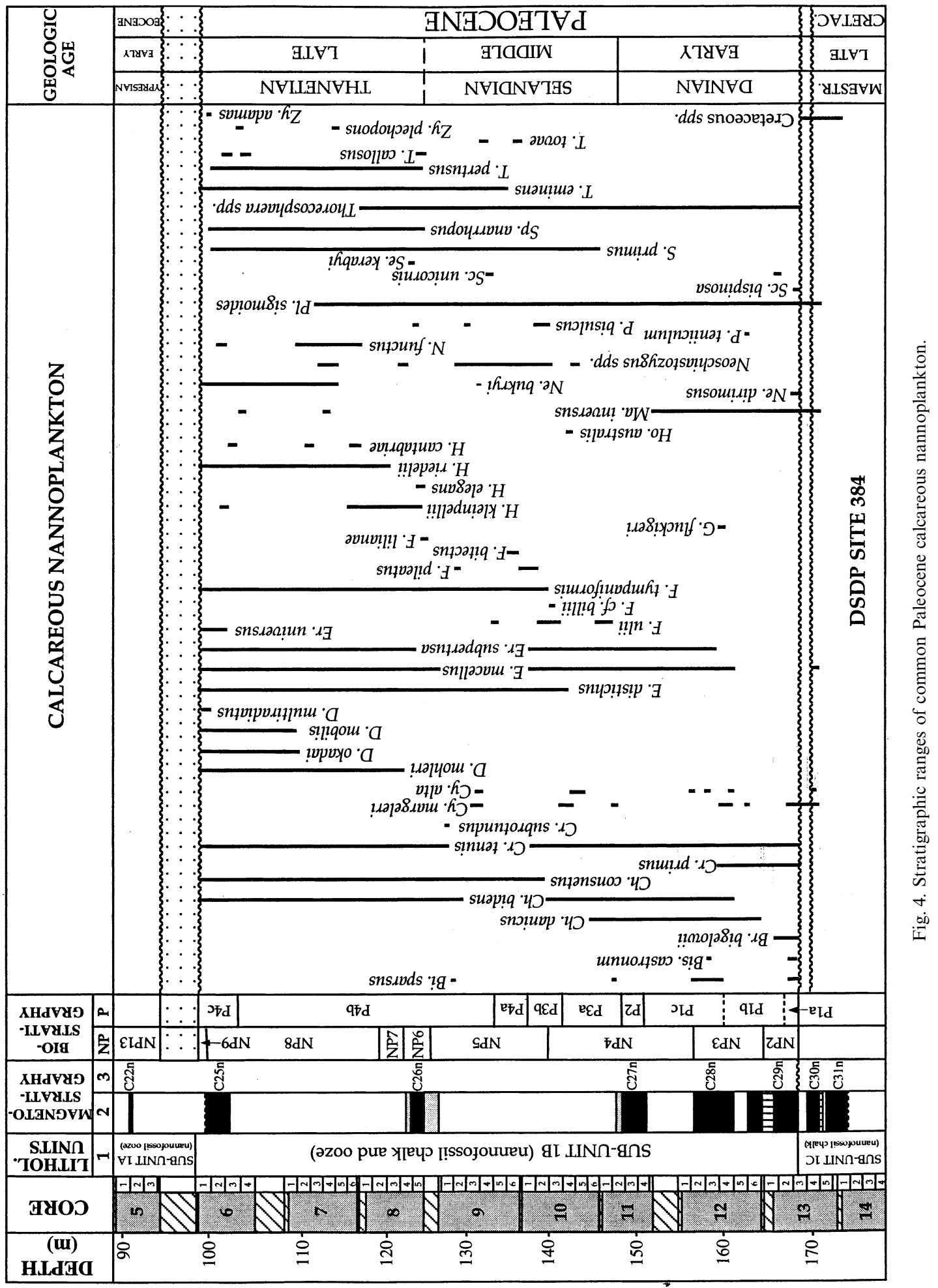


Table 2

Paleocene calcareous plankton datum events/zonal boundaries delineated in DSDP Hole 384 as inferred from the integration of the data of Okada and Thierstein (1979) with this study. In this study, the zonal boundaries are located at the LO or HO of the zonal markers, independent of their frequency. Although in the text Okada and Thierstein (1979) indicated that they relied on the HOs and LOs of markers to delineate zonal boundaries, location of these latter in their range chart (their table 3B) does not follow from this. This table gives the actual LOs and HOs of marker species given by Okada and Thierstein. Significant discrepancies in their data occur for the NP4/NP5 zonal boundary, located between samples 10-3, 49-50 and 10-2, 119-120, whereas the LO of $F$. tympaniformis is shown between 10-5, 54-55 and 10-4, 55-56. The former position is consistent with the data presented here. Lesser discrepancies include the delineation of the NP6/NP7 zonal boundary between 8-3, 124-125 and 8-4, 49-50 with respect to the LO of D. mohleri, and that of the Discoaster nobilis Zone (Zone CP7 of Okada and Bukry, 1980=upper Zone NP8) between 7-5, 5960 and 7-6, 49-50 compared to the LO of D. nobilis between 7-6, 109-110 and 7-CC

\begin{tabular}{lllll}
\hline Biozonal boundaries & Zonal marker & Okada and Thierstein (1979) & Aubry (this work) & Location in core \\
\hline NP9 & LO D. multiradiatus & $6-1,109-110$ & $6-1,132-135$ & $6-1,132-135$ \\
NP8 & LO H. riedelii & $6-1,149-150$ & $6-2,95-97$ & $6-1,149-150$ \\
& & a & $8-2,141-143$ & $8-2,141-143$ \\
NP7 & LO D. mohleri & a & $8-3,65-67$ & $8-3,65-67$ \\
& & $8-4,49-50$ & $8-4,26-28$ & $8-4,49-50$ \\
NP6 & LO H. kleinpelli & $8-4,129-130$ & $8-4,136-138$ & $8-4,129-130$ \\
& & $8-C C$ & $8-5,136-138$ & $8-C C$ \\
NP5 & LO F. tympaniformis & $9-1,4-5$ & $9-1,8-10$ & $9-1,8-10$ \\
& & $10-4,55-56$ & $10-2,73-75$ & $10-2,73-75$ \\
NP4 & LO E. macellus & $10-5,54-55$ & $10-2,136-138$ & $10-2,136-138$ \\
& & $12-2,51-52$ & $12-2,5-7$ & $12-2,51-52$ \\
NP3 & LO C. danicus & $12-2,109-110$ & $12-2,134-138$ & $12-2,109-110$ \\
& & $12-6,49-50$ & $12-6,108-110$ & $12-6,108-110$ \\
NP2 & LO C. tenuis & $12-6,109-110$ & $13-1,136-138$ & $12-6,109-110$ \\
& & $13-3,31-32$ & $13-3,10-12$ & $13-3,31-32$ \\
K & & $13-3,34$ & $13-3,99-101$ & $13-3,34$ \\
\hline
\end{tabular}

a The LO of $H$. riedelii is reported by Okada and Thierstein to be at the same level as the LO of H. kleinpelli.

whether normal polarity between 166 and $167.93 \mathrm{mbsf}$ is original or also results from overprinting. The calcareous nannofossil species Cruciplacolithus tenuis occurs immediately above 167.93 mbsf. Its first appearance datum (FAD) has been tied to early Chron C29n (see discussion below) which suggests that early Chron C29n is represented below $166 \mathrm{~m}$ (Fig. 6, compare with Fig. 2).

Second, there is a $2 \mathrm{~m}$ recovery gap between Cores 12 and 13, and it is unclear whether there was loss of sediment or whether the sediment in Core 13 should be shifted to the top of section 13-1 at $164.6 \mathrm{~m}$ (following the policy adopted by ODP subsequent to Leg 43), which would result in the $\mathrm{K} / \mathrm{P}$ contact being relocated at $166.68 \mathrm{mbsf}$. If the interval between 162.58 and $\sim 167.93$ mbsf represents Chron C29n (partim) it is abnormally thick $(5.52 \mathrm{~m})$ in comparison to the interval representing Chron C28n, implying sedimentation rates higher than for the interval above $162.58 \mathrm{mbsf}$; this is surprising considering the likely reduced earliest Paleocene productivity. Relocation of the unconformity at $166.68 \mathrm{mbsf}$ would reduce the interval representing Chron C29n (partim) to $4.10 \mathrm{~m}$.

\section{Carbon and oxygen isotope stratigraphy}

Carbon isotope stratigraphy is recognized as a powerful tool for global correlations. The use of the sharp 3 to $4 \%$ o upper Paleocene excursion to correlate upper Paleocene-lower Eocene stratigraphic records is now a familiar procedure in Paleocene investigations (e.g. Kennett and Stott, 1991; Koch et al., 1992; Pak and Miller, 1992; Zachos et al., 1994; Aubry et al., 1996; Sinha et al., 1996; but see Aubry, 1998). Similarly, a progressive increase in $\delta^{13} \mathrm{C}$ exhibited by both planktonic and benthic foraminifera has been recognized in many 

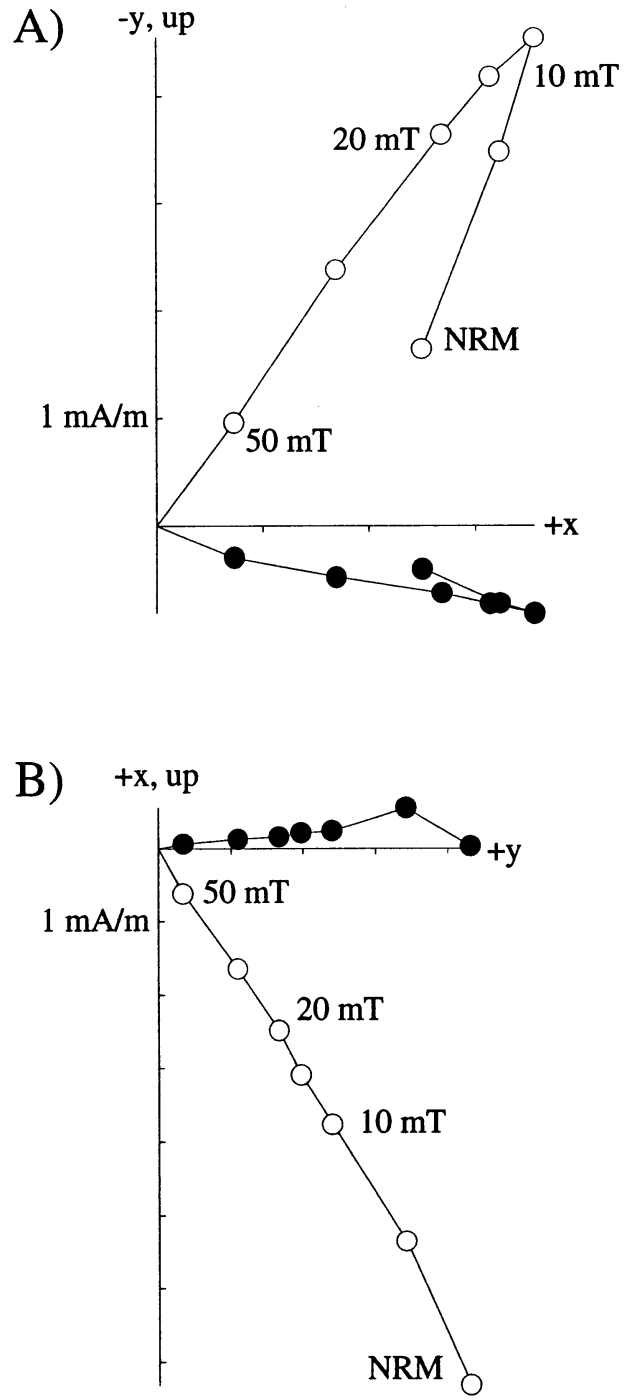

Fig. 5. Typical demagnetization profiles from Site 384 illustrating the isolation of the B-magnetization from the relatively minor overprint. (A) Sample 09-1-008 at 127.43 mbsf showing reversed polarity magnetization. (B) Sample 08-5-015 at $123.45 \mathrm{mbsf}$ showing normal polarity magnetization. AF demagnetization steps in millitesla, units of magnetization intensity milliamps/meter. Open symbols and closed symbols show vertical and horizontal projection, respectively.

upper Paleocene sections (e.g. Boersma et al., 1979; Corfield et al., 1991; Bralower et al., 1995; Corfield and Norris, 1996) as well as a long-term decrease in $\delta^{13} \mathrm{C}$ during Chron C24r (e.g. Shackleton et al., 1979; Zachos et al., 1994). For the purpose of reconstructing deep water circulation in the world ocean during the Paleocene, Corfield and Norris (1996) have established a detailed carbon isotope stratigraphy for the Paleocene of Site 384 that we elaborate on here. This $\delta^{13} \mathrm{C}$ stratigraphy is correlated to the biostratigraphy and magnetostratigraphy (Fig. 7).

Stable isotope measurements were made on fine fraction $(<38 \mu \mathrm{m})$ carbonates, as well as various monospecific species of planktonic and benthic foraminifera. Samples were analyzed in a Finningan MAT 252 mass spectrometer with associated carbonate preservation device ('Kiel Device') in the Department of Geology and Geophysics of the Woods Hole Oceanographic Institution. Six standard carbonate powders were run with each set of 40 unknowns: two each of Carrara Marble, Atlantis II deep sea coral, and B-1 marine carbonate. Corrections were made to VDPD and further correction was made to account for the predictable shift in measured isotopic ratios with decreasing sample size. The overall precision of our measurements is $\pm 0.04 \%$ o for $\delta^{13} \mathrm{C}$ and $\pm 0.08 \%$ or for $\delta^{18} \mathrm{O}$. In practice, precision is even better than this for samples larger than $\sim 40 \mu \mathrm{g}$, which approximates the minimum size for the samples reported here.

\subsection{K/P boundary stable isotopic record}

Planktonic and benthic foraminifera show a negative shift of $\sim 0.4$ to $0.6 \%$ in $\delta^{18} \mathrm{O}$ starting at the base of Magnetozone C29r (Fig. 8). There is a synchronous positive $\delta^{13} \mathrm{C}$ shift of $\sim 0.3$ to $0.5 \%$ o in benthic foraminifera and several planktonic species starting at the same level ( 169 mbsf). Notably, not all planktonic species show the $\delta^{13} \mathrm{C}$ shift; surface water species such as Rugoglobigerina rotundata at DSDP Site 384 do not appear to have displayed much change in $\delta^{13} \mathrm{C}$ during the late Maastrichtian (Fig. 8) and, in this respect, parallel the absence of any long-term trend in the surface water species, Globigerinelloides multispinatus, from the Southern Ocean (Fig. 9).

This record is similar to, albeit less expanded than, at Maud Rise Site 690. Stott and Kennett (1990) recognized a pronounced negative shift in oxygen isotopes in the lower third of Magnetozone C29r at ODP 690 in the Weddell Sea (Fig. 9). This 


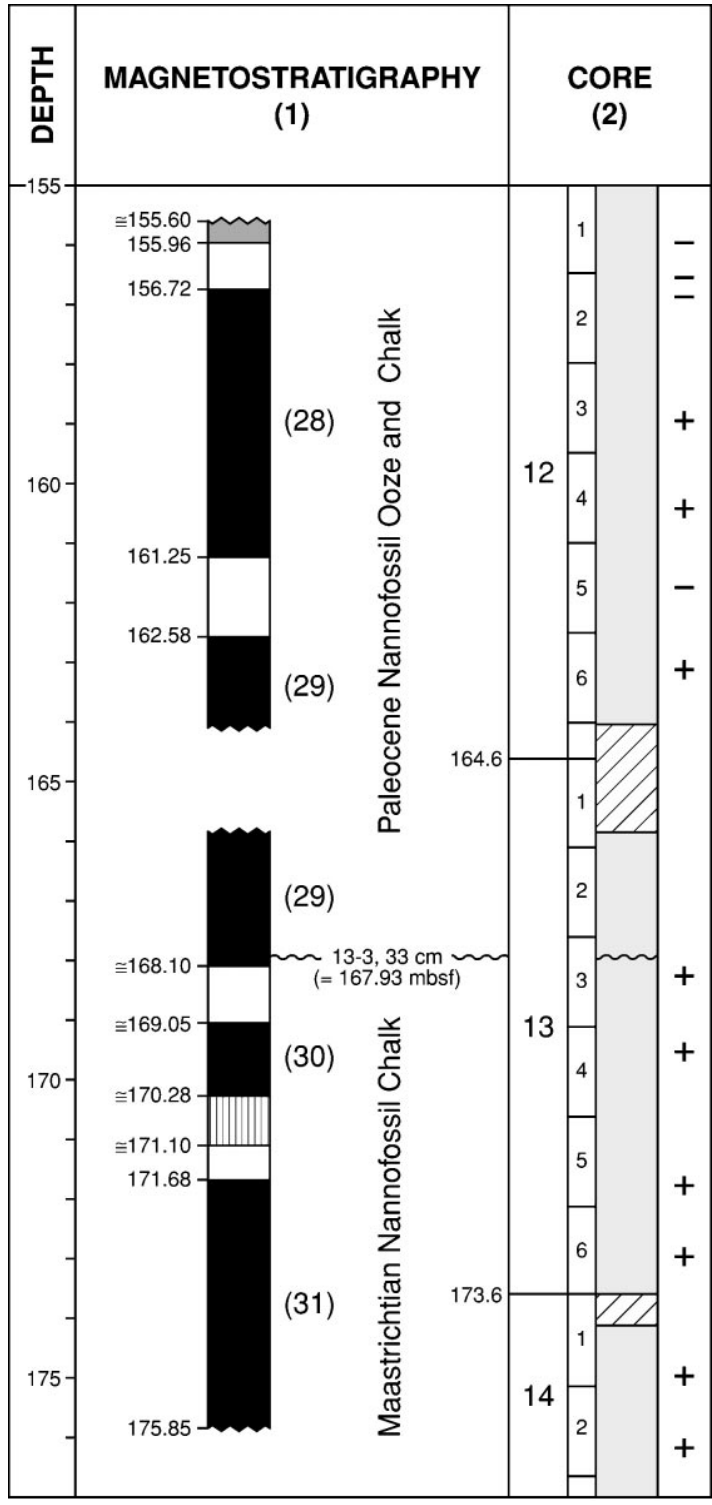

Fig. 6. Magnetostratigraphy of the interval between 155 and $176 \mathrm{mbsf}$. The few additional measurements that were possible for this study [this paper; (3) right of figure] essentially support the data presented by Larson and Opdyke [1979; (1), left of figure] below $156.72 \mathrm{mbsf}$. Note that depths given by Larson and Opdyke are averaged depths between successive samples analyzed by them whereas we show the actual levels that we have measured. This likely accounts for the slight discrepancy between the two sets of data regarding the downward extent of the upper revised magnetozone. We have measured a reversed polarity at $156.78 \mathrm{mbsf}$ whereas Larson and Opdyke approximated at $156.72 \mathrm{mbsf}$ the contact between the reversed magnetozone above and the normal magnetozone below. Because the event corresponds to a warm period about $300 \mathrm{ky}$ before the K/P boundary, which gradually decayed toward somewhat cooler temperatures at the boundary itself (Barrera, 1994; Barrera and Keller, 1994). The oxygen isotope depletion and warming are present in records from both planktonic and benthic foraminifera but the magnitude of the $\delta^{18}$ $\mathrm{O}$ shift varies from $\sim 0.3 \%$ in Heterohelix globulosa to at least $0.75 \%$ in the benthic foraminifera Nuttalides truempyi. The warm interval is accompanied by a modest $\sim 0.6 \%$ increase in $\delta^{13} \mathrm{C}$ values of benthic foraminifera which peak at the $\mathrm{K} / \mathrm{P}$ boundary (Fig. 9).

\subsection{The Paleocene stable isotope record}

The $\delta^{13} \mathrm{C}$ record of benthic foraminifera and fine fraction carbonate $(>38 \mu \mathrm{m})$ shows a modest decrease from the $\mathrm{K} / \mathrm{P}$ boundary up to the base of Magnetozone C26r (Fig. 7). This is followed by the Paleocene carbon isotope maximum - a broad rise and fall in $\delta^{13} \mathrm{C}$ values that occurred in the late Paleocene (Shackleton and Hall, 1985; Miller et al., 1987) (Fig. 7). The lower part of the Paleocene section up to the top of Magnetozone $\mathrm{C} 27 \mathrm{r}$ is characterized by relatively little carbon isotope variability which suggests that it will be difficult to achieve high resolution stratigraphic correlations in this interval based on chemostrati-

levels actually analyzed by Larson and Opdyke are not known, we approximate the location of the reversal boundary at 156.90 mbsf using Larson and Opdyke's fig. 2. The only conflicting measurement in this interval is at $168.27 \mathrm{mbsf}$ where we measured normal polarity that we interpret as reflecting overprinting (see text). However, our data do not support the delineation by Larson and Opdyke of a normal magnetozone between $\sim 155.80$ and 155.96 mbsf. (1) Larson and Opdyke (1979) gave correspondance between magnetozones and seafloor anomalies (in parenthesis). (2) From Tucholke et al. (1979). In case of no recovery in the upper part of the core, we have shifted sediments to the top of the core in agreement with Larson and Opdyke but contrary to the data as shown in the core barrels (1979, p. 138, 139). Grey pattern: sediment; hatched pattern: recovery gaps. (3) This study. Tick marks at left: location of samples analyzed. Large intervals (dotted pattern) of the core were not available to us for additional sampling. N: normal polarity; R: reversed polarity. Boundaries between magnetozones drawn to fit with Larson and Opdyke's data where appropriate. 
Table 3

Summary of progressive demagnetization data on discrete samples used in constructing magnetostratigraphy from DSDP Site 384. Samples designated in core-section level (centimeters within section) and depth in mbsf=meters below sea-floor. $N=$ number of demagnetization data used in each least-squares analysis; Var = percentage of the total variance in the selected data range accounted for by the least-squares vector; Dec, Inc=declination and inclination of the least-squares magnetization; AF1, AF2=range of AF demagnetization steps used for isolation of magnetization component; Intensity= magnitude of least-squares magnetization

\begin{tabular}{|c|c|c|c|c|c|c|c|c|}
\hline Core-section level $(\mathrm{cm})$ & Depth (mbsf) & $N$ & $\operatorname{Var}(\%)$ & $\operatorname{Dec}\left({ }^{\circ}\right)$ & $\operatorname{Inc}\left({ }^{\circ}\right)$ & $\mathrm{AF} 1(\mathrm{mT})$ & $\mathrm{AF} 2(\mathrm{mT})$ & Intensity $(\mathrm{mA} / \mathrm{m})$ \\
\hline $04-1-037$ & 80.27 & 4 & 99.7 & 50.4 & 37.2 & 15 & 50 & 2.100 \\
\hline $04-1-115$ & 81.05 & 4 & 97.5 & 188.7 & 48.6 & 15 & 50 & 0.480 \\
\hline $04-2-012$ & 81.52 & 4 & 99.2 & 225.7 & 42.7 & 15 & 50 & 0.733 \\
\hline $04-2-125$ & 82.65 & 4 & 95.6 & 79.3 & 39.3 & 15 & 50 & 0.115 \\
\hline $04-3-027$ & 83.17 & 4 & 99.5 & 21.0 & 52.1 & 15 & 50 & 2.023 \\
\hline $04-3-113$ & 84.03 & 4 & 99.5 & 6.6 & 70.7 & 15 & 50 & 1.205 \\
\hline 04-4-005 & 84.45 & 4 & 99.5 & 201.2 & 43.2 & 15 & 50 & 0.430 \\
\hline $04-4-118$ & 85.58 & 4 & 99.2 & 206.0 & 64.4 & 15 & 50 & 0.425 \\
\hline $04-5-018$ & 86.08 & 4 & 98.7 & 153.9 & 66.8 & 15 & 50 & 0.092 \\
\hline $04-5-113$ & 87.03 & 5 & 78.6 & 13.5 & 36.1 & 15 & 50 & 0.178 \\
\hline $04-6-006$ & 87.46 & 6 & 97.0 & 346.4 & -18.1 & 15 & 50 & 1.888 \\
\hline 04-6-094 & 88.34 & 4 & 99.6 & 344.1 & -4.8 & 15 & 50 & 1.375 \\
\hline $05-1-034$ & 89.34 & 4 & 99.5 & 234.2 & -58.7 & 15 & 50 & 0.993 \\
\hline $05-1-116$ & 90.16 & 4 & 99.5 & 268.1 & -80.6 & 15 & 50 & 0.735 \\
\hline $05-2-010$ & 90.60 & 4 & 92.2 & 17.0 & 49.4 & 15 & 50 & 0.313 \\
\hline $05-2-111$ & 91.61 & 4 & 98.3 & 344.1 & -29.7 & 15 & 50 & 0.558 \\
\hline $05-3-004$ & 92.04 & 4 & 79.1 & 77.1 & -9.8 & 15 & 50 & 0.605 \\
\hline $05-3-039$ & 92.39 & 4 & 99.7 & 356.9 & -52.5 & 15 & 50 & 0.863 \\
\hline $06-1-115$ & 99.75 & 4 & 99.9 & 171.0 & 38.6 & 15 & 50 & 1.803 \\
\hline $06-1-133$ & 99.93 & 5 & 99.9 & 327.3 & 45.2 & 10 & 50 & 2.323 \\
\hline $06-2-131$ & 101.41 & 5 & 100.0 & 204.3 & 51.4 & 10 & 50 & 3.440 \\
\hline $06-3-018$ & 101.78 & 5 & 100.0 & 253.6 & 54.2 & 10 & 50 & 2.525 \\
\hline $06-3-136$ & 102.96 & 5 & 99.9 & 77.0 & -44.0 & 10 & 50 & 1.627 \\
\hline $06-4-006$ & 103.16 & 5 & 99.5 & 88.3 & -38.9 & 10 & 50 & 1.118 \\
\hline $07-1-143$ & 109.43 & 5 & 100.0 & 310.6 & -52.4 & 10 & 50 & 1.958 \\
\hline $07-2-030$ & 109.80 & 5 & 100.0 & 109.9 & -49.8 & 10 & 50 & 3.142 \\
\hline $07-3-010$ & 111.10 & 5 & 99.9 & 324.2 & -55.6 & 10 & 50 & 2.007 \\
\hline $07-4-120$ & 113.70 & 5 & 99.9 & 298.1 & -53.7 & 10 & 50 & 3.103 \\
\hline $07-5-010$ & 114.10 & 5 & 99.7 & 346.4 & -52.2 & 10 & 50 & 1.443 \\
\hline $07-6-086$ & 116.36 & 5 & 99.9 & 212.7 & -50.0 & 10 & 50 & 3.460 \\
\hline $08-2-141$ & 120.21 & 5 & 97.8 & 191.7 & -53.4 & 10 & 50 & 2.092 \\
\hline $08-3-065$ & 120.95 & 5 & 100.0 & 250.6 & -48.6 & 10 & 50 & 1.988 \\
\hline $08-4-026$ & 122.06 & 5 & 98.8 & 30.3 & -47.9 & 10 & 50 & 0.905 \\
\hline 08-4-119 & 122.99 & 4 & 99.7 & 9.1 & 43.4 & 15 & 50 & 3.777 \\
\hline $08-5-015$ & 123.45 & 5 & 99.9 & 85.0 & 56.8 & 10 & 50 & 3.768 \\
\hline $08-5-067$ & 123.97 & 5 & 99.9 & 188.3 & 53.3 & 10 & 50 & 4.053 \\
\hline $08-5-126$ & 124.56 & 4 & 99.5 & 177.1 & 47.6 & 15 & 50 & 3.122 \\
\hline $09-1-008$ & 127.43 & 5 & 99.9 & 10.0 & -51.8 & 10 & 50 & 4.600 \\
\hline $09-1-075$ & 128.10 & 5 & 100.0 & 94.6 & -57.0 & 10 & 50 & 3.360 \\
\hline $09-2-047$ & 129.32 & 5 & 99.9 & 131.4 & -57.8 & 10 & 50 & 3.687 \\
\hline $09-3-020$ & 130.55 & 5 & 98.9 & 310.6 & -40.8 & 10 & 50 & 1.810 \\
\hline 09-4-118 & 133.03 & 5 & 100.0 & 44.8 & -52.6 & 10 & 50 & 3.413 \\
\hline $09-5-120$ & 134.55 & 5 & 99.8 & 153.7 & -49.1 & 10 & 50 & 4.613 \\
\hline $09-6-058$ & 135.43 & 5 & 99.5 & 326.8 & -51.7 & 10 & 50 & 2.013 \\
\hline $10-1-108$ & 137.48 & 5 & 99.6 & 52.6 & -46.2 & 10 & 50 & 2.733 \\
\hline $10-2-073$ & 138.63 & 5 & 99.8 & 318.7 & -46.1 & 10 & 50 & 3.482 \\
\hline $10-3-043$ & 139.83 & 5 & 99.9 & 324.0 & -49.2 & 10 & 50 & 4.603 \\
\hline $10-4-044$ & 141.34 & 5 & 100.0 & 146.4 & -52.1 & 10 & 50 & 4.380 \\
\hline $10-5-050$ & 142.90 & 5 & 99.9 & 340.0 & -56.2 & 10 & 50 & 2.390 \\
\hline
\end{tabular}


Table 3 (continued)

\begin{tabular}{|c|c|c|c|c|c|c|c|c|}
\hline Core-section level (cm) & Depth (mbsf) & $N$ & $\operatorname{Var}(\%)$ & $\operatorname{Dec}\left({ }^{\circ}\right)$ & $\operatorname{Inc}\left({ }^{\circ}\right)$ & $\mathrm{AF} 1(\mathrm{mT})$ & $\mathrm{AF} 2(\mathrm{mT})$ & Intensity $(\mathrm{mA} / \mathrm{m})$ \\
\hline $10-6-112$ & 145.02 & 5 & 99.9 & 315.9 & -29.0 & 10 & 50 & 5.095 \\
\hline 11-1-109 & 146.79 & 5 & 99.9 & 335.1 & -43.7 & 10 & 50 & 4.8567 \\
\hline $11-2-058$ & 147.78 & 4 & 99.9 & 317.6 & -53.6 & 15 & 50 & 3.180 \\
\hline $11-2-110$ & 148.30 & 5 & 99.9 & 9.9 & 49.7 & 10 & 50 & 7.233 \\
\hline $11-3-077$ & 149.47 & 5 & 99.8 & 219.4 & 56.6 & 10 & 50 & 3.787 \\
\hline $11-4-037$ & 150.57 & 5 & 98.5 & 343.7 & 30.9 & 10 & 50 & 1.973 \\
\hline $11-4-058$ & 150.78 & 4 & 91.7 & 196.5 & -50.8 & 15 & 50 & 2.585 \\
\hline $11-4-107$ & 151.27 & 5 & 99.8 & 65.4 & -29.7 & 10 & 50 & 4.987 \\
\hline $12-1-096$ & 155.96 & 5 & 99.7 & 150.0 & -37.3 & 10 & 50 & 2.773 \\
\hline $12-2-005$ & 156.55 & 5 & 99.1 & 164.5 & -58.3 & 10 & 50 & 3.060 \\
\hline $12-2-028$ & 156.78 & 4 & 68.2 & 40.3 & -40.9 & 15 & 50 & 0.668 \\
\hline $12-3-094$ & 158.94 & 5 & 99.8 & 81.2 & 43.2 & 10 & 50 & 2.235 \\
\hline $12-4-091$ & 160.41 & 5 & 99.9 & 106.4 & 40.5 & 10 & 50 & 3.127 \\
\hline $12-5-074$ & 161.74 & 6 & 95.6 & 74.8 & -39.0 & 10 & 50 & 0.352 \\
\hline $12-6-061$ & 163.11 & 4 & 96.3 & 184.2 & 48.1 & 15 & 50 & 1.483 \\
\hline $13-3-067$ & 168.27 & 4 & 99.5 & 172.2 & 34.1 & 20 & 50 & 2.498 \\
\hline $13-4-042$ & 169.52 & 4 & 97.2 & 30.3 & 32.6 & 15 & 50 & 0.657 \\
\hline $13-5-118$ & 171.78 & 4 & 99.0 & 8.8 & -28.1 & 15 & 50 & 0.993 \\
\hline $13-6-086$ & 172.96 & 4 & 100.0 & 116.9 & 67.3 & 15 & 50 & 1.110 \\
\hline $14-1-138$ & 174.98 & 4 & 98.5 & 348.9 & 41.6 & 15 & 50 & 1.268 \\
\hline $14-2-109$ & 176.19 & 4 & 95.6 & 16.6 & 49.3 & 15 & 50 & 0.822 \\
\hline
\end{tabular}

Table 4

Polarity magnetozones and correlative chrons for Site 384. Depth in mbsf=meters below sea-floor at Site 384; delta is uncertainty in depth of magnetozone boundary based on sampling interval; $\mathrm{N}=$ normal; $\mathrm{R}=$ reverse. Ages of magnetochrons from Berggren et al. $(1985)^{1}$, Cande and Kent $(1992)^{2}$, and Cande and Kent $(1995)^{3}$. $\mathrm{O}=$ onset; $\mathrm{T}=$ termination

\begin{tabular}{|c|c|c|c|c|c|c|}
\hline Depth (mbsf) & delta (m) & Sense & Magnetochron & $\operatorname{Age}^{1}(\mathrm{Ma})$ & $\operatorname{Age}^{2}(\mathrm{Ma})$ & $\operatorname{Age}^{3}(\mathrm{Ma})$ \\
\hline 102.37 & 0.59 & $\mathrm{R}-\mathrm{N}$ & $\mathrm{C} 25 \mathrm{n}(\mathrm{O})$ & 59.24 & 56.51 & 56.391 \\
\hline 122.53 & 0.47 & $\mathrm{~N}-\mathrm{R}$ & $\mathrm{C} 26 \mathrm{n}(\mathrm{T})$ & 60.21 & 57.80 & 57.554 \\
\hline 126.00 & 1.43 & $\mathrm{R}-\mathrm{N}$ & $\mathrm{C} 26 \mathrm{n}(\mathrm{O})$ & 60.75 & 58.20 & 57.911 \\
\hline 148.04 & 0.26 & $\mathrm{~N}-\mathrm{R}$ & $\mathrm{C} 27 \mathrm{n}(\mathrm{T})$ & 63.03 & 61.56 & 60.930 \\
\hline 150.68 & 0.10 & $\mathrm{R}-\mathrm{N}$ & $\mathrm{C} 27 \mathrm{n}(\mathrm{O})$ & 63.54 & 61.95 & 61.276 \\
\hline 156.80 & 0.10 & $\mathrm{~N}-\mathrm{R}$ & $\mathrm{C} 28 \mathrm{n}(\mathrm{T})$ & 64.29 & 63.30 & 62.499 \\
\hline $161.25^{\mathrm{a}}$ & 0.15 & $\mathrm{R}-\mathrm{N}$ & $\mathrm{C} 28 \mathrm{n}(\mathrm{O})$ & 65.12 & 64.54 & 63.634 \\
\hline $162.58^{\mathrm{a}}$ & 0.15 & $\mathrm{~N}-\mathrm{R}$ & $\mathrm{C} 29 \mathrm{n}(\mathrm{T})$ & 65.50 & 64.91 & 63.976 \\
\hline $168.10^{\mathrm{a}}$ & 0.10 & $\mathrm{R}-\mathrm{N}$ & $\mathrm{C} 29 \mathrm{n}(\mathrm{O})$ & 66.17 & 65.73 & 64.745 \\
\hline $169.05^{\mathrm{a}}$ & 0.10 & $\mathrm{~N}-\mathrm{R}$ & C30n(T) & 66.74 & 66.60 & 65.578 \\
\hline $170.28^{\mathrm{a}}$ & 0.10 & $\mathrm{R}-\mathrm{N}$ & $\mathrm{C} 30 \mathrm{n}(\mathrm{O})$ & 68.42 & 68.63 & 67.610 \\
\hline $171.68^{\mathrm{a}}$ & 0.10 & $\mathrm{~N}-\mathrm{R}$ & $\mathrm{C} 3 \ln (\mathrm{Y})$ & 68.52 & 68.75 & 67.735 \\
\hline
\end{tabular}

${ }^{\text {a }}$ Magnetostratigraphy from Larson and Opdyke (1979).

graphy. However, the $\sim 2 \%$ increase in benthic foraminifera $\delta^{13} \mathrm{C}$ starting in early Chron C26r offers a potential of correlation to within $\sim \pm 0.5$ my between $61 \mathrm{Ma}$ and $57 \mathrm{Ma}$. The start of this rise is also associated with an increase in the $\delta^{13} \mathrm{C}$ gradient between benthic foraminifera and fine fraction carbonate. Benthic foraminifera carbon isotope ratios from different ocean basins differed by less than $0.5 \%$ o throughout the late Paleocene (Corfield and Norris, 1996). Peak $\delta^{13} \mathrm{C}$ values occur within a narrow stratigraphic interval in diverse sites at about $57 \mathrm{Ma}$.

The oxygen isotope record at DSDP Site 384 is also broadly similar to that at other deep sea 


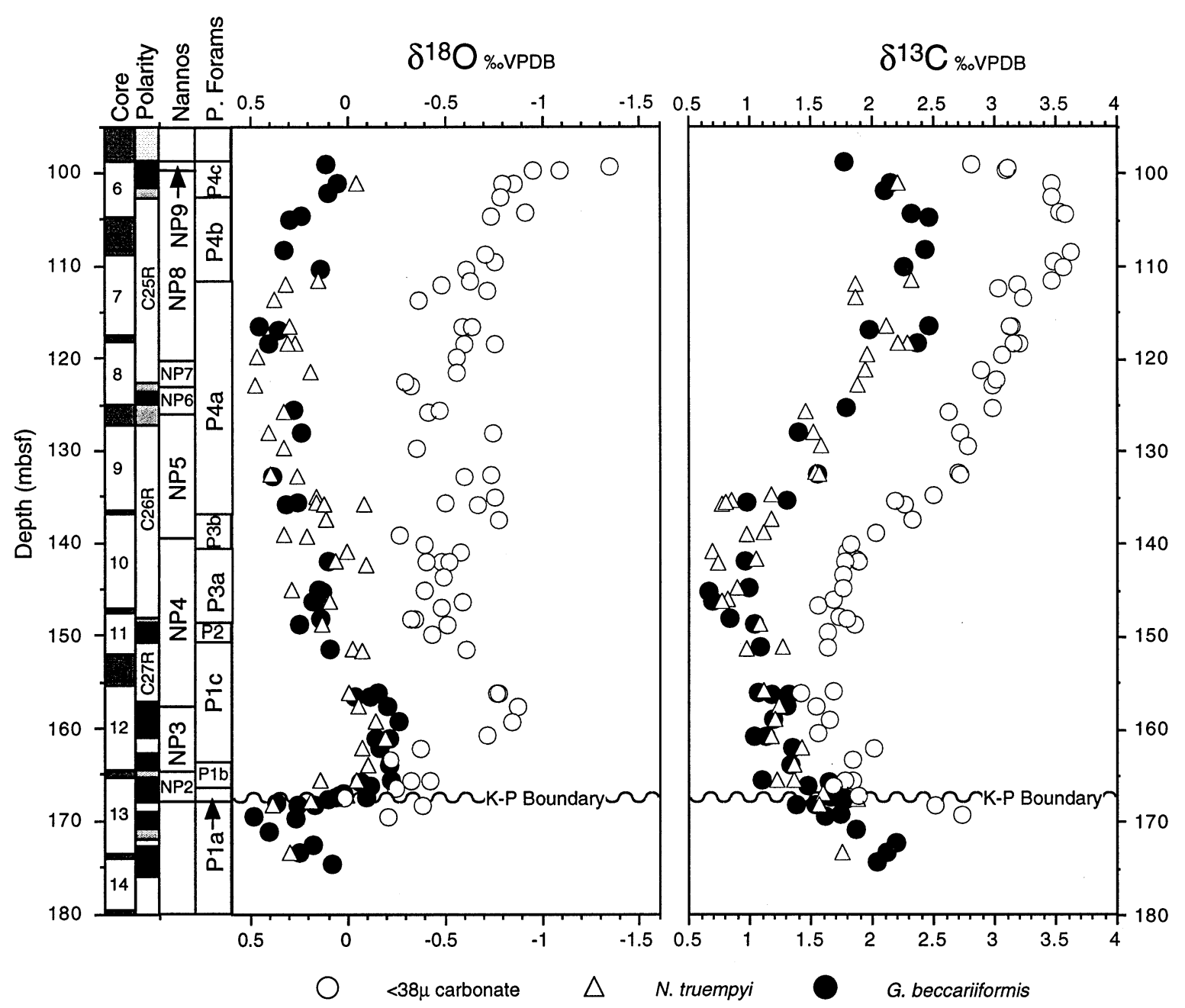

Fig. 7. Stable isotope stratigraphy (carbon and oxygen) of the Paleocene and upper Cretaceous interval (99-180 mbsf) at Site 384 . Isotopic values for fine fraction carbonate and benthic foraminifera plotted against a depth scale and correlated with magnetostratigraphy.

Paleocene sites. Records at DSDP Site 577 (Pacific), Sites 527 and 528 (South Atlantic), and ODP Site 690 (Southern Ocean) all show an interval of relatively negative $\delta^{18} \mathrm{O}$ at the $\mathrm{K} / \mathrm{P}$ boundary followed by a long-term increase in $\delta^{18} \mathrm{O}$ up to the lower Thanetian $(\sim 57.5-58 \mathrm{Ma})$ and then a return to more negative ratios in the uppermost Paleocene. The $\delta^{18} \mathrm{O}$ trend at DSDP Site 384 differs from this pattern in that upper Paleocene $\delta^{18} \mathrm{O}$ is more negative than is typical at other sites. Corfield and Norris (1996) interpreted this relatively negative $\delta^{18} \mathrm{O}$ at DSDP Site 384 as due to the presence of slightly warmer and saltier water in the deep North Atlantic compared to the rest of the deep ocean.

The relatively negative $\delta^{18} \mathrm{O}(<0.0 \%)$ is characteristic of the Danian at DSDP Site 384 and is largely confined to the interval between the K/P boundary and the top of Magnetozone C28n (Fig. 7). Hence, this interval of low $\delta^{18} \mathrm{O}$ values may be useful for identifying the Danian in other North Atlantic sites. 


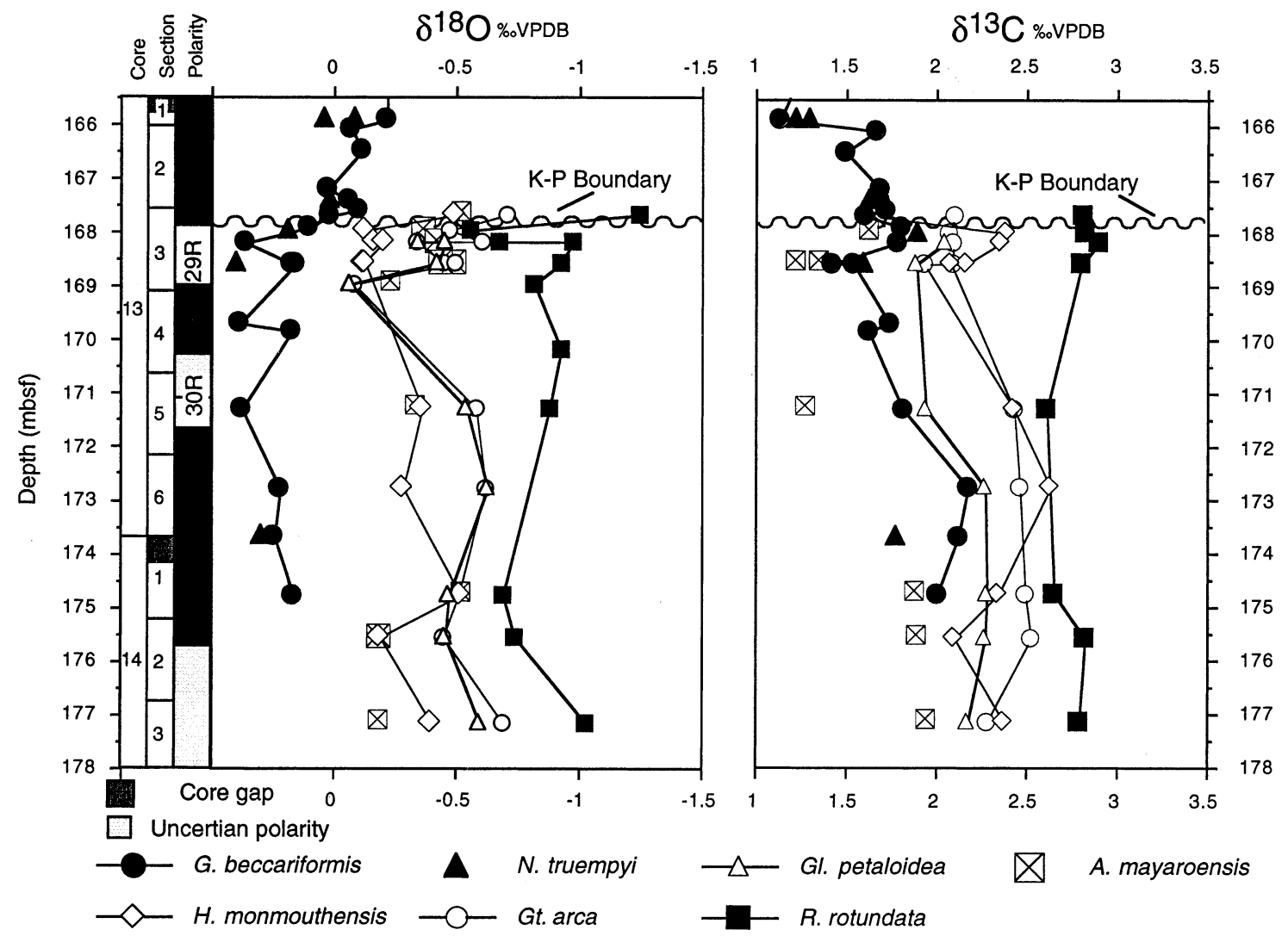

Fig. 8. Stable isotope (carbon and oxygen) stratigraphy across the K/P boundary at Site 384 (from 165.5 to $178 \mathrm{mbsf}$ ) integrated with magnetostratigraphy.

\section{Magnetobiochronology}

\subsection{Temporal interpretation}

Whereas shipboard scientists recognized that the upper Paleocene/lower Eocene contact is unconformable (Tucholke et al., 1979) in Hole 384, most believed that lithologic units IB and IC (98.6 to $\sim 192 \mathrm{mbsf}$ ) represented a continuous upper Paleocene to upper Maastrichtian succession, with the $\mathrm{K} / \mathrm{P}$ boundary recovered at 167.93 mbsf, moderately bioturbated and/or disturbed by drilling. However, both McNulty (1979) and Larson and Opdyke (1979) suggested that the contact is unconformable. In addition, Okada and Thierstein (1979) indicated that the upper part of Zone NP9 is present at the top of Core 6. We offer a different interpretation of the bounding limits of the Paleocene section (Figs. 10 and 11).

\subsubsection{The Maastrichtian/Danian contact (167.93 $m b s f)$}

Continuity across the $\mathrm{K} / \mathrm{P}$ boundary was based on biostratigraphic evidence constituted by both the occurrence of the $\mathrm{P} \alpha$ Zone (Parvularugoglobigerina eugubina Zone) between 167.53 and $167.13 \mathrm{mbsf}$ (LO of Parasubbotina pseudobulloides between 13-2, $143 \mathrm{~cm}$ and 13-2, $103 \mathrm{~cm}$; Boersma et al., 1979; see also Tucholke et al., 1979, p. 123) and that of Zone NP2 immediately above the $\mathrm{K} / \mathrm{P}$ contact. The occurrence of $C$. tenuis at such levels was seen as a reflection of excellent preservation rather than indication of a hiatus (Thierstein and Okada, 1979). 


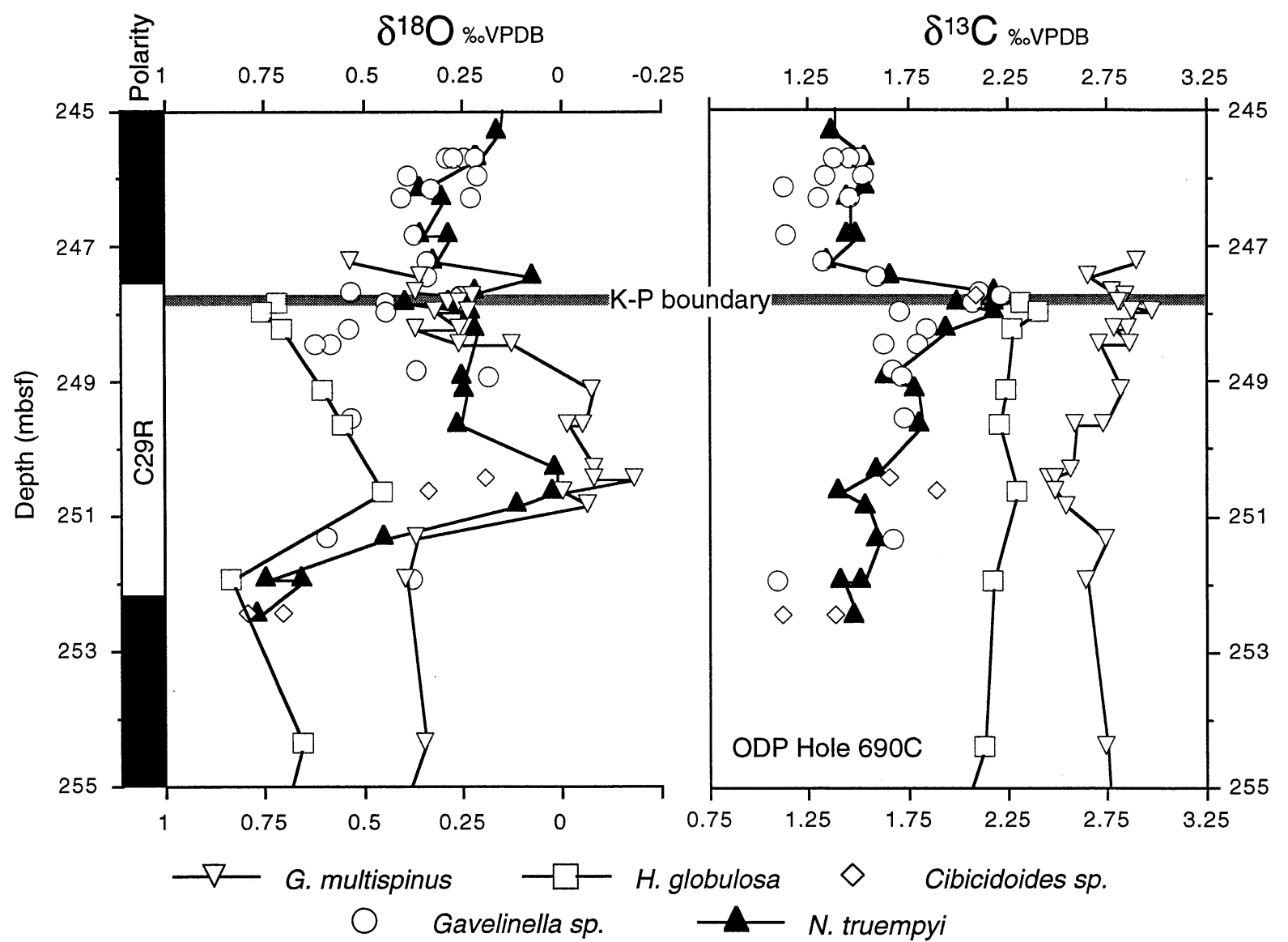

Fig. 9. Stable isotope (carbon and oxygen) stratigraphy across the K/P boundary at ODP Site 690C (between 245 and $255 \mathrm{mbsf}$ ). Isotopic data from Stott and Kennett, 1990. Magnetostratigraphy from Hamilton, 1990.

We have not found $P$. eugubina in the numerous samples we have examined in the vicinity of the $\mathrm{K} / \mathrm{P}$ contact (Fig. 3). Paleocene planktonic foraminifera of both Cretaceous and Danian ages are mixed together over an interval about $30 \mathrm{~cm}$ thick. The Paleocene taxa are also atypically large with many specimens present in the $>125 \mu \mathrm{m}$ fraction unlike the extremely dwarfed assemblages typical of the lowermost Danian at DSDP Sites 465 and 577, ODP Site 1049 and other locations such as Gubbio. Boersma et al. (1979) reported the presence of $P$. eugubina over an interval $>0.5 \mathrm{~m}$ thick above the K/P boundary at DSDP Site 384 . We have reanalyzed the sample set of Boersma et al. (1979) and were unable to identify $P$. eugubina, in these samples or in a suite of samples taken from the core for our study. There are extremely small specimens of Globanomalina archaeoimitata (Berggren and Norris, 1997) in the oldest Danian chalk present at DSDP Site 384, and it may be that these were identified as $P$. eugubina in the earlier study. Hence our work shows that the oldest Danian sediments at Site 384 belong to Zone P1a.

As determined by Thierstein and Okada (1979) the oldest Paleocene sediments also belong to Zone NP2, but, unlike those authors, we take this as a measure of the stratigraphic gap at the K/P contact, not as an indication of stratigraphic continuity. Thierstein and Okada (1979) proposed that Zone NP1 is an artificial zone found only in sections with poor preservation where assemblages 


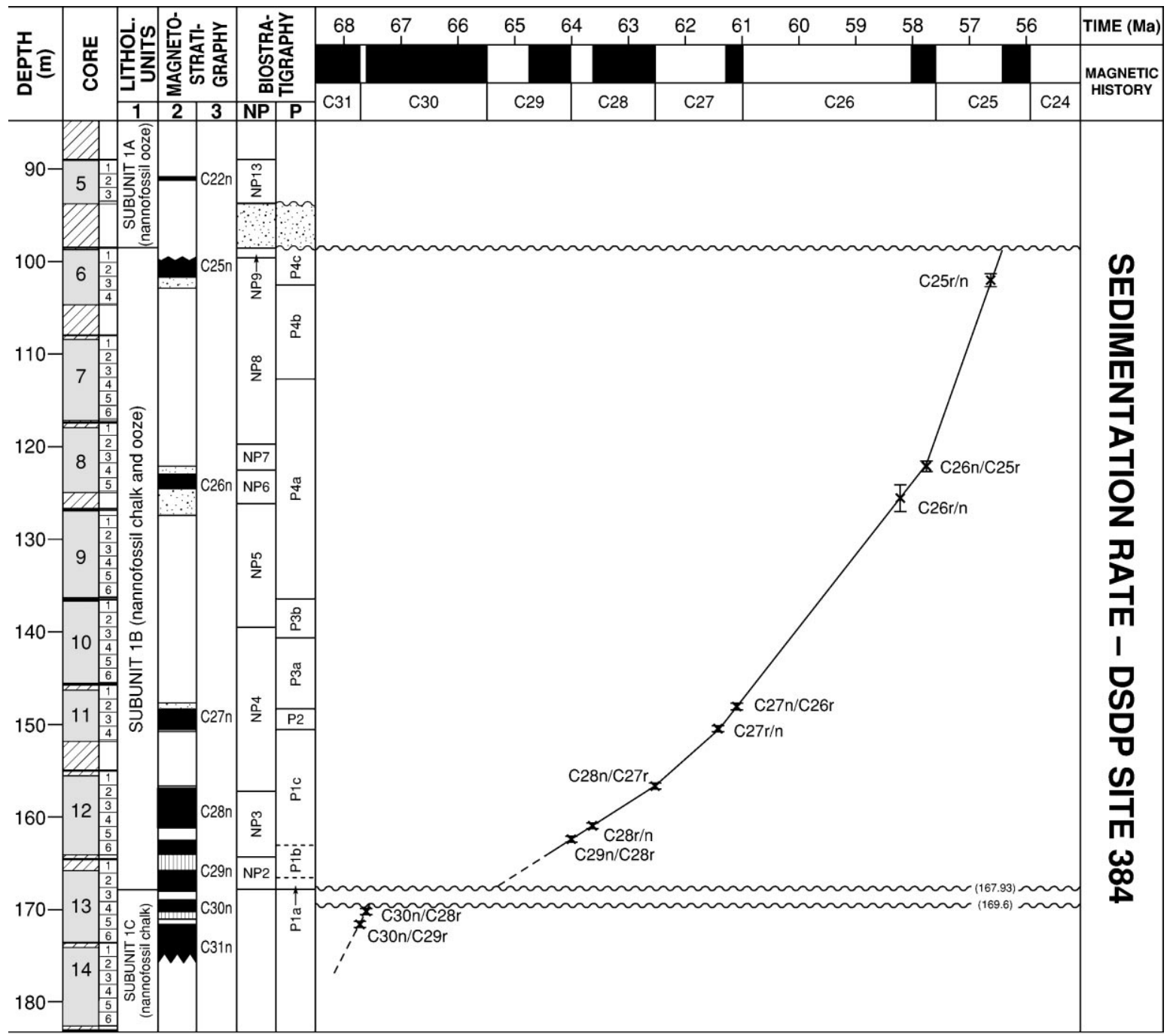

Fig. 10. Sedimentation rate estimate(s) for the uppermost Cretaceous and Paleocene section recovered from DSDP Site 384.

are strongly impoverished by dissolution which obliterate species of fragile construction such as $C$. tenuis and $C$. primus. In addition to the fact that the sequential occurrences of these two taxa have now been recognized in many $\mathrm{K} / \mathrm{P}$ sections, Thierstein himself has brought evidence that his interpretation was untenable. In a study of the effect of dissolution on upper Cretaceous and lower Paleocene calcareous nannofossil oozes (among which were samples from Site 384) he (Thierstein, 1980) concluded that the relative abundances of only a few taxa are changed by dissolution, $C$. primus being the most sensitive taxon, and $C$. tenuis being little affected. Finally, although we cannot use this as firm evidence (see above), the normal polarity interval between 167.93 and 166 mbsf may represent the early part of Chron C29n (not the earliest part of the chron). Thus magnetostratigraphic evidence converges with paleontologic evidence to demonstrate that the lowermost Paleocene is not represented at Site 384 (Fig. 10).

The reversed polarity interval between $\sim 168.10$ and $\sim 169.05 \mathrm{mbsf}$ has been identified as Chron 


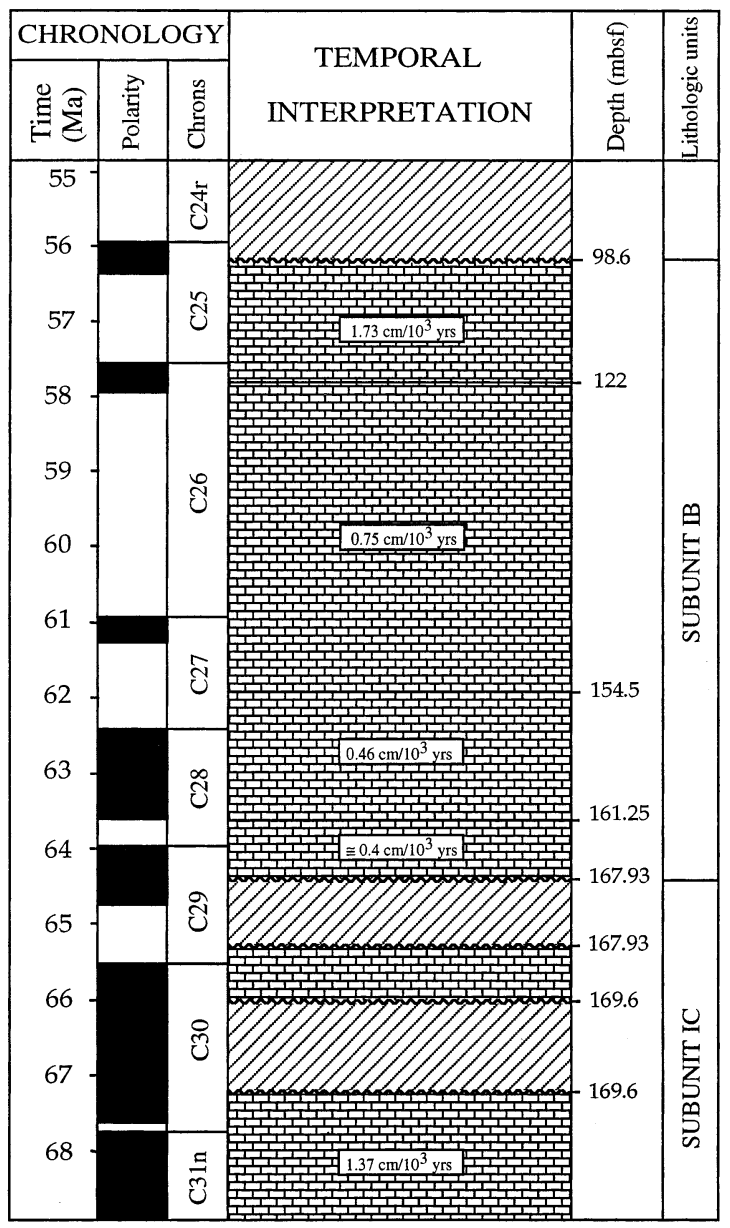

Calcareous nannoplankton claystone 77 Hiatus

Fig. 11. Temporal interpretation of the uppermost Cretaceous and Paleocene section recovered from DSDP Site 384. Unconformities/hiatuses shown by hatched pattern.

C29r (the upper part of the reversed magnetozone, between 167.93 and $168.10 \mathrm{mbsf}$, is likely to be remagnetized, see discussion above). This is well supported by oxygen isotopic data, with a distinct $\delta^{18} \mathrm{O}$ peak identified in other deep sea section in sediments representing earliest Chron C29r also present in Hole 384 (see above). The question is whether this $\sim 1 \mathrm{~m}$ interval represents all of the late Cretaceous part of the chron, or only its earliest part. McNulty (1979) determined that the uppermost Maastrichtian is not represented in the section based upon the co-occurrence of Globotruncanita gansseri and Abathomphalus mayaroensis. However, Robaszynski et al. (1984) noted that these two species co-occur throughout the upper Maastrichtian and thus do not represent a secure means of identifying a missing/absent uppermost Maastrichtian interval.

Carbon isotope stratigraphy supports McNulty's conclusion. Corfield and Norris (1996) observed that an increase in $\delta^{13} \mathrm{C}$ values immediately below the $\mathrm{K} / \mathrm{P}$ boundary was recorded at DSDP Site 577, ODP Site 738 and at Legs 14 and 113 sites (including Site 690), but not at DSDP Site 384. These authors explained this discrepancy as reflecting a latest Cretaceous transient reorganisation of deep water circulation. We propose that, instead, it reflects a latest Maastrichtian hiatus at Site 384. Corfield and Norris (1996) assigned an age of $\sim 65.2 \mathrm{Ma}$ to this $\delta^{13} \mathrm{C}$ enrichment. The similar magnitude and direction of isotopic shifts in DSDP Site 384 and ODP Site 690 suggest that both sections have recorded the same late Cretaceous warming and $\delta^{13} \mathrm{C}$ events. Accordingly, if the Maastrichtian portion of Chron $\mathrm{C} 29 \mathrm{r}$ is complete at ODP Site 690, then at least the lower $1 / 3$ to $1 / 2$ of Chron C29r ( $\sim 200 \mathrm{ky})$ is present at DSDP Site 384. This implies a Maastrichtian hiatus $>0.2$ my (Figs. 10 and 11).

We cannot determine precisely the age of the two bounding surfaces of the $\mathrm{K} / \mathrm{P}$ unconformity in Hole 384. The lower one has an age between 65.2 and 65.57 Ma (age of the Chron C29r/C30n reversal; Cande and Kent, 1995). The upper surface has an age slightly younger than $64.5 \mathrm{Ma}$, the FAD of C. tenuis (BKSA95). As indicated above we believe that early morphotypes of $C$. tenuis occur immediately above $167.93 \mathrm{mbsf}$. It should normally be possible to determine the age of the upper surface at $167.93 \mathrm{mbsf}$ through extrapolation of the sedimentation rates between magnetic reversals above. The interval representing Chron $\mathrm{C} 28 \mathrm{r}-\mathrm{C} 28 \mathrm{n}$ was deposited at a rate of $0.46 \mathrm{~cm} / 10^{3} \mathrm{yr}$. If we apply this rate to the interval representing the late part of Chron C29n, we determine an age of 65.37 Ma (i.e. late Cretaceous) for the upper surface at $167.93 \mathrm{mbsf}$, which is 
obviously impossible. This implies that the interval representing Chron $\mathrm{C} 29 \mathrm{n}$ was deposited at higher rates than $0.4 \mathrm{~cm} / 10^{3} \mathrm{yr}$, which is in agreement with partial sediment mixing above the $\mathrm{K} / \mathrm{P}$ boundary (Thierstein and Okada, 1979; Boersma et al., 1979; McNulty, 1979). Our study confirms the observation by McNulty (1979, p. 488) that the basal part of the Danian sequence recovered yields "many burrows filled with considerable Cretaceous clay. As a result, samples from the Danian yield a mixture of Cretaceous and Tertiary forms". We recognize however that if the sediment in Core 13 should be shifted to the top of section 1 (which is most likely) at $164.60 \mathrm{mbsf}$ (see above), the age of the upper surface of the unconformity at 166.68 mbsf would be $64.07 \mathrm{Ma}$ based on a sedimentation rate of $0.46 \mathrm{~cm} / 10^{3} \mathrm{yr}$ for the upper part of Magnetozone C29n. We estimate the hiatus at the $\mathrm{K} / \mathrm{P}$ in Hole 384 to be $\sim 0.9$ my.

We stress that the interpretation of the uppermost Maastrichtian stratigraphic interval at Site 384 is extremely difficult. Chron C30n is 2.03 my long but is only represented by $1.23 \mathrm{~m}$ of section (Table 3). If the whole chron was represented, this would imply a very low sedimentation rate of only $0.6 \mathrm{~m} / \mathrm{my}$. We propose, rather, the presence of a significant unconformity truncating Magnetozone $\mathrm{C} 30$ n (i.e. in addition to the $\mathrm{K} / \mathrm{P}$ unconformity). We cannot locate confidently an unconformity in the core. We arbitrarily locate it within Magnetozone C30n, recognizing that it could coincide with the Magnetozone C30n/C29r or $\mathrm{C} 30 \mathrm{r} / \mathrm{C} 30 \mathrm{n}$ boundary. The position (at $169.60 \mathrm{mbsf}$ ) and the duration ( $\sim 1 \mathrm{my}$ ) of the hiatus are arbitrarily estimated in the temporal interpretation of the section (Fig. 11).

\subsubsection{The Paleocene/Eocene contact}

There is a $>4.5 \mathrm{~m}$ recovery gap between Cores 5 and 6, at the contact between the Paleocene and lower Eocene. The oldest sediments recovered from Core 5 belong to Zone NP13 (Okada and Thierstein, 1979; MPA, personal observations), and to Zone P9 (Tucholke et al., 1979). They are predominantly of reversed polarity and should therefore correlate with Chron C22r. The youngest sediments in Core 6 belong to Zone NP9 (Okada and Thierstein, 1979; this work), Zone P4c (see above) and represent Chron C25n (see above). Okada and Thierstein (1979) recorded the LO of Cruciplacolithus delus in the uppermost part of Core 6 and, on this basis, reported on the presence of the upper part of Zone NP9 (Subzone CP8b of Okada and Bukry, 1980) between $\sim 102 \mathrm{~m}$ and $98.6 \mathrm{~m}$ (top of Core 6). It has now been shown that the LO of $C$. delus compared to that of Rhomboaster cuspis (the other marker of the base of Subzone CP8b) is inconsistent between sections and constitutes an unreliable criterion to determine a level in $\sim$ mid Zone NP9 (Bralower and Mutterlose, 1995; Aubry, submitted). The stratigraphic gap encompasses Chron C24r to early Chron C22r, and the hiatus is estimated to be $\sim 6$ my. Based on calculated sedimentation rates of $1.73 \mathrm{~cm} / 10^{3} \mathrm{yr}$ in the NP7-NP9 zonal interval, we estimate an age of $56.17 \mathrm{Ma}$ for the lower surface of the unconformity.

\subsubsection{Paleocene sedimentation rates}

We have established that all magnetochrons from Chron C29n (partim) to Chron C25n (partim), all calcareous nannofossil zones from NP2 to NP9 and all planktonic foraminiferal zones and subzones from $\mathrm{P} 1 \mathrm{a}$ to $\mathrm{P} 4 \mathrm{c}$ are present in the Paleocene of Site 384. Nevertheless, as Aubry (1993, 1995) has shown, a normal bio/magnetozonal succession is not a guarantee of sedimentary continuity. Using the magnetozone boundaries in the section and the age of the correlative magnetic reversals estimated by Cande and Kent (1995) we show that the Paleocene sedimentary succession at Site 384 is essentially complete/continuous over at least the $65 \mathrm{~m}$ interval between $164 \mathrm{~m}$ and $98.6 \mathrm{~m}$ with the following rate(s) of sedimentation (Fig. 11):

$0.40 \mathrm{~cm} / 10^{3} \mathrm{yr}$ between 164 and $154.50 \mathrm{mbsf}$ (Chron C29n/C28r to Chron C28n/C27r);

$0.46 \mathrm{~cm} / 10^{3} \mathrm{yr}$ between 154.50 and $151.25 \mathrm{mbsf}$ (Chron C28n/C27r to Chron C27r/n);

$0.75 \mathrm{~cm} / 10^{3} \mathrm{yr}$ between 151.25 and $122 \mathrm{mbsf}$ (Chron C27r/n to Chron C26n/C25r);

$1.73 \mathrm{~cm} / 10^{3} \mathrm{yr}$ between 122 and $98.6 \mathrm{mbsf}$ (Chron C26n/C25r to Chron C25n).

The sedimentation rates for the interval between 167.93 and $164 \mathrm{mbsf}$ are indeterminate.

The inflection at $154.5 \mathrm{~m}$ (Chron C27r; late 
Table 5

Quantitative data (numerical counts and percentages) of planktonic foraminiferal taxa in 16 samples from the uppermost Cretaceous (Maastrichtian) to upper Paleocene (upper Thanetian) at DSDP Site 384

\begin{tabular}{|c|c|c|c|c|c|c|c|}
\hline & $\begin{array}{l}\text { Sample } \\
\text { NT }\end{array}$ & $\begin{array}{l}\text { 13/4: } 62-64 \\
200\end{array}$ & $\begin{array}{l}\text { 13/3: } 10-12 \\
200\end{array}$ & $\begin{array}{l}\text { 13/2: } 49-51 \\
200\end{array}$ & $\begin{array}{l}\text { 13/1: } 136-138 \\
700\end{array}$ & $\begin{array}{l}12 / 3: 136-138 \\
700\end{array}$ & $\begin{array}{l}11 / 3: 136-138 \\
700\end{array}$ \\
\hline \multirow[t]{2}{*}{ Indeterminate } & NB & 5 & 5 & 4 & 16 & 12 & 11 \\
\hline & $\%$ & 2.5 & 2.5 & 2 & 2.3 & 1.7 & 1.6 \\
\hline \multirow[t]{2}{*}{ Globotruncanidae } & NB & 146 & 95 & & & & \\
\hline & $\%$ & 72 & 47.5 & & & & \\
\hline \multirow[t]{2}{*}{ Heterohelicidae } & NB & 49 & 70 & & 128 & 34 & \\
\hline & $\%$ & 24.8 & 35 & & 18.5 & 5.3 & \\
\hline \multirow[t]{2}{*}{ Hedbergella } & NB & & 30 & & & & \\
\hline & $\%$ & & 15 & & & & \\
\hline \multirow[t]{2}{*}{ E. eobulloides } & NB & & & 28 & 116 & & \\
\hline & $\%$ & & & 14 & 17.8 & & \\
\hline \multirow[t]{2}{*}{ S. trivialis } & NB & & & 6 & & & \\
\hline & $\%$ & & & 3 & & & \\
\hline \multirow[t]{2}{*}{ Pr. pseudoinconstans } & NB & & & 153 & 355 & & \\
\hline & $\%$ & & & 76.5 & 51 & & \\
\hline \multirow[t]{2}{*}{ Pr. taurica } & NB & & & 2 & 8 & 8 & \\
\hline & $\%$ & & & 1 & 1.2 & 1.2 & \\
\hline \multirow[t]{2}{*}{ Gl. planocompressa } & NB & & & 7 & 32 & & \\
\hline & $\%$ & & & 3.5 & 4.6 & & \\
\hline \multirow[t]{2}{*}{ E. edita } & NB & & & & 6 & 13 & \\
\hline & $\%$ & & & & 0.9 & 1.9 & \\
\hline \multirow[t]{2}{*}{ G. daubjergensis } & NB & & & & 30 & 26 & \\
\hline & $\%$ & & & & 4.3 & 3.7 & \\
\hline \multirow[t]{2}{*}{ S. triloculinoides } & NB & & & & 9 & 218 & 167 \\
\hline & $\%$ & & & & 1.3 & 31.1 & 23.9 \\
\hline \multirow[t]{2}{*}{ P. varianta } & NB & & & & & 72 & 178 \\
\hline & $\%$ & & & & & 10.3 & 25.4 \\
\hline \multirow[t]{2}{*}{ Pr. inconstans } & NB & & & & & 258 & 48 \\
\hline & $\%$ & & & & & 36.1 & 6.9 \\
\hline \multirow[t]{2}{*}{ Gl. compressa } & NB & & & & & 50 & 50 \\
\hline & $\%$ & & & & & 7.2 & 7.2 \\
\hline \multirow[t]{2}{*}{ Gl. imitata } & NB & & & & & 9 & \\
\hline & $\%$ & & & & & 1.3 & \\
\hline \multirow[t]{2}{*}{ Pr. uncinata } & NB & & & & & & 128 \\
\hline & $\%$ & & & & & & 18.3 \\
\hline \multirow[t]{2}{*}{ M. praeangulata } & NB & & & & & & 48 \\
\hline & $\%$ & & & & & & 6.9 \\
\hline \multirow[t]{2}{*}{ Pr. spiralis } & NB & & & & & & 48 \\
\hline & $\%$ & & & & & & 6.9 \\
\hline \multirow[t]{2}{*}{ Gl. ehrenbergi } & NB & & & & & & 4 \\
\hline & $\%$ & & & & & & 0.6 \\
\hline
\end{tabular}

early Paleocene; Figs. 10 and 11) reflects the increased productivity resulting from recovery of the calcareous plankton following the $\mathrm{K} / \mathrm{P}$ boundary extinction/catastrophe and the influx of biosiliceous organisms (radiolaria, in particular). The inflection at $122 \mathrm{~m}$ [Chron $\mathrm{C} 26 \mathrm{n}_{(\mathrm{y})}$; early late Paleocene] reflects increased productivity resulting from the significant increase in biosiliceous components (radiolarians, diatoms) in the coarse fraction $(\sim />90 \%$ in some levels) in Cores $8-6$.

Our estimates of the ages of the Paleocene planktonic microfossil datums and isotopic $\delta^{13} \mathrm{C}$ events are based on the calculated sedimentation rates given above. 
Table 5 (continued)

\begin{tabular}{|c|c|c|c|c|c|c|}
\hline & $\begin{array}{l}\text { Sample } \\
\text { NT }\end{array}$ & $\begin{array}{l}10 / 5: 136-138 \\
600\end{array}$ & $\begin{array}{l}\text { 10/1: } 136-138 \\
140\end{array}$ & $\begin{array}{l}\text { 9/6: 136-138 } \\
610\end{array}$ & $\begin{array}{l}\text { 9/2: 136-138 } \\
560\end{array}$ & $\begin{array}{l}\text { 8/3: } 132-134 \\
375\end{array}$ \\
\hline \multirow[t]{2}{*}{ Indeterminate } & NB & 16 & 4 & 0 & 2 & 1 \\
\hline & $\%$ & 2.7 & 2.9 & 0 & 0.4 & 0.3 \\
\hline \multirow[t]{2}{*}{ Heterohelicidae } & NB & 2 & & 10 & & \\
\hline & $\%$ & 0.3 & & 1.6 & & \\
\hline \multirow[t]{2}{*}{ S. triloculinoides } & NB & 116 & 2 & 2 & 72 & 51 \\
\hline & $\%$ & 19.3 & 1.4 & 0.3 & 12.9 & 13.6 \\
\hline \multirow[t]{2}{*}{ P. varianta } & NB & 117 & 31 & 115 & & \\
\hline & $\%$ & 19.5 & 22.1 & 18.8 & & \\
\hline \multirow[t]{2}{*}{ Gl. compressa } & NB & 2 & & & & \\
\hline & $\%$ & 0.3 & & & & \\
\hline \multirow[t]{2}{*}{ Gl. imitata } & NB & 4 & & 2 & & 1 \\
\hline & $\%$ & 0.7 & & 0.4 & & 0.2 \\
\hline \multirow[t]{2}{*}{ Gl. ehrenbergi } & NB & 59 & & & & \\
\hline & $\%$ & 9.8 & & & & \\
\hline \multirow[t]{2}{*}{ P. pseudobulloides } & NB & 10 & & & 2 & \\
\hline & $\%$ & 1.7 & & & 0.4 & \\
\hline \multirow[t]{2}{*}{ S. triangularis } & NB & 37 & & 90 & 100 & 24 \\
\hline & $\%$ & 6.2 & & 14.8 & 17.9 & 6.4 \\
\hline \multirow[t]{2}{*}{ S. velascoensis } & NB & & & 70 & 86 & 18 \\
\hline & $\%$ & & & 11.5 & 15.4 & 4.8 \\
\hline \multirow[t]{2}{*}{ Ig. pusilla } & NB & 12 & & & & \\
\hline & $\%$ & 2 & & & & \\
\hline \multirow[t]{2}{*}{ Pr. quadrilocula } & NB & 71 & & & & \\
\hline & $\%$ & 11.8 & & & & \\
\hline \multirow[t]{2}{*}{ M. angulata } & NB & 112 & 61 & 18 & & \\
\hline & $\%$ & 18.7 & 43.5 & 3 & & \\
\hline \multirow[t]{2}{*}{ M. occlusa } & NB & 32 & 4 & 69 & 3 & 2 \\
\hline & $\%$ & 5.3 & 2.9 & 11.4 & 0.5 & 0.5 \\
\hline \multirow[t]{2}{*}{ Ig. albeari } & NB & 9 & 1 & & 12 & 38 \\
\hline & $\%$ & 1.5 & 0.7 & & 2.1 & 10.1 \\
\hline \multirow[t]{2}{*}{ Ig. tadjikistanensis } & NB & 1 & 10 & & 16 & 61 \\
\hline & $\%$ & 0.2 & 7.3 & & 2.9 & 16.3 \\
\hline \multirow[t]{2}{*}{ M. conicotruncata } & NB & & 6 & 4 & & \\
\hline & $\%$ & & 4.3 & 0.7 & & \\
\hline \multirow[t]{2}{*}{ M. velascoensis } & NB & & 12 & 70 & 135 & 29 \\
\hline & $\%$ & & 8.7 & 11.5 & 24.1 & 7.7 \\
\hline \multirow[t]{2}{*}{ M. apanthesma } & NB & & 9 & 111 & 13 & 1 \\
\hline & $\%$ & & 6.5 & 18.2 & 2.3 & 0.3 \\
\hline Ig. trichotrocha & NB & & & 3 & & \\
\hline & $\%$ & & & 0.5 & & \\
\hline P. variospira & NB & & & 5 & & \\
\hline & $\%$ & & & 0.8 & & \\
\hline Ac. strabocella & NB & & & 5 & & \\
\hline & $\%$ & & & 0.8 & & \\
\hline Gl. pseudomenardii & NB & & & 38 & 7 & 2 \\
\hline & $\%$ & & & 6.4 & 1.3 & 0.5 \\
\hline Ac. nitida & NB & & & & 83 & 111 \\
\hline & $\%$ & & & & 14.8 & 29.6 \\
\hline Ac. mckannai & NB & & & & & 2 \\
\hline & $\%$ & & & & & 0.5 \\
\hline Ac. subsphaerica & NB & & & & 2 & 35 \\
\hline & $\%$ & & & & 0.4 & 9.3 \\
\hline
\end{tabular}


Table 5 (continued)

\begin{tabular}{|c|c|c|c|c|c|c|}
\hline & $\begin{array}{l}\text { Sample } \\
\text { NT }\end{array}$ & $\begin{array}{l}8 / 1: 136-138 \\
550\end{array}$ & $\begin{array}{l}\text { 7/4: } 130-132 \\
600\end{array}$ & $\begin{array}{l}\text { 7/1: 90-92 } \\
600\end{array}$ & $\begin{array}{l}\text { 6/3: 92-94 } \\
500\end{array}$ & $\begin{array}{l}\text { 6/1: 89-91 } \\
600\end{array}$ \\
\hline \multirow[t]{2}{*}{ Indeterminate } & NB & 1 & 7 & 16 & 6 & 10 \\
\hline & $\%$ & 0.2 & 1.2 & 2.7 & 1.2 & 1.7 \\
\hline \multirow[t]{2}{*}{ S. triloculinoides } & NB & 53 & 56 & 45 & 128 & 34 \\
\hline & $\%$ & 9.6 & 9.3 & 7.5 & 18.5 & 5.3 \\
\hline \multirow[t]{2}{*}{ Gl. imitata } & NB & 1 & 4 & 2 & 4 & 23 \\
\hline & $\%$ & 0.2 & 0.7 & 0.3 & 0.7 & 3.8 \\
\hline \multirow[t]{2}{*}{ P. pseudobulloides } & NB & 3 & & & & \\
\hline & $\%$ & 0.5 & & & & \\
\hline \multirow[t]{2}{*}{ S. triangularis } & NB & 72 & 71 & 37 & 29 & 10 \\
\hline & $\%$ & 13.1 & 11.8 & 6.2 & 5.8 & 1.7 \\
\hline \multirow[t]{2}{*}{ S. velascoensis } & NB & 43 & 193 & 90 & 62 & 46 \\
\hline & $\%$ & 7.8 & 32.2 & 15 & 12.4 & 7.7 \\
\hline \multirow[t]{2}{*}{ M. occlusa } & NB & 3 & 20 & 31 & 10 & 25 \\
\hline & $\%$ & 0.5 & 3.3 & 5.2 & 2 & 4.2 \\
\hline \multirow[t]{2}{*}{ Ig. albeari } & NB & 15 & 18 & 1 & 3 & \\
\hline & $\%$ & 2.7 & 3 & 0.2 & 0.6 & \\
\hline \multirow[t]{2}{*}{ Ig. tadjikistanensis } & NB & 88 & 5 & 67 & 128 & 34 \\
\hline & $\%$ & 16 & 0.8 & 11.1 & 25.6 & 5.7 \\
\hline \multirow[t]{2}{*}{ M. velascoensis } & NB & 53 & 11 & 53 & 3 & 47 \\
\hline & $\%$ & 9.6 & 1.8 & 8.8 & 0.6 & 7.8 \\
\hline \multirow[t]{2}{*}{ M. apanthesma } & NB & 4 & 16 & 55 & 57 & 51 \\
\hline & $\%$ & 0.7 & 2.7 & 9.2 & 11.4 & 8.5 \\
\hline \multirow[t]{2}{*}{ Ac. strabocella } & NB & 1 & & & & \\
\hline & $\%$ & 0.2 & & & & \\
\hline \multirow[t]{2}{*}{ Gl. pseudomenardii } & NB & 5 & 27 & 15 & 3 & 15 \\
\hline & $\%$ & 0.9 & 4.5 & 2.5 & 0.6 & 2.5 \\
\hline \multirow[t]{2}{*}{ Ac. nitida } & NB & 137 & 54 & 157 & 136 & \\
\hline & $\%$ & 24.9 & 9 & 26.2 & 27.2 & \\
\hline \multirow[t]{2}{*}{ Ac. mckannai } & NB & 10 & 12 & 31 & 41 & 13 \\
\hline & $\%$ & 1.8 & 2 & 5.2 & 8.2 & 2.2 \\
\hline \multirow[t]{2}{*}{ Ac. subsphaerica } & NB & 47 & 106 & & & \\
\hline & $\%$ & 8.5 & 17.7 & & & \\
\hline \multirow[t]{2}{*}{ Gl. pseudoimitata } & NB & 14 & & & 2 & \\
\hline & $\%$ & 2.5 & & & 0.4 & \\
\hline \multirow[t]{2}{*}{ M. acuta } & NB & & & & 4 & 1 \\
\hline & $\%$ & & & & 0.8 & 0.2 \\
\hline \multirow[t]{2}{*}{ M. pasionensis } & NB & & & & 2 & 3 \\
\hline & $\%$ & & & & 0.4 & 0.5 \\
\hline \multirow[t]{2}{*}{ S. patagonica } & NB & & & & & 67 \\
\hline & $\%$ & & & & & 11.2 \\
\hline \multirow[t]{2}{*}{ M. aеqua } & NB & & & & 2 & 87 \\
\hline & $\%$ & & & & 0.4 & 14.5 \\
\hline Ac. coalingensis & NB & & & & 5 & 144 \\
\hline & $\%$ & & & & 1 & 24 \\
\hline Ac. soldadoensis & NB & & & & 2 & 23 \\
\hline & $\%$ & & & & 0.4 & 3.8 \\
\hline Gl. chapmani & NB & & & & & 1 \\
\hline & $\%$ & & & & & 0.2 \\
\hline
\end{tabular}


Table 6

Comparison of the magnetobiochronology of planktonic foraminiferal datum events identified in BKSA95 and this paper. Datums identified as new in this paper are in boldface type

\begin{tabular}{|c|c|c|c|c|}
\hline \multirow[t]{2}{*}{ Datum } & \multirow[t]{2}{*}{ FAD } & \multirow[t]{2}{*}{ LAD } & \multicolumn{2}{|l|}{ Age (Ma) } \\
\hline & & & BKSA, 1995 & This work \\
\hline M. acuta & & $\mathrm{X}$ & 54.7 & \\
\hline M. velascoensis & & $\mathrm{X}$ & 54.7 & \\
\hline Gl. australiformis & $\mathrm{X}$ & & 55.5 & \\
\hline M. subbotinae & $\mathrm{X}$ & & 55.9 & \\
\hline Gl. pseudomenardii & & $\mathrm{X}$ & 55.9 & \\
\hline Ac. nitida & & $\mathrm{X}$ & 56.3 & 56.3 \\
\hline Ac. mckannai & & $\mathrm{X}$ & 56.3 & 56.3 \\
\hline Ig. albeari & & $\mathrm{X}$ & & 56.3 \\
\hline Ac. soldadoensis & $\mathrm{X}$ & & 56.5 & 56.5 \\
\hline Ac. coalingensis & $\mathrm{X}$ & & 56.5 & 56.5 \\
\hline M. aequa & $\mathrm{X}$ & & 56.5 & 56.5 \\
\hline S. triloculinoides & & $\mathrm{X}$ & & 56.5 \\
\hline Ac. subsphaerica & & $\mathrm{LCO}$ & 57.1 & 57.1 \\
\hline M. conicotruncata & & $\mathrm{X}$ & & 58.8 \\
\hline P. varianta & & $\mathrm{X}$ & 59.2 & 58.8 \\
\hline Ac. mckannai & $\mathrm{X}$ & & 59.1 & \\
\hline M. angulata & & $\mathrm{X}$ & & 59.1 \\
\hline Ig. trichotrocha & & $\mathrm{X}$ & & 59.1 \\
\hline Ac. nitida & $\mathrm{X}$ & & 59.2 & 59.2 \\
\hline Ac. subsphaerica & $\mathrm{X}$ & & 59.2 & 59.2 \\
\hline P. variospira & & $\mathrm{X}$ & 59.2 & 59.2 \\
\hline S. velascoensis & $\mathrm{X}$ & & & 59.4 \\
\hline Gl. pseudomenardii & $\mathrm{X}$ & & 59.2 & 59.4 \\
\hline M. velascoensis & $\mathrm{X}$ & & 60.0 & 60.0 \\
\hline Ig. albeari & $\mathrm{X}$ & & 60.0 & 60.0 \\
\hline Ig. pusilla & & $\mathrm{X}$ & & 60.0 \\
\hline Ig. trichotrocha & $\mathrm{X}$ & & & 60.2 \\
\hline M. apanthesma & $\mathrm{X}$ & & & 60.2 \\
\hline Ig. tadjikistanensis & $\mathrm{X}$ & & & 60.5 \\
\hline Ac. strabocella & $\mathrm{X}$ & & 60.5 & 60.6 \\
\hline Ig. aff. albeari & $\mathrm{X}$ & & & 60.7 \\
\hline$P$. variospira & $\mathrm{X}$ & & & 60.9 \\
\hline M. conicotruncata & $\mathrm{X}$ & & 60.9 & 60.9 \\
\hline Pr. inconstans & & $\mathrm{X}$ & & 60.9 \\
\hline M. praeangulata & & $\mathrm{X}$ & & 60.9 \\
\hline Ig. pusilla & $\mathrm{X}$ & & 61.0 & 61.0 \\
\hline M. angulata & $\mathrm{X}$ & & 61.0 & 61.0 \\
\hline Pr. uncinata & & $\mathrm{X}$ & & 61.0 \\
\hline Pr. uncinata & $\mathrm{X}$ & & 61.2 & 61.2 \\
\hline M. praeangulata & $\mathrm{X}$ & & 61.2 & 61.2 \\
\hline G. daubjergensis & & $\mathrm{X}$ & & 61.2 \\
\hline Gl. imitata & $\mathrm{X}$ & & $(61.3)$ & \\
\hline Pr. taurica & & $\mathrm{X}$ & & 62.9 \\
\hline Pr. inconstans & $\mathrm{X}$ & & 63.0 & 63.0 \\
\hline Gl. compressa & $\mathrm{X}$ & & 63.0 & 63.0 \\
\hline P. varianta & $\mathrm{X}$ & & 63.0 & 63.0 \\
\hline S. triloculinoides & $\mathrm{X}$ & & 64.3 & 64.3 \\
\hline P. eugubina & & $\mathrm{X}$ & 64.7 & \\
\hline P. eugubina & $\mathrm{X}$ & & 65.0 & \\
\hline Globotruncana & & $\mathrm{X}$ & 65.0 & \\
\hline
\end{tabular}




\subsection{Planktonic foraminifera biochronology}

In BKSA95 the Paleocene interval (for practical purposes) was bracketed by the extinction of the Cretaceous planktonic foraminifera Globotruncana and Rugolobigerina datum events and the $\mathrm{HO}$ of Morozovella acuta/velascoensis. Over 30 datum events were recognized and calibrated to the GPTS. Many of these were based on the study of Site 384. In a recent unpublished quantitative study using more closely spaced samples (Table 5), Quillévéré (1996) has identified nearly 40 datum events (several of which are new to the IMBS) at Site 384. These are listed in Table 6. Comparison of the estimated ages of datum events common to the two independent studies (one qualitative the other quantitative) shows that most of the newly derived values are closely comparable, seldom deviating by more than 0.1 to $0.2 \mathrm{my}$. Major deviations from BKSA95 include the following.

(a) The questionable, significantly lower/older estimate - 60.7 Ma (vs. 60.0 Ma in BKSA95) for the FAD of Igorina albeari, a small, nonspinose, cancellate, biconvex, keeled form used to define the base of Subzone P3b. Preservation is only fair in the critical interval of Core 10 and this determination requires further confirmation elsewhere before being unequivocally accepted, as it implies a significant temporal extension for the duration of Subzone P3b at the expense of Subzone $\mathrm{P} 3 \mathrm{a}$; the form is identified here as Igorina sp. aff. I. albeari.

(b) The significantly higher/younger ( $\sim 0.4$ my) extension of the robust, subquadrate $P$. varianta (58.77 Ma vs. 59.2 Ma in BKSA95) into Zone P4 (=FAD of Globanomalina pseudomenardii at $59.4 \mathrm{Ma}$ vs. $59.2 \mathrm{Ma}$ in BKSA95). We have not found this form occurring in younger levels save for a lone occurrence of a couple of individuals of a morphologically similar form in Core 6 in Subzone P4c. This taxon appears to have its HO in Subzones P3b or P4a in DSDP Hole 465 and ODP Hole 758.

(c) The extension of Acarinina subsphaerica into higher stratigraphic levels (i.e. Subzone P4c). We have observed a similar extension (but in reduced numbers) of this taxon to a stratigraphic level within Chron C25n in ODP Hole 690 and to levels correlative to Chron C25n at DSDP Hole 465 and ODP Hole 758 (Indian Ocean) thus annulling its (supposed) HO datum as denominative of Subzone P4b (as defined in BKSA95) within Chron C25r. We have observed forms of similar morphology in the lower Eocene and middle Eocene but are of the opinion that these may be a distinct taxon (Acarinina appressocamerata Blow) as there does not seem to be stratigraphic continuity between the ranges of these two morphotypes.

Thus, while the last common occurrence (LCO) of A. subsphaerica remains a useful event within Chron $\mathrm{C} 25 \mathrm{r}$, it is inappropriate as a criterion for the $\mathrm{P} 4 \mathrm{~b} / \mathrm{P} 4 \mathrm{c}$ zonal biochron boundary. Accordingly we emend the definition of Subzones $\mathrm{P} 4 \mathrm{a}$ and $\mathrm{P} 4 \mathrm{~b}$ in this paper.

Other points of biostratigraphic/biochronologic interest include the following.

(1) The HO/LAD of Praemurica taurica may serve to denote the base/beginning of Subzone/ Subbiochron P1c (defined by the LO/FAD of Globanomalina compressa) inasmuch as the two datum events have been found to coincide (62.87 Ma) in Chron C28n.

(2) The HO of Globoconusa daubjergensis serves to denote the boundary between Subzone P1c and Zone $\mathrm{P} 2$ inasmuch as its LAD coincides with the FAD of Praemurica uncinata (61.37 Ma) near the end of Chron C27r [vs. 61.2 Ma, Chron $\mathrm{C} 27 \mathrm{n}_{(\mathrm{o})}$ in BKSA95], confirming its (much disputed) upper limit and (essential) absence in Zone P2.

(3) The LAD of Igorina pusilla coincides with the FAD of Morozovella velascoensis $(59.75 \mathrm{Ma})$ in Chron C26r.

(4) The LAD of Morozovella conicotruncata coincides with the LAD of Parasubbotina varianta (58.77 Ma) in Chron C26r and lies within subbiochron $\mathrm{P} 4 \mathrm{~b}$ (as redefined here).

(5) The LO/FAD of the earliest acarininid, $A$. strabocella ( $A$. praepentacamerata of Russian authors) is confirmed in lower/early Biozone/ Biochron P3 (60.6 Ma) in early Chron C26r. The radiation of the acarininids in the early part of Biochron P4 (A. acarinata, A. subsphaerica and A. mckannai) is supported.

(6) The HO of Subbotina triloculinoides corresponds with the boundary between Subzones 
$\mathrm{P} 4 \mathrm{~b}$ and $\mathrm{P} 4 \mathrm{c}(56.46 \mathrm{Ma})$ in the upper part Chronozone C25r.

\subsection{Emendation of Subzones P4a and P4b of Zone P4: Gl. pseudomenardii total range zone}

Definition of Zone P4: same as in BKSA95.

P4a: Gl. pseudomenardii/P. variospira concurrent-range subzone (herein defined; emendation of Subzone P4a of BKSA95).

Definition: biostratigraphic interval characterized by the concurrent range of the two nominate taxa between the FAD of Gl. pseudomenardii and the LAD of $P$. variospira.

Magnetochronologic calibration: Chron C26r (mid-) to Chron C26 (mid-).

Estimated age: 59.4-59.2 Ma; late Paleocene (late Selandian).

P4b: A. subsphaerica partial range subzone (herein defined; emendation/redefinition of the $G l$. pseudomenardii/A. subsphaerica concurrent-range subzone (P4a) of BKSA95.

Definition: the partial range of the nominate taxon between the LAD of $P$. variospira and the FAD of $A$. soldadoensis.

Magnetochronologic calibration: Chron C26r (mid-) to Chron C25r (late).

Estimated age: 59.2-56.5 Ma; late Paleocene (late Selandian-Thanetian).

Remarks: the emendation of Subzones P4a and $\mathrm{P} 4 \mathrm{~b}$ made herein has essentially the effect of reversing the stratigraphic extent/duration of the two subzones. Subzones P4a is correlative with Zone NP5, whereas Subzone P4b spans the interval correlative with Zones NP5 (upper part) to NP8 (lower part).

P4c: same as in BKSA95.

Zone P5: $M$. velascoensis interval zone.

Remarks: there have been several attempts to subdivide Zone P5 in order to increase biostratigraphic resolution within/through the stratigraphic interval bracketing [and including the late Paleocene thermal maximum (LPTM)]. Highlights of these recent studies include the following.

(1) Arenillas and Molina (1996) proposed an Ig. laevigata subzone for the lower part of the $M$. velascoensis zone. This was subsequently abandoned in view of the fact that laevigata as recorded by these authors may be a junior synonym of albeari (see Blow, 1979 and Berggren and Norris, 1997).

(2) Pardo et al. (1999) subdivided Zone P5 based on the FAD of $A$. sibaiyaensis and/or $A$. africana. It was denominated a concurrent-range subzone based on the FAD of sibaiyaensis and/or africana at the base of the $\delta^{13} \mathrm{C}$ isotope excursion and the benthic foraminiferal extinction (BFE) and the LAD of velascoensis. A duration of $0.078 \mathrm{my}$ (from $57.78 \mathrm{Ma}$ to $57.7 \mathrm{Ma}$ ) was estimated for this subzone based, supposedly, on the time scale of BKSA95. However, there are several problems with this definition and temporal estimate. (i) A concurrent range (sub)zone is defined on the basis of the biostratigraphic overlap of two taxa between the respective initial and terminal occurrence of each of the two taxa. A. sibaiyaensis and $A$. africana are characteristic of the stratigraphic interval of the $\delta^{13} \mathrm{C}$ excursion (Kelly et al., 1996; now estimated to have spanned $\sim 158 \mathrm{kyr}$; Norris and Röhl, 1999), whereas M. velascoensis extends $\sim 1$ my beyond the $\delta^{13} \mathrm{C}$ excursion (54.7 Ma in the time scale of BKSA95; $54.48 \mathrm{Ma}$ in the revised chronology of Berggren and Aubry, $1998 \mathrm{a}$, p. 31). (ii) The $\delta^{13} \mathrm{C}$ excursion is at $\sim 55.5 \mathrm{Ma}$ (BKSA95); it is not clear how the number $54.78 \mathrm{Ma}$ is derived/estimated for the $\delta^{13}$ $\mathrm{C}$ excursion and/or BEE.

(3) Molina et al. (1999) have proposed a fivefold subdivision of Zone P5 (from the base) into: (a) Morozovella aequa subzone (interval from the $\mathrm{LO}$ of Luterbacheria pseudomenardii to the FO of Morozovella gracilis); (b) Morozovella gracilis subzone (interval from the $\mathrm{FO}$ of $M$. gracilis to the FO of Acarinina berggreni); (c) Acarinina berggreni subzone (interval from the $\mathrm{FO}$ of $A$. berggreni to the FO of A. sibaiyaensis); (d) Acarinina sibaiyaensis subzone (interval from the FO of $A$. sibaiyaensis to the FO of Pseudohastigerina wilcoxensis); (e) Pseudohastigerina wilcoxensis subzone (interval between the FO of $P$. wilcoxensis and the $\mathrm{LO}$ of M. velascoensis).

(4) Speijer et al. (1999) have proposed a threefold subdivision of Zone P5 as follows (from the bottom): (a) Subzone P5a, Globanomalina chapmani interval subzone (interval between the $\mathrm{HO}$ of $M$. pseudomenardii and/or LO of M. subboti- 
Table 7

List of all samples analyzed for magnetostratigraphy and calcareous plankton biostratigraphy and the zonal boundaries between each. Note: in this study, core catchers are located in continuity with the lowest recovered section in a core, in agreement with the current ODP policy. Also several samples analyzed for calcareous nannofossils proved to be out of place (several slides were prepared to rule out laboratory contamination). Dotted line shows intervals of uncertainty around biozonal and magnetostratigraphic boundaries

\begin{tabular}{|c|c|c|c|c|}
\hline Samples & Depth (mbsf) & P zone & NP zone & Polarity \\
\hline $6-1,30-34$ & 98.90 & $\mathrm{P} 4 \mathrm{c}$ & & \\
\hline $6-1,89-91$ & 99.30 & $\mathrm{P} 4 \mathrm{c}$ & NP9 & \\
\hline $6-1,115$ & 99.75 & & & $\mathrm{C} 25 \mathrm{n}$ \\
\hline $6-1,133-135$ & 99.93 & & NP9 & $\mathrm{C} 25 \mathrm{n}$ \\
\hline $6-2,92-95$ & 101.02 & $\mathrm{P} 4 \mathrm{c}$ & NP8 & \\
\hline $6-2,131-133$ & 101.41 & & NP8 & $\mathrm{C} 25 \mathrm{n}$ \\
\hline $6-3,18-20$ & 101.78 & & NP8 & $\mathrm{C} 25 \mathrm{n}$ \\
\hline $6-3,30-34$ & 101.90 & $\mathrm{P} 4 \mathrm{c}$ & NP8 & $\ldots$ \\
\hline $6-3,92-94$ & 102.52 & $\mathrm{P} 4 \mathrm{c}$ & NP8 & $\ldots$ \\
\hline $6-3,136-138$ & 102.96 & $\ldots$ & NP8 & $\mathrm{C} 25 \mathrm{r}$ \\
\hline $6-4,6-8$ & 103.16 & $\ldots$ & NP8 & $\mathrm{C} 25 \mathrm{r}$ \\
\hline $6-4,130-132$ & 104.40 & $\mathrm{P} 4 \mathrm{~b}$ & NP8 & \\
\hline $6-\mathrm{CC}$ & 108.00 & $\mathrm{P} 4 \mathrm{~b}$ & & \\
\hline $7-1,60-64$ & 108.60 & $\mathrm{P} 4 \mathrm{~b}$ & & \\
\hline $7-1,90-92$ & 108.90 & $\mathrm{P} 4 \mathrm{~b}$ & NP8 & \\
\hline $7-1,143-145$ & 109.43 & & NP8 & $\mathrm{C} 25 \mathrm{r}$ \\
\hline $7-2,30-32$ & 109.80 & & NP8 & $\mathrm{C} 25 \mathrm{r}$ \\
\hline $7-2,104-106$ & 110.54 & $\mathrm{P} 4 \mathrm{~b}$ & & \\
\hline $7-2,106-108$ & 110.58 & & NP8 & \\
\hline $7-3,10-12$ & 111.10 & & ?NP8 & $\mathrm{C} 25 \mathrm{r}$ \\
\hline $7-3,92-94$ & 111.92 & $\mathrm{P} 4 \mathrm{~b}$ & NP8 & \\
\hline $7-4,120-122$ & 113.70 & $\ldots$ & ?NP8 & $\mathrm{C} 25 \mathrm{r}$ \\
\hline $7-4,130-132$ & 113.80 & $\mathrm{P} 4 \mathrm{a}$ & NP8 & \\
\hline $7-5,10-12$ & 114.10 & & NP8 & $\mathrm{C} 25 \mathrm{r}$ \\
\hline $7-5,130-132$ & 115.30 & $\mathrm{P} 4 \mathrm{a}$ & NP8 & \\
\hline $7-6,86-88$ & 116.36 & & ?NP8 & $\mathrm{C} 25 \mathrm{r}$ \\
\hline $7-6,130-132$ & 116.80 & $\mathrm{P} 4 \mathrm{a}$ & NP8 & \\
\hline $7-\mathrm{CC}$ & 117.30 & $\mathrm{P} 4 \mathrm{a}$ & & \\
\hline $8-1,120-124$ & 118.50 & $\mathrm{P} 4 \mathrm{a}$ & & \\
\hline $8-1,136-138$ & 118.66 & $\mathrm{P} 4 \mathrm{a}$ & ?NP8 & \\
\hline $8-2,136-138$ & 120.16 & indet. (rad. ooze) & ?NP8 & \\
\hline $8-2,141-143$ & 120.21 & & NP8 & $\mathrm{C} 25 \mathrm{r}$ \\
\hline $8-3,65-67$ & 120.95 & & NP7 & $\mathrm{C} 25 \mathrm{r}$ \\
\hline $8-3,132-134$ & 121.62 & & NP7 & \\
\hline $8-3,136-138$ & 121.68 & P4a (rad. ooze) & & \\
\hline $8-4,26-28$ & 122.06 & & NP7 & $\mathrm{C} 25 \mathrm{r}$ \\
\hline $8-4,119$ & 122.99 & & $\ldots$ & $\mathrm{C} 26 \mathrm{n}$ \\
\hline $8-4,136-138$ & 123.16 & P4a (rad. ooze) & NP6 & \\
\hline $8-5,15-17$ & 123.45 & & NP6 & $\mathrm{C} 26 \mathrm{n}$ \\
\hline $8-5,67-69$ & 123.97 & & NP6 & $\mathrm{C} 26 \mathrm{n}$ \\
\hline $8-5,126$ & 124.56 & & & $\mathrm{C} 26 \mathrm{n}$ \\
\hline $8-5,136-138$ & 124.66 & indet. (rad. ooze) & NP6 & $\ldots$ \\
\hline $8-\mathrm{CC}$ & 126.9 & P4a (rad. ooze) & $\ldots$ & $\ldots$ \\
\hline $9-1,8-10$ & 127.43 & & NP5 & $\mathrm{C} 26 \mathrm{r}$ \\
\hline $9-1,75-77$ & 128.10 & & NP5 & $\mathrm{C} 26 \mathrm{r}$ \\
\hline $9-1,136-138$ & 128.26 & P4a (rad. ooze) & NP5 & \\
\hline $9-2,47-49$ & 129.32 & & NP5 & $\mathrm{C} 26 \mathrm{r}$ \\
\hline $9-2,136-138$ & 129.76 & P4a (rad. ooze) & NP5 & \\
\hline $9-3,20-22$ & 130.55 & & NP5 & $\mathrm{C} 26 \mathrm{r}$ \\
\hline
\end{tabular}


Table 7 (continued)

\begin{tabular}{|c|c|c|c|c|}
\hline Samples & Depth (mbsf) & P zone & NP zone & Polarity \\
\hline $9-3,136-138$ & 131.28 & indet. (rad. ooze) & NP5 & \\
\hline $9-4,118-120$ & 133.03 & & NP5 & $\mathrm{C} 26 \mathrm{r}$ \\
\hline $9-4,136-138$ & 132.76 & P4a (rad. ooze) & NP5 & \\
\hline $9-5,120-122$ & 134.10 & & NP5 & $\mathrm{C} 26 \mathrm{r}$ \\
\hline $9-5,136-138$ & 134.26 & P4a (rad. ooze) & NP5 & \\
\hline $9-6,58-60$ & 134.98 & & NP5 & $\mathrm{C} 26 \mathrm{r}$ \\
\hline $9-6,136-138$ & 135.78 & $\mathrm{P} 4 \mathrm{a}$ & NP5 & \\
\hline $9-\mathrm{CC}$ & 136.40 & $\mathrm{P} 3 \mathrm{~b}$ & & \\
\hline $10-1,108-110$ & 137.48 & & NP5 & $\mathrm{C} 26 \mathrm{r}$ \\
\hline $10-1,136-138$ & 137.76 & $\mathrm{P} 3 \mathrm{~b}$ & NP5 & \\
\hline $10-2,73-75$ & 138.63 & & NP5 & $\mathrm{C} 26 \mathrm{r}$ \\
\hline $10-2,136-138$ & 139.26 & $\mathrm{P} 3 \mathrm{~b}$ & NP4 & \\
\hline $10-3,10-14$ & 139.50 & $\mathrm{P} 3 \mathrm{~b}$ & & \\
\hline $10-3,43-45$ & 139.83 & & NP4 & $\mathrm{C} 26 \mathrm{r}$ \\
\hline $10-3,124-126$ & 140.64 & P3b & NP4 & \\
\hline $10-3,136-138$ & 140.76 & P3b & & \\
\hline $10-4,44-46$ & 141.34 & $\ldots$ & NP4 & $\mathrm{C} 26 \mathrm{r}$ \\
\hline $10-4,136-138$ & 142.26 & $\mathrm{P} 3 \mathrm{a}$ & NP4 & \\
\hline $10-5,24-28$ & 142.64 & $\mathrm{P} 3 \mathrm{a}$ & & \\
\hline $10-5,50-52$ & 142.90 & & NP4 & $\mathrm{C} 26 \mathrm{r}$ \\
\hline $10-5,136-138$ & 143.76 & P3a & NP4 & \\
\hline $10-6,112-114$ & 145.02 & & NP4 & $\mathrm{C} 26 \mathrm{r}$ \\
\hline $10-6,136-138$ & 145.26 & $\mathrm{P} 3 \mathrm{a}$ & NP4 & \\
\hline $10-\mathrm{CC}$ & 145.70 & $\mathrm{P} 3 \mathrm{a}$ & & \\
\hline $11-1,86-90$ & 146,58 & $\mathrm{P} 3 \mathrm{a}$ & & \\
\hline $11-1,109-111$ & 146.79 & & NP4 & $\mathrm{C} 26 \mathrm{r}$ \\
\hline $11-1,136-138$ & 147.06 & $\mathrm{P} 3 \mathrm{a}$ & NP4 & \\
\hline $11-2.58$ & 147.78 & & & $\mathrm{C} 26 \mathrm{r}$ \\
\hline $11-2,110112$ & 148.30 & & Indet. & $\mathrm{C} 27 \mathrm{n}$ \\
\hline $11-2,118120$ & 148.38 & $\mathrm{P} 3 \mathrm{a}$ & (Cret.) & \\
\hline $11-3,3032$ & 149.00 & $\mathrm{P} 2$ & & \\
\hline $11-3,7779$ & 149.47 & & ?NP4 & $\mathrm{C} 27 \mathrm{n}$ \\
\hline $11-3,136138$ & 150.06 & $\mathrm{P} 2$ & NP4 & \\
\hline $11-4,3739$ & 150.57 & $\ldots$ & (NP6) & $\mathrm{C} 27 \mathrm{n}$ \\
\hline $11-4,58$ & 150.78 & $\ldots$ & & $\mathrm{C} 27 \mathrm{r}$ \\
\hline 11-4, 107109 & 151.27 & $\ldots$ & NP4 & $\mathrm{C} 27 \mathrm{r}$ \\
\hline $11-4,136138$ & 151.56 & P1c & NP4 & \\
\hline $11-\mathrm{CC}$ & 155.00 & P1c & & \\
\hline $12-1,9092$ & 155.90 & $\mathrm{P} 1 \mathrm{c}$ & & \\
\hline $12-1,9698$ & 155.96 & & ?NP4 & $\mathrm{C} 27 \mathrm{r}$ \\
\hline $12-1,136138$ & 156.36 & & NP4 & \\
\hline $12-2,57$ & 156.55 & & NP4 & $\mathrm{C} 27 \mathrm{r}$ \\
\hline $12-2,28$ & 156.78 & & $\ldots$ & $\mathrm{C} 27 \mathrm{r}$ \\
\hline $12-2,136138$ & 157.86 & & NP3 & $\ldots$ \\
\hline $12-3,2022$ & 158.20 & $\mathrm{P} 1 \mathrm{c}$ & & $\ldots$ \\
\hline $12-3,9496$ & 158.94 & & NP3 & $\mathrm{C} 28 \mathrm{n}$ \\
\hline $12-3,136138$ & 159.36 & $\mathrm{P} 1 \mathrm{c}$ & NP3 & \\
\hline $12-4,9193$ & 160.41 & $\ldots$ & NP3 & $\mathrm{C} 28 \mathrm{n}$ \\
\hline $12-4,136138$ & 160.86 & $\mathrm{P} 1 \mathrm{~b}$ & (NP7) & $\ldots$ \\
\hline $12-5,3032$ & 161.30 & $\mathrm{P} 1 \mathrm{~b}$ & & $\ldots$ \\
\hline $12-5,7476$ & 161.74 & & NP3 & $\mathrm{C} 28 \mathrm{r}$ \\
\hline $12-5,136138$ & 162.38 & & NP3 & $\ldots$ \\
\hline $12-6,61$ & 163.11 & & & $\mathrm{C} 29 \mathrm{n}$ \\
\hline $12-6,108110$ & 163.58 & $\mathrm{P} 1 \mathrm{~b}$ & NP3 & $\ldots$ \\
\hline
\end{tabular}


Table 7 (continued)

\begin{tabular}{|c|c|c|c|c|}
\hline Samples & Depth (mbsf) & P zone & NP zone & Polarity \\
\hline $12-\mathrm{CC}$ & 164.10 & P1b & $\ldots$ & $\ldots$ \\
\hline $13-1,134136$ & 165.94 & $\mathrm{P} 1 \mathrm{~b}$ & $\ldots$ & $\ldots$ \\
\hline $13-1,136138$ & 165.96 & & NP2 & $\ldots$ \\
\hline $13-2,3840$ & 166.48 & $\mathrm{P} 1 \mathrm{~b}$ & & $\ldots$ \\
\hline $13-2,4951$ & 166.59 & & NP2 & $\ldots$ \\
\hline $13-2,100101.5$ & 167.10 & $\mathrm{P} 1 \mathrm{~b}$ & & $\ldots$ \\
\hline 13-2, 105107 & 167.15 & & NP2 & $\ldots$ \\
\hline $13-2,109110.5$ & 167.19 & $\mathrm{P} 1 \mathrm{~b}$ & & $\ldots$ \\
\hline $13-2,120121.5$ & 167.30 & P1a & & $\ldots$ \\
\hline $13-2 \quad 130 \quad 133$ & 167.40 & Pla & & $\ldots$ \\
\hline $13-2,136^{\mathrm{a}}$ & $167.46^{\mathrm{a}}$ & & & $\mathrm{C} 29 \mathrm{r}$ \\
\hline $132,140-142$ & 167.50 & P1a & & \\
\hline $132,147^{\mathrm{a}}$ & $167.57^{\mathrm{a}}$ & & & $\mathrm{C} 29 \mathrm{r}$ \\
\hline $133,06^{\mathrm{a}}$ & $167.66^{\mathrm{a}}$ & & & $\mathrm{C} 29 \mathrm{r}$ \\
\hline $133,10-12$ & 167.70 & P1a & NP2 & \\
\hline $133,15^{\mathrm{a}}$ & $167.75^{a}$ & & & $\mathrm{C} 29 \mathrm{r}$ \\
\hline $133,28-30$ & 167.88 & P1a & & \\
\hline $133,30-32$ & 167.90 & Pla & & \\
\hline $13-3,47^{\mathrm{a}}$ & $168.07^{\mathrm{a}}$ & $\ldots$ & & $\mathrm{C} 29 \mathrm{r}$ \\
\hline $13-3,54^{\mathrm{a}}$ & $168.14^{\mathrm{a}}$ & $\ldots$ & & $\mathrm{C} 29 \mathrm{r}$ \\
\hline $13-3,64^{\mathrm{a}}$ & $168.24^{\mathrm{a}}$ & $\ldots$ & & $\mathrm{C} 29 \mathrm{r}$ \\
\hline $13-3,67$ & 168.27 & $\ldots$ & & $? \mathrm{C} 29 \mathrm{r}$ \\
\hline $13-3,72^{\mathrm{a}}$ & $168.32^{\mathrm{a}}$ & $\ldots$ & & ?C29r \\
\hline $13-3,84^{\mathrm{a}}$ & $168.44^{\mathrm{a}}$ & $\ldots$ & & ?C29r \\
\hline $13-3,99-101$ & 168.59 & $\ldots$ & Cret. & \\
\hline $13-3,105^{\mathrm{a}}$ & $168.65^{\mathrm{a}}$ & $\ldots$ & & ?C29r \\
\hline $13-3,115^{\mathrm{a}}$ & $168.75^{\mathrm{a}}$ & $\ldots$ & & $\mathrm{C} 30 \mathrm{n}$ \\
\hline $13-4,42$ & 169.52 & $\ldots$ & & $\mathrm{C} 30 \mathrm{n}$ \\
\hline $13-4,62-64$ & 169.72 & upper Cretaceous & (NP3) & $\ldots$ \\
\hline $13-5,118$ & 171.78 & id. & & $\mathrm{C} 30 \mathrm{r}$ \\
\hline $13-6,86$ & 172.96 & id. & & $\mathrm{C} 31 \mathrm{n}$ \\
\hline $14-1,138$ & 174.98 & id. & & $\mathrm{C} 31 \mathrm{n}$ \\
\hline $14-2,109$ & 176.19 & id. & & $\mathrm{C} 31 \mathrm{n}$ \\
\hline
\end{tabular}

${ }^{a}$ Samples analyzed by Larson and Opdyke (1979).

nae); (b) Subzone P5b, Morozovella allisonensis total range subzone (total range of nominate taxon, restricted to the interval of the $\delta^{13} \mathrm{C}$ excursion); (c) Subzone P5c, Globanomalina luxorensis subzone (interval between the $\mathrm{HO}$ of $M$. allisonensis and the $\mathrm{HO}$ of $M$. velascoensis).

We refrain from subdividing Zone P5 at this time. We agree that the distribution of the 'excursion taxa' (M. allisonensis, A. sibaiyaensis and $A$. africana) and the LO of Pseudohasterigerina represent a useful set of datums within the middle of Zone P5 and that further subdivision may be possible as detailed studies are carried out at many sites. However, we consider it more useful to recognize these biostratigraphic events as datums within Zone P5 rather than use them to formally define subzones until their reliability has been validated. For example the LO of Pseudohastigerina has been variably reported to occur from mid-Zone P5 to the P5/6 zonal boundary and in some instances even higher.

A list of all samples studied for calcareous plankton biostratigraphy and measured for magnetostratigraphy in this study is shown in Table 7, together with the boundaries between bio- and magnetostratigraphic zones. A regional comparison of Paleocene (sub)tropical planktonic foraminiferal zonal schemes is shown in Fig. 12. 


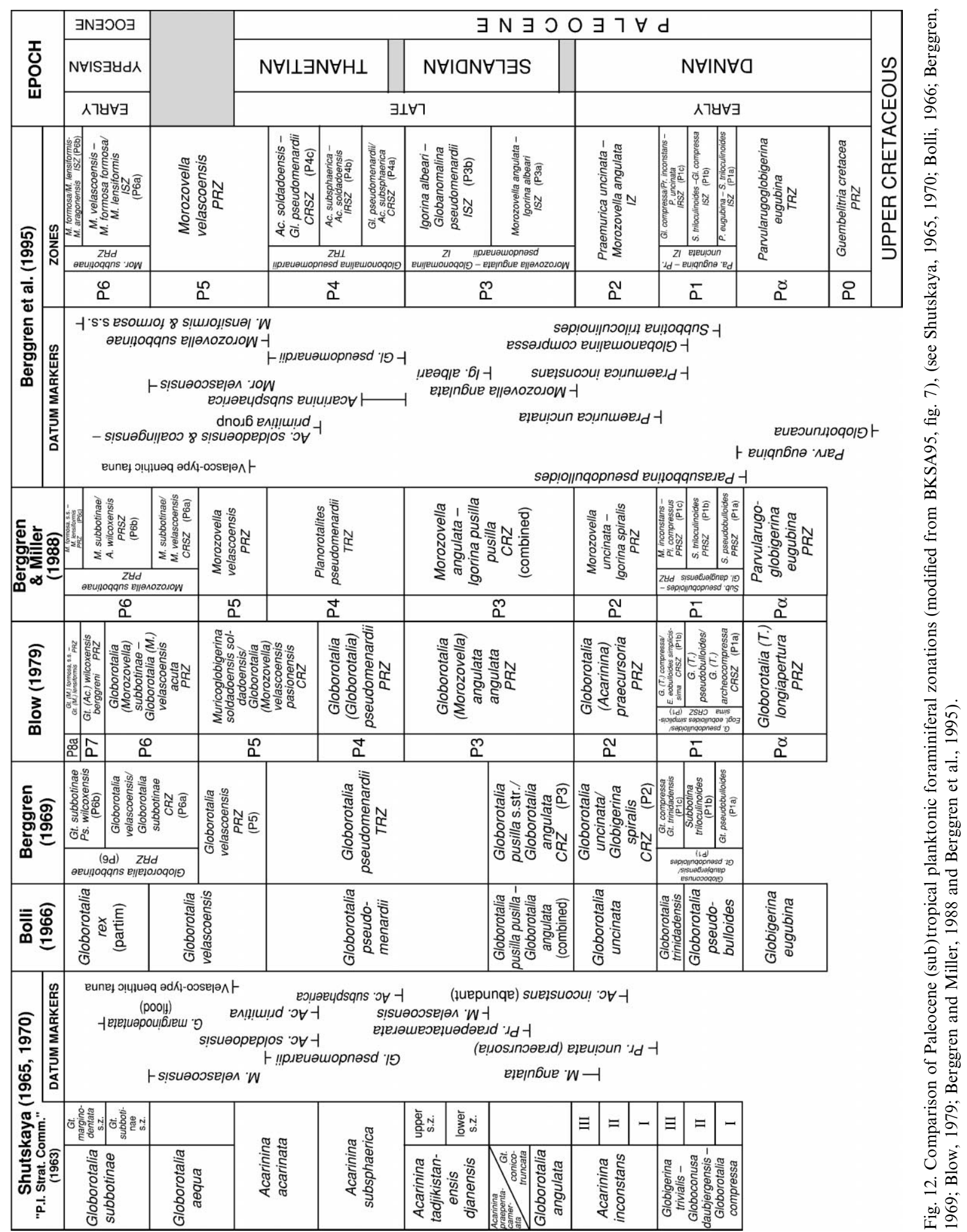




\subsection{Calcareous nannoplankton biochronology}

The recovery at Site 384 of a thick Paleocene section with a clear magnetostratigraphic signature may help stabilize Paleocene calcareous biochronology as correlations between calcareous nannofossil datums and magnetic reversals are straightforward. As discussed in BKSA95, the reliability of Paleocene calcareous nannofossil biochronology has been questioned based on the interpretation that apparent inconsistencies in the correlation between the LOs and HOs of zonal markers and magnetic reversals reflect diachrony (e.g. Wei and Wise, 1989). One of us (MPA in BKSA95; see also Aubry, 1995) has shown that undeciphered unconformities in numerous deep sea sections were in fact the reason for these apparent discrepancies. The correlations established in Hole 384 are essentially the same as those established by Monechi and Thierstein (1985) in the sections near Gubbio. However, the Paleocene section at Site 384 is much thicker than the latter sections (the interval from the top of Magnetozone $\mathrm{C} 25 \mathrm{n}$ to the $\mathrm{K} / \mathrm{P}$ boundary is $\sim 70 \mathrm{~m}$ thick in Hole 384 compared to $\sim 15 \mathrm{~m}$ for the Botaccione section and $\sim 30 \mathrm{~m}$ for the Contessa Highway section) and there is no ambiguous interpretation of the magnetic reversal pattern in Hole 384 (except for the lowermost part of the section largely due to a recovery gap). In the Gubbio sections, Chrons $\mathrm{C} 29 \mathrm{n}$ and C28n are undifferentiated and Chron C26n is poorly delineated due to the occurrence of 1 (Bottaccione) or 2 (Contessa Highway) intervening magnetozones with reversed polarity. In addition, Chron $\mathrm{C} 25 \mathrm{n}$ is extremely thin in the Bottacione section. Based on Hole 384, the following correlations concerning the Paleocene zonal markers are established.

1. The FAD of C. danicus lies in late Chron C29n. This datum, inadvertently located in Chron C28r in BKSA95, is further discussed below.

2. The FAD of E. macellus lies in earliest Chron C27r (also supported by the data from Gubbio and from DSDP Sites 527 and 516 (see discussion in BKSA95). [A short clarification is needed here lest it appear that the discussion in BKSA95 on the Paleocene biochronology and herein are contradictory.] In BKSA95 the corre- lations between magnetic reversals and LO of E. macellus and H. kleinpelli in the Gubbio sections are those given in Wei and Wise (1989) and different from those given here that were taken directly out of the publication by Monechi and Thierstein (1985).

3. The FAD of $F$. tympaniformis lies in late early Chron C26r (also supported by the data from the Gubbio sections and Hole 752A and 762C; see BKSA95).

4. The FAD of H. kleinpelli lies close to the Chron C26r/C26n reversal. However, because of the $\sim 2 \mathrm{~m}$ interval of non-recovery between Cores 8 and 9 in Hole 384, and the relatively large sampling gap $(>2.7 \mathrm{~m})$ around the core break, it is not possible to determine precisely from Hole 384 where the LAD of the species occurred relative to the magnetic reversal. The magnetobiostratigraphic correlation established in Hole 527 was used in BKSA95. In the Contessa Highway section, the LO of the species lies in the middle of the lower of three normal magnetozones interpreted as representing Chron C26n, and in the Bottaccione section, it occurs in the younger of the two normal magnetozones identified as Chron C26n, which calls into question the identification of Chron C26n in these sections (see BKSA95).

5. The FAD of $D$. mohleri lies very close to the Chron C26n/C25r (as supported by data from Hole 762C).

6. The FAD of $H$. riedelii lies in early Chron C25r. Whereas the location of the base of Zone NP8 in Chron $\mathrm{C} 25 \mathrm{r}$ has been well established from magnetobiostratigraphic correlations in epicontinental sediments (e.g. Aubry et al., 1986), Hole 384 is the first section that permits us to estimate the age of this event.

7. The FAD of D. multiradiatus lies in Chron $\mathrm{C} 25 \mathrm{n}$, and is one of the earliest reliably established Paleocene datums.

The FAD of Chiasmolithus danicus requires some discussion here. This event has been located in Chron C28r and C28n in different sections (see BKSA95). However, interpretation of the magnetostratigraphy in the sections that support such location is dubious or controversial. In the Gubbio sections, the Chrons C28n and 29n are 
Table 8

Compared identification of the magnetozones delineated in the oldest Paleocene sediments recovered from Holes 527 and 528, and location of critical biostratigraphic datums. Note that the intervals between 393.50 and 397.50 mbsf in Hole 528 and between 261.40 and 265.5 in Hole 527 are recovery gaps. Locations of biostratigraphic datums in the holes are averaged depths given in Shackleton et al. (1984)

\begin{tabular}{|c|c|c|c|c|c|c|c|}
\hline \multicolumn{4}{|l|}{ Site 528} & \multicolumn{4}{|l|}{ Site 527} \\
\hline $\begin{array}{l}\text { Normal } \\
\text { magnetozone } \\
(\mathrm{mbsf})\end{array}$ & $\begin{array}{l}\text { Shackleton } \\
\text { et al. (1984) }\end{array}$ & $\begin{array}{l}\text { Chave } \\
(1984)\end{array}$ & Datums & $\begin{array}{l}\text { Normal } \\
\text { magnetozone } \\
\text { (mbsf) }\end{array}$ & $\begin{array}{l}\text { Shackleton } \\
\text { et al. (1984) }\end{array}$ & $\begin{array}{l}\text { Chave } \\
(1984)\end{array}$ & Datums \\
\hline 391.58 to $? \sim 392$ & Chron C27n & Chron C28n & $\begin{array}{l}\text { LO E. macellus } \\
\text { at } 390.50 \mathrm{mbsf}\end{array}$ & 258.75 to 260.77 & Chron C27n & Chron C28n & $\begin{array}{l}\text { LO E. macellus } \\
\text { at } 268.03 \mathrm{mbsf}\end{array}$ \\
\hline$\sim 392$ to $\sim 398$ & & Chron C29n & $\begin{array}{l}\text { LO C. danicus } \\
\text { at } 395.20 \mathrm{mbsf}\end{array}$ & 267.41 to 272.72 & Chron C28n & Chron C29n & $\begin{array}{l}\text { LO } C \text {. danicus } \\
\text { at } 271.10 \mathrm{mbsf}\end{array}$ \\
\hline 399.47 to 405.97 & Chron C29n & Chron C29n & & 273.72 to 278.02 & Chron C29n & Chron C29n & \\
\hline
\end{tabular}

undifferentiated, so that correlating the LO of $C$. danicus to one chron or the other is not possible (the LO is located at about mid-point of a normal magnetozone interpreted as Chrons $\mathrm{C} 28 \mathrm{n}$ and $\mathrm{C} 29 \mathrm{n}$ in both sections; Monechi and Thierstein, 1985). Very different interpretations of the magnetostratigraphy of the lowermost Paleocene sediments recovered from Walvis Ridge Sites 525-529 have been given (compare Chave, 1984; Shackleton et al., 1984; Manivit and Feinberg, 1984). Whereas Shackleton et al. (1984) interpreted the normal polarity magnetozones that occur between 278.02 and $258.75 \mathrm{mbsf}$ in Hole 527 as corresponding to Chrons C29n, C28n and C27n, Chave (1984) interpreted the lower two as representing Chron C29n and the upper one as Chron C28n (Table 8). Similarly, the normal magnetozone between $391.58 \mathrm{mbsf}$ and $393.50 \mathrm{mbsf}$ in Hole 528 was interpreted as representing Chron $\mathrm{C} 27 \mathrm{n}$ by Shackleton et al. (1984) but Chron C28n by Chave (1984), respectively. The proximity of the LO of E. macellus to the magnetic reversal boundary at $391.58 \mathrm{mbsf}$ in Hole 528 and at $258.75 \mathrm{mbsf}$ in Hole 527 indicates that this boundary corresponds to the Chron $\mathrm{C} 28 \mathrm{n} / \mathrm{C} 27 \mathrm{r}$ reversal (in agreement with the magnetostratigraphic interpretation by Chave (1984). It follows that the LO of C. danicus is clearly associated with Chron C29n, not Chron C28n in Hole 527. Because of the large coring gap in Hole 528, the LO of C. danicus in this hole is poorly delineated; Chron C28r was not recovered, and therefore this section provides no evidence of a correlation between the $\mathrm{LO}$ of $C$. danicus and Chron C28r. Unless there is an undeciphered problem with our delineation of the top of Chron C29n in Hole 384, location of the FAD of $C$. danicus in late Chron $\mathrm{C} 29 \mathrm{n}$ is firm and supported by magnetobiostratigraphic correlations in Site 527. This will thus require reinterpretation of the lowermost Paleocene magnetostratigraphic record as at DSDP Site 577 and ODP Site 762 (used in BKSA95), where Chron C28n may not be represented.

The precision in our age estimates of the biochronologic events discussed above (Table 9) varies with different parts of the Site 384 section, and is considerably reduced when biostratigraphic datums occur in the vicinity of recovery gap. Thus, age estimates are given here with age uncertainty so as to reflect the different degrees of precision obtained for different events. However, the uncertainty reflects only the stratigraphic resolution obtained for the biostratigraphic events. The uncertainty linked to the stratigraphic position of the magnetic reversals has not been taken into account.

Age estimates are established for a few secondary markers such as Sphenolithus primus, Sphenolithus anarrhopus and Discoaster okadai. Diversity is rather low at all levels in the Paleocene of Site 384, and this is not a suitable site for establishing a numerical chronology for calcareous nannofossil taxa other than the marker species. 
Table 9

Paleocene calcareous nannoplankton biochronology as deduced from magnetobiostratigraphic correlations in Hole 384

\begin{tabular}{lcccc}
\hline Events & Depth in the core (mbsf) & Mid-level & Age estimate (Ma) & Age uncertainty (my) \\
\hline FAD D. multiradiatus & $99.93-101.57$ & 100.75 & 56.3 & \pm 0.05 \\
FAD D. okadai & $109.43-109.80$ & 109.61 & 56.82 & \pm 0.01 \\
FAD D. nobilis & $109.43-109.80$ & 109.61 & 56.82 & \pm 0.01 \\
FAD H. riedeli & $120.21-120.95$ & 120.58 & 57.45 & \pm 0.02 \\
FAD D. mohleri & $122.28-123.09$ & 122.68 & 57.47 & \pm 0.05 \\
FAD S. anarrhopus & $124.66-127.43$ & 126.04 & 57.92 & \pm 0.18 \\
FAD H. kleinpelli & $126.90-127.43$ & 127.16 & 58.07 & \pm 0.04 \\
FAD T. eminens & $134.26-134.98$ & 134.62 & 59.06 & \pm 0.05 \\
FAD F. bitectus & $134.98-135.78$ & 135.38 & 59.16 & \pm 0.05 \\
FAD C. consuetus & $138.63-139.26$ & 138.94 & 59.72 & \pm 0.04 \\
FAD F. tympaniformis & $138.63-139.26$ & 138.94 & 59.72 & \pm 0.04 \\
FAD S. primus & $145.26-146.79$ & 146.02 & 60.66 & \pm 0.10 \\
FAD F. ulii & $146.79-147.06$ & 146.92 & 60.78 & \pm 0.02 \\
FAD E. macellus & $156.99-157.54$ & 157.26 & 62.6 & \pm 0.06 \\
FAD C. danicus & $163.58-163.60$ & 163.59 & 64.23 & - \\
\hline
\end{tabular}

\subsection{Correlations with radiolaria}

Biosiliceous (predominantly radiolarian) sediments occur sporadically but persistently over the interval of Cores 11 to 6 spanning the biostratigraphic interval of Zones P1c to P4c (as modified herein) and Zones NP4 to NP9. Radiolarian oozes are particularly common in Cores 9-6; dissolution of the calcareous microfossils is strong in some samples in Cores 9 to 6 , and the biosiliceous component may exceed $90 \%$ of the coarse fraction in some intervals (Boersma et al., 1979).

Nishimura (1987) defined a mid-upper Paleocene Bekomia campechensis Zone [below the standard uppermost Paleocene Bekomia bidartensis Zone (Foreman, 1973) and including most of the interval between the Cretaceous/Paleogene System boundary and the B. bidartensis zone referred to by Sanfilippo et al. (1985) as the 'unzoned interval'] based on her investigations on DSDP Hole 603 (lower continental rise of North America, off North Carolina, $\sim 35^{\circ} \mathrm{N}$ ). A subsequent, more detailed, investigation of DSDP Hole 384 led to a three-fold subdivision of the $B$. campechensis zone (Nishimura, 1992).

Sanfilippo and Nigrini (1998) evaluated all available upper Paleocene-lower Eocene DSDP/ODP radiolarian biostratigraphies. They re-examined material from DSDP Hole 384 and adjusted Nishimura's (1992) placement of the campechensis/bidartenesis zonal boundary to between samples 7-6, 62-66 $\mathrm{cm}$ and 7-6, 119$125 \mathrm{~cm}$, which is correlative with a level within Subzone P4c (as modified in this paper) and Zone NP8 (Aubry, this paper). Correlation of Nishimura's (1987, 1992) B. campechensis zone (and subzones) to the 'standard' calcareous planktonic zones is shown in Fig. 13.

\section{Conclusions}

DSDP Hole 384 contains one of the most complete and high quality magnetic polarity Paleocene stratigraphic records in an oceanic setting. Yet this record has remained undocumented for 20 years save for the preliminary studies by Larson and Opdyke (1979) in the Initial Reports of DSDP Leg 43 (Tucholke et al., 1979) which demonstrated the presence of Chrons 31 to 28. The Paleocene part of the calcareous plankton magnetobiochronology of the recently revised Cenozoic IMBS (BKSA95, fig. 1) incorporated data from ODP Holes 465 and 758, as well (Berggren and Norris, 1997), together with additional information from other deep sea sites and land sections (e.g. Gubbio sections, inter alia) but was based primarily on data from DSDP Hole 


\section{PALEOCENE TIME SCALE}

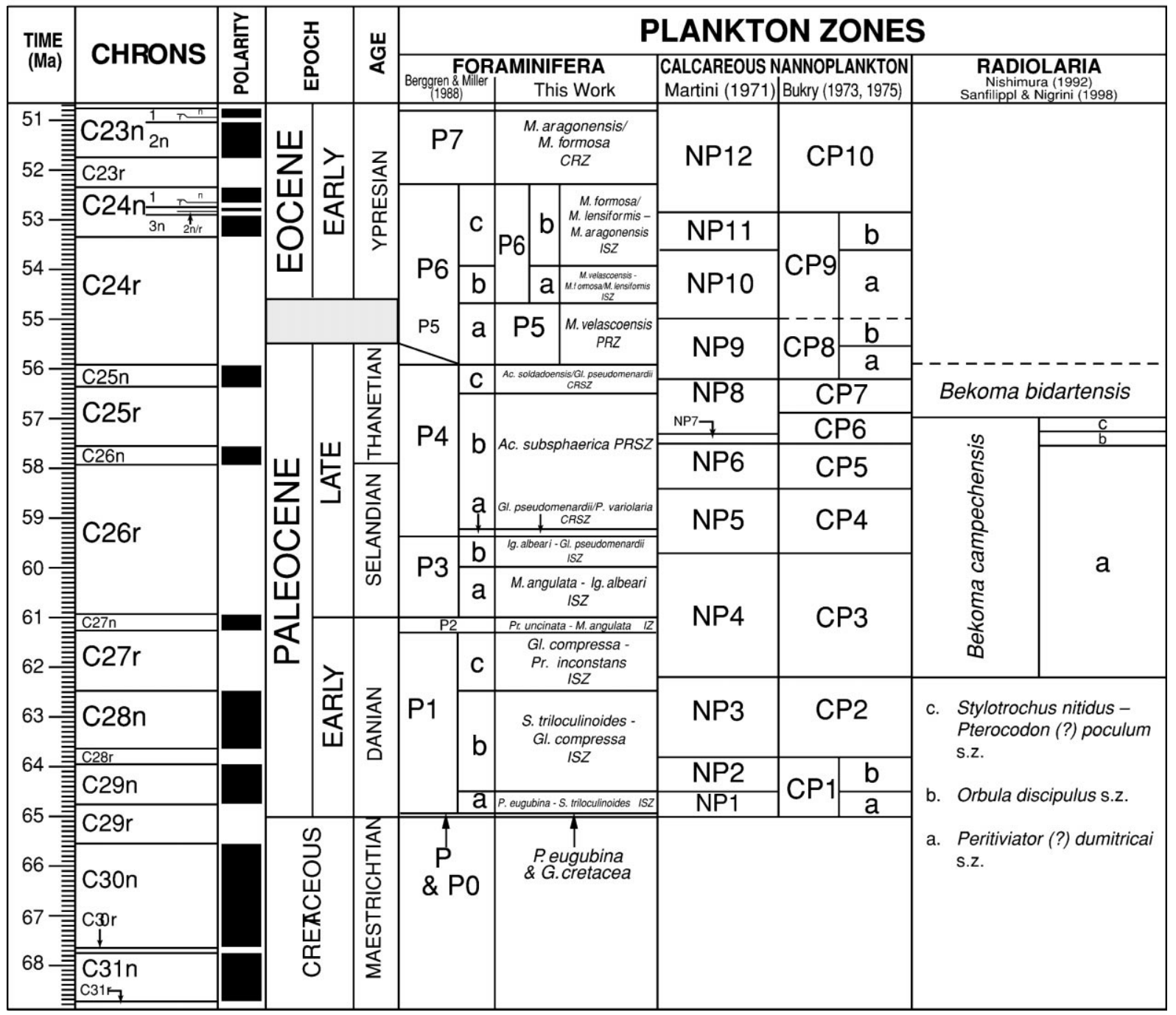

Fig. 13. The Paleocene time scale. The relatively broad gray band spanning the interval between $\sim 54.4$ to 55.5 Ma reflects current opinion on the position of the Paleocene/Eocene boundary. Taken at the base of the type Ypresian in the Belgian Basin or the base of the London Clay Formation in the London-Hampshire Basin its position would be at 54.4 Ma (Aubry, 1996; see discussion in Aubry, submitted). Planktonic foraminiferal specialists commonly use the P5/P6 boundary ( $\sim 54.7$ Ma) and calcareous nannoplankton specialists the NP9/NP10 zonal boundary $(\sim 55.0 \mathrm{Ma})$ as denotative of the boundary for purpose of correlation. More recently the major $\delta^{13} \mathrm{C}$ spike at $\sim 55.5 \mathrm{Ma}$ has been suggested as providing a useful means of correlation between marine and terrestrial stratigraphies (see discussion in Berggren and Aubry, 1998b; Aubry, submitted). Lacking a clearly defined global stratotype section and point (GSSP), the Paleocene/Eocene boundary awaits an unequivocal definition (IGCP Project 308). For the methodology used in constructing this IMBS and the GPTS (CK95) on which it is based the reader is referred to BKSA95. Modified from BKSA95, fig. 1. Note modified definition and chronology of Zone P4 and its subzonal constituents vs. BKSA95 (see text for further discussion). 
384. In this paper we have documented the paleomagnetic polarity stratigraphy of Chrons C31 (late Cretaceous: Maastrichtian) to C25 (late Paleocene: Thanetian). We have integrated the magnetostratigraphy and calcareous plankton biostratigraphy (planktonic foraminifera and calcareous nannoplankton) at DSDP Site 384 and calibrated it to the GPTS of CK95. The result is an IMBS for the Paleocene (Fig. 13) which is slightly modified from BKSA95, fig. 1 to reflect slightly modified age estimates of several planktonic foraminiferal datum events based on Quillévéré (1996) and more recent studies. It can be seen that whereas Site 384 permits a firm correlation of magnetic and biologic events, the numerical chronology for these events will need to be refined as better stratigraphic resolution (better recovery around critical intervals) becomes possible. However, once the biozonal boundaries are suitably correlated to the magnetic reversals, Paleocene numerical biochronology can be pieced together based on the best records of discrete magnetic polarity intervals from different sites. We have also added/integrated the Paleocene radiolarian zonation developed by Nishimura (1992; see also Sanfilippo and Nigrini, 1998) to this scheme (Fig. 13).

\section{Acknowledgements}

We acknowledge our gratitude to the many colleagues and friends who have in one way or another engaged in an ongoing dialogue regarding improvements to the current Cenozoic IMBS (and in particular to the Paleocene part), brought to our attention errors/oversights in BKSA95 and offered constructive comments on draft versions of this paper, in particular, T.J. Bralower, R. Fleisher, K.G. Miller. This research was supported by a consortium of oil companies (AMOCO, BP, CHEVRON, EXXON, UNOCAL) (WAB), various NSF Grants (DVK), OCE (RDN) and a student award from France (FQ). This is Woods Hole Oceanographic Institution Contribution Number 9998, Lamont-Doherty Earth Observatory of Columbia University Contribution No. 6049, and Institut des Sciences de l'Evolution.

\section{Appendix 1}

\section{Identification of Chrons C30 and C31 has been based on the following data.}

(1) Thierstein and Okada (1979, table 1, p. 603) show both Micula mura (common) and Nephrolithus frequens (discontinuous) extending throughout Core 13 down to $173.6 \mathrm{~m}$ and $172.0 \mathrm{~m}$, respectively. Okada and Thierstein (1979, table 3C, p. 518) show Lithraphidites quadratus extending from $185 \mathrm{~m}$ to the $\mathrm{K} / \mathrm{P}$ boundary at $168 \mathrm{~m}$. The FAD of Abathomphalus mayaroensis occurs at 175 m (McNulty, 1979, p. 489).

(2) Normal/reversed and reversed/normal polarity boundaries are shown at $172.37 \mathrm{mbsf}$ and 170.65 mbsf, respectively in this study (see above). These reversals have been interpreted as Chron $31 \mathrm{n}_{(\mathrm{y})}$ and $\mathrm{C} 30 \mathrm{n}_{(\mathrm{o})}$, respectively (Larson and Opdyke, 1979, p. 787; this paper).

(3) This implies the initial appearance of $M$. mura, guide form for the eponymous Zone NC23, near the top of Chron $\mathrm{C} 31 \mathrm{n}$ with an estimated age of $\sim />67.7 \mathrm{Ma}$ (BKSA95).

(4) Larson and Opdyke (1979, p. 787) noted that Bukry (1974) recorded M. mura at the base of DSDP Hole 39 (Madagascar Basin, Indian Ocean) which was drilled on reversely magnetized oceanic basement just older than Anomaly 31 (Schlich, 1974). This anomalous record may be due to taxonomic problems associated with the identification of $M$. mura (fide Bralower, written communication, 1997).

(5) In the Gubbio section (Apennines, Northern Italy) Monechi and Thierstein (1985) recorded the FAD of L. quadratus (nominate taxon of Zone $\mathrm{NC} 22 ; 326 \mathrm{~m})$ near the base of Chron C31n (324 m), the FAD of A. mayaroensis (330 m), and the FAD of $M$. mura $(337.9 \mathrm{~m})$ in the younger part of Chron C30n (top at $345 \mathrm{~m}$ ). Using the K/P boundary (mid-Chron $\mathrm{C} 29 \mathrm{r} ; 347.6 \mathrm{~m}$ ) and the boundaries of Chrons $\mathrm{C} 29 \mathrm{n} / \mathrm{C} 30 \mathrm{n}$ and $\mathrm{C} 31 \mathrm{n} / \mathrm{r}$ ( $345 \mathrm{~m}$ and $324 \mathrm{~m}$, respectively) as interpolation calibration points yields estimates of $68.42 \mathrm{Ma}$, 67.74 Ma and 66.54 Ma for the FADs of L. quadratus, A. mayaroensis and $M$. mura, respectively. This suggests that the FAD of $A$. mayaroensis is within the mid-later part of Chron C31n (the two normal chrons are concatenated in Gubbio and it 
is not possible to determine from its relative stratigraphic position in the section just where in the chron sequence it occurs).

(6) A compilation of shipboard data for DSDP Hole 516F (Berggren et al., 1983, fig. 2, pp. 942 944) indicates that:

(a) the FAD of $A$. mayaroensis is within Chronozone C31r (pre-dating the FAD of $L$. quadratus);

(b) the L. quadratus zone is correlative with Chronozone C $31 \mathrm{n}$; the $N$. frequens zone is correlative with most of Chronozones C31n-C30n; and the $M$. mura zone is correlative with the upper part of Chronozone C30n and pre-K/P boundary part of Chronozone C29r.

(7) A compilation by Ehrendorfer (1993) has shown that:

(a) the FAD of $A$. mayaroensis spans the temporal interval (BKF85) of early Chron C31r (ODP Hole 690C, $\sim 71 \mathrm{Ma}$ ) to late Chron C31n (DSDP Site 524, $68.7 \mathrm{Ma}$ );

(b) the FAD of L. quadratus spans the temporal interval of early Chron C31n (Bottacione section, $\sim 69.3 \mathrm{Ma}$ ) to mid-Chron C31n (DSDP Site 527, $\sim 67.8 \mathrm{Ma}$ );

(c) the FAD of $N$. frequens spans the temporal interval from early Chron C31n (DSDP 524, $\sim 69.1 \mathrm{Ma}$ ) to mid-Chron C30n (DSDP Site 527, $\sim 67.5 \mathrm{Ma}$ ) with a single 'outlier' in early Chron C31r (ODP Hole 690C, 70.8 Ma);

(d) the FAD of $M$. mura, while consistently associated with Chron C30n, spans the temporal interval of early Chron C30n (DSDP Hole 577A, $\sim 68.35 \mathrm{Ma}$ ) to early late Chron C30n (DSDP Site 527, 67.15 Ma);

(e) the overlap of $N$. frequens and $M$. mura occurs consistently within Chron C30n.

(8) The FADs of A. mayaroensis and L. quadratus have been shown to occur at the base of, and in the lower part of, Chronozone $\mathrm{C} 31 \mathrm{n}$, respectively and the FAD of $M$. mura in the upper part of Chronozone C30n, based on a compilation of various data sources [cf. Bralower et al., 1995, fig. 71, in which the FAD of L. quadratus (and the base of Zone CC22) is correlated with the base of Chronozone $\mathrm{C} 30 \mathrm{n}$, rather than $\mathrm{C} 31 \mathrm{n}$, and the relative temporal duration of Chrons $\mathrm{C} 31 \mathrm{n}$ and $\mathrm{C} 30 \mathrm{n}$ are out of correct proportions: Chron C30n has approximately twice the duration of Chron C31n (2.032 my vs. 1.002 my, BKSA95, p. 133)].

(9) The above data support/validate identification of Chrons C30 and C31 between 169 and $171.7 \mathrm{~m}$ in Hole 384.

\section{Appendix 2}

Since the publication of BKSA95 we have recognized, and been informed of, several misprints and/or errors in the text/tables of that paper by alert colleagues. We take this opportunity of clarifying/correcting these inadvertent errors.

(1) The P1b/c boundary (FAD of Gl. compressa) is drawn at $62.5 \mathrm{Ma},=$ Chron $\mathrm{C} 28 \mathrm{n} / \mathrm{r}$ boundary in BKSA95, fig. 1, whereas the correct value (63.0 Ma; mid-Chron $\mathrm{C} 28 \mathrm{n})$ is given on p. 147 (BKSA95) in the discussion of Subzone P1c and in table 8, p. 149, item 28. This value has been corrected slightly in this paper to $62.87 \mathrm{Ma}$.

(2) BKSA95, table 8, p. 148, item 6: Acarinina acarinata should read Acarinina nitida.

(3) BKSA95, table 8, p. 148, item 17: Parasubbotina variolaria should read Parasubbotina variospira.

(4) BKSA95, table 8, p. 148, item 19: Muricella albeari should read Igorina albeari at the time the manuscript went to press members of the Paleogene Planktonic Foraminiferal Working Group were debating the correct taxonomic/ generic name for members of the 'biconvex morozovellid' (igorinid) lineage. Muricella had been proposed as a provisional name, although it was subsequently recognized that the generic name Igorina was both available and appropriate for this group; see Berggren and Norris, 1997; Olsson et al., 1999].

(5) BKSA95, table 8, p. 148, item 22: Muricella pusilla should read Igorina pusilla. See remark above under (4).

(6) BKSA 95, table 9, p. 155, item 7: LAD Porticulasphaera semiinvoluta should read Chron C16n.2n with age estimate of $35.7 \mathrm{Ma}$ [rather than Chron $\mathrm{C} 15 \mathrm{r}_{(\mathrm{o})}$ at $35.3 \mathrm{Ma}$ as shown]. Chron identification in Remarks is correct; incorrect chron identification/values inadvertently entered. 
(7) BKSA95, table 11, p. 174, item 5: FAD Globorotalia zealandica should read LAD.

(8) BKSA95, table 11, p. 174, items 15-18 have been incorrectly entered/assigned to magnetchrons. Correct assignments are as follows.

(a) Item 17: FAD Globoquadrina dehiscens spinosa Chron $\mathrm{CBr} 23.2 \mathrm{Ma}$.

(b) Item 18: LAD Globoquadrina globularis Chron C6AAr 22.6 Ma.

(c) Item 16: LAD Globorotalia pseudokugleri Chron C6Br 23.2 Ma.

(d) Item 15: LAD Globoturborotalia angulisuturalis Chron $\mathrm{C} 6 \mathrm{Br}$ 23.2 Ma.

(9) BKSA95, table 11, p. 174, item 19: FAD Globoquadrina dehiscens is correct. $\mathrm{X}$ also entered under LAD is incorrect.

(10) BKSA95, table 12, p. 175, item 6: Globorotalia fohsi robusta LAD in Chron C5An.1r should read C5An.1n (same as item 5, G. fohsi lobata above). Discussion entry under this item (6) should be under item (7), the FAD of G. fohsi robusta $=$ Mn9/10 subzonal boundary.

(11) BKSA95, table 13, p. 176, item 6: FAD Globorotalia margaritae at $6.0 \mathrm{Ma}$ should read 6.4 Ma (see Berggren et al., 1995, table 5, p. 1280).

(12) BKSA95, table 17, p. 192, item 23: LAD Triquetrorhabdulus carinatus should read FAD $T$. carinatus.

(13) BKSA95, table 17, p. 193, item 26: LAD Triquetrorhabdulus serratus should read FAD $T$. serratus.

(14) BKSA95, table 17, p. 193, item 28: LAD Sphenolithis umbrellus in Chron C6n.1r should read C6n. 1n at 23.5 Ma.

\section{References}

Alvarez, W., Arthur, M.A., Fisher, A.G., Lowrie, W., Napoleone, G., Premoli Silva, I., Roggenthen, W.M., 1977. Upper Cretaceous-Paleocene magnetic stratigraphy at Gubbio, Italy. V. Type section for the Late Cretaceous-Paleocene geomagnetic reversal time scale. Geol. Soc. Am. Bull. 88, 367-389.

Arenillas, I., Molina, E., 1996. Bioestratigrafia y evolucion de las asociaciones de foraminiferos planctonicos del transito Paleoceno-Eoceno en Alamedilla (Cordilleras Beticas). Rivista Espanola Micropaleontologia 18 (1), 75-96.

Aubry, M.-P., 1993. Neogene allostratigraphy and depositional history of the De Soto Canyon area, northern Gulf of Mexico. Micropaleontology 39, 327-366.

Aubry, M.-P., 1995. From chronology to stratigraphy: interpreting the lower and middle Eocene stratigraphic record in the Atlantic Ocean. In: Berggren, W.A., Kent, D.V., Aubry, M.-P., Hardenbol, J. (Eds.), Geochronology, Time Scales and Global Stratigraphic Correlation, SEPM Spec. Publ. 54, 213-274.

Aubry, M.-P., 1996. Towards an upper Paleocene-lower Eocene high resolution stratigraphy. In: Aubry, M.-P., Benjamini, C. (Eds.), Paleocene/Eocene Boundary Events in Space and Time, Israel J. Earth Sci. 44, 239-253.

Aubry, M.-P., 1998. Stratigraphic (dis)continuity and temporal resolution of geological events in the upper Paleocene-lower Eocene deep sea record. In: Aubry, M.-P., Lucas, S., Berggren, W.A. (Eds.), Late Paleocene-Early Eocene Climatic and Biotic Events. Columbia University Press, New York, in press.

Aubry, M.-P., Villa, G., 1996. Calcareous nannofossil stratigraphy of the Lemme Carrosio Paleogene/Neogene Global Boundary Section and Point. Giornale di Geologia, ser. 3 $581 / 2,51-69$.

Aubry, M.-P., Hailwood, E.A., Townsend, H.A., 1986. Magnetic and calcareous-nannofossil stratigraphy of lower Palaeogene formations of the Hampshire and London basins. J. Geol. Soc. London 143, 729-735.

Aubry, M.-P., Berggren, W.A., Stott, L., Sinha, A., 1996. The upper Paleocene-lower Eocene stratigraphic record and the Paleocene-Eocene boundary carbon isotope excursion: implications for geochronology. In: Knox, R.W.O'B., Corfield, R.M., Dunay, R.E. (Eds.), Correlation of the Early Paleogene in Northwest Europe, Geol. Soc. Spec. Publ. 101, 353-380.

Barrera, E., 1994. Global environmental changes preceding the Cretaceous-Tertiary boundary: early-late Maastrichtian transition. Geology 22, 877-880.

Barrera, E., Keller, G., 1994. Productivity across the Cretaceous/Tertiary boundary in high latitudes. Geol. Soc. Am. Bull. 106, 1254-1266.

Berggren, W.A., 1969. Rates of evolution of some Cenozoic planktonic foraminifera. Micropaleontology 15, 351-365.

Berggren, W.A., Aubry, M.-P., 1998a. The Paleocene/Eocene Epoch/Series boundary: chronostratigraphic framework and estimated chronology. In: Aubry, M.-P., Lucas, S., Berggren, W.A. (Eds.), Late Paleocene-Early Eocene Climatic and Biotic Events in the Marine and Terrestrial Records. Columbia University Press, New York, pp. 18-36.

Berggren, W.A., Aubry, M.-P., 1998b. The Paleocene/Eocene Epoch/System boundary: chronostratigraphic framework and estimated geochronology. In: Aubry, M.-P., Lucas, S.G., Berggren, W.A. (Eds.), Late Paleocene-Early Eocene Climatic and Biotic Events in the Marine and Terrestrial Records. Columbia University Press, New York, pp. 18-36.

Berggren, W.A., Miller, K.G., 1988. Paleogene tropical planktonic foraminiferal biostratigraphy and magnetobiochronology. Micropaleontology 34 (4), 362-380.

Berggren, W.A., Norris, R.D., 1993. Origin of the genus Aca- 
rinina and revision to Paleocene biostratigraphy. Geol. Soc. Am. Ann. Meet., Abstr. Progr. 25, A359.

Berggren, W.A., Norris, R.D., 1997. Biostratigraphy, phylogeny and systematics of Paleocene trochospiral planktic Foraminifera. Micropaleontology 43 Suppl. 1116 pp.

Berggren, W.A., Hamilton, N., Johnson, D.A., Pujol, C., Weiss, W., Cepek, P., Gombos Jr., A.M., 1983. Magnetobiostratigraphy of Deep Sea Drilling Project, Leg 72, Sites 515-518, Rio Grande Rise (South Atlantic). In: Barker, P.F., Carlson, R.L., Johnson, D.A., et al., (Eds.), Initial Reports of the Deep Sea Drilling Project Vol. 72. US Government Printing Office, Washington, DC, pp. 939-948.

Berggren, W.A., Kent, D.V., Flynn, J.J., 1985. Paleogene geochronology and chronostratigraphy. In: Snelling, N.J. (Ed.), The Chronology of the Geological Record. London, Geological Society of London Memoir 10, 141-195.

Berggren, W.A., Norris, R.D., Aubry, M.-P., Van Fossen, M.C., 1994. A Paleocene magnetic, biochronologic and isotopic reference section at DSDP Site 384. Am. Geophys. Union Spring Meet., EOS Trans. AGU-75 (16), 52

Berggren, W.A., Kent, D.V., Swisher, C., Aubry, M.-P., 1995. A revised Cenozoic geochronology and chronostratigraphy. In: Berggren, W.A., Kent, D.V., Aubrey, M.-P., Hardenbol, J. (Eds.), Geochronology, Time-Scales and Global Stratigraphic Correlation. Tulsa, SEPM Special Publication 54, 129-212.

Blow, W.H., 1979. The Cenozoic Globigerinidae: A Study of the Morphology, Taxonomy, Evolutionary Relationships and the Stratigraphical Distribution of some Globigerinidae (Mainly Globigerinaceae). E.J. Brill, Leiden. 3 vols., $1413 \mathrm{pp}$.

Boersma, A., Shackleton, N.J., Hall, M., Given, Q., 1979. Carbon and oxygen isotope records at DSDP Site 384 (North Atlantic) and some Paleocene paleotemperatures and carbon isotope variations in the Atlantic Ocean. In: Tucholke, B.E., Vogt, P.R., et al., (Eds.), Initial Reports of the Deep Sea Drilling Project Vol. 43. US Government Printing Office, Washington, DC, pp. 695-717.

Bolli, H.M., 1966. Zonation of Cretaceous to Pliocene marine sediments based on planktonic foraminifera. Boletin Informativo, Asociacion Venezolano de Geologia, Mineraria y Petroleo v. 9, 3-32.

Bralower, T.J., Mutterlose, J., 1995. Calcareous nannofossil biostratigraphy of site 865, Allison Guyot, Central Pacific Ocean: a tropical Paleogene reference section. In: Winterer, E.L., Sager, W.W., Firth, J.V., Sinton, J.M. (Eds.), Proc. Ocean Drilling Program, Scientific Results Vol. 143. Ocean Drilling Program, College Station, TX, pp. 31-74.

Bralower, T.J., Parrow, M., 1996. Morphometrics of the Paleocene coccolith genera Cruciplacolithus, Chiasmolithus, and Sullivania: a complex evolutionary history. Paleobiology 22 (3), 352-385.

Bralower, T., Leckie, R.M., Sliter, W.V., Thierstein, H.R., 1995. An integrated Cretaceous microfossil biostratigraphy, Geochronology, Time Scales and Global Stratigraphic Correlation, Berggren, W., Kent, D.V., Aubry, M.-P., Hardenbol, J. (Eds.), SEPM Spec. Publ. 54, 65-79.
Bukry, D., 1974. Phytoplankton stratigraphy, offshore East Africa, Deep Sea Drilling Project, Leg 25. In: Simpson, E.S.W., Schlich, R., et al., (Eds.), Initial Reports of the Deep Sea Drilling Project Vol. 25. US Government Printing Office, Washington, DC, pp. 635-646.

Cande, S.C., Kent, D.V., 1992. A new geomagnetic polarity time scale for the Late Cretaceous and Cenozoic. J. Geophys. Res. 97, 13,917-13,951.

Cande, S., Kent, D.V., 1995. Revised calibration of the geomagnetic polarity time scale for the Late Cretaceous and Cenozoic. J. Geophys. Res. 100, 6093-6095.

Chave, A.D., 1984. Lower Paleocene-Upper Cretaceous magnetostratigraphy, Sites 525, 527, 528 and 529, Deep Sea Drilling Project, Leg 74. In: Moore, T.C., Rabinowitz, P.D., et al., (Eds.), Initial Reports of the Deep Sea Drilling Project Vol. 74. US Government Printing Office, Washington, DC, pp. 525-531.

Corfield, R.M., Norris, R.D., 1996. Deep water circulation in the Paleocene Ocean. In: Knox, R.W.O'B., Corfield, R.M., Dunay, R.E. (Eds.), Correlation of the Early Paleogene in Northwest Europe, Geol. Soc. Spec. Publ. 101, 443-456.

Corfield, R.M., Cartlidge, J.E., Premoli Silva, I., Hosley, R.A., 1991. Oxygen and carbon isotope stratigraphy of the Paleogene and Cretaceous limestones in the Bottaccione Gorge and the Contessa Highway sections, Umbria, Italy. Terra Nova 3, 414-422.

Ehrendorfer, T.W., 1993. Late Cretaceous (Maastrichtian) calcareous nannoplankton biogeography: with emphasis on events immediately preceding the Cretaceous/Paleocene boundary. Unpublished Ph.D. Thesis, MIT-WHOI, 288 pp.

Foreman, H.P., 1973. Radiolaria of Leg 10 with systematics and ranges for the families Amphipyndacidae, Artostrobiidae and Theoperidae. In: Worzel, J.L., Bryant, W., et al., (Eds.), Initial Reports of the Deep Sea Drilling Project Vol. 10. US Government Printing Office, Washington, DC, pp. 407-474.

Gradstein, F., Agterberg, F.P., Ogg, J.G., Hardenbol, J., van Veen, P., Thierry, J., Huang, Z., 1995. A Triassic, Jurassic and Cretaceous time scale. In: Berggren, W., Kent, D.V., Aubry, M.-P., Hardenbol, J. (Eds.), Geochronology, Time Scales and Global Stratigraphic Correlation, SEPM Spec. Publ. 54, 95-126.

Hamilton, N., 1990. Mesozoic magnetostratigraphy of Maud Rise, Antarctica. In: Barker, P., Kennett, J.P., et al., (Eds.), Proceedings of the Ocean Drilling Program, Scientific Results, Vol. 113, 255-260.

Kelly, D.C., Bralower, T.J., Zachos, J.C., Premoli-Silva, I., Thomas, E., 1996. Rapid diversification of planktonic foraminifera in the tropical Pacific (ODP Site 865) during the late Paleocene Thermal Maximum. Geology 24, 423-426.

Kennett, J.P., Stott, L.D., 1991. Abrupt deep-sea warming, palaeoceanographic changes and benthic extinctions at the end of the Palaeocene. Nature 353, 225-229.

Kirschvink, J.L., 1980. The least-squares line and plane and the analysis of paleomagnetic data. Roy. Astron. Soc. Geophys. J. 62, 699-718.

Koch, P.L., Zachos, J.C., Gingerich, P.D., 1992. Correlation 
between isotope records in marine and continental carbon reservoirs near the Palaeocene/Eocene boundary. Nature 358, 319-322.

Larson, P.A., Opdyke, N.D., 1979. Paleomagnetic results from Early Tertiary/Late Cretaceous sediments of Site 384. In: Tucholke, B.E., Vogt, P.R., et al., (Eds.), Initial Reports of the Deep Sea Drilling Project Vol.43. US Government Printing Office, Washington, DC, pp. 785-788.

Lowrie, W., Alvarez, W., 1977. Upper Cretaceous-Paleocene magnetic stratigraphy at Gubbio, Italy. III. Upper Cretaceous magnetic stratigraphy. Bulletin Geological Society of America 88, 374-377.

Manivit, H., Feinberg, H., 1984. Correlation of magnetostratigraphy and nannofossil biostratigraphy in Upper Cretaceous and lower Paleocene sediments of the Walvis Ridge area. In: Moore, P.D., Rabinowitz, T.C., et al., (Eds.), Initial Reports of the Deep Sea Drilling Project Vol. 74. US Government Printing Office, Washington, DC, pp. 469-474.

Martini, E., 1971. Standard Tertiary and Quaternary calcareous nannoplankton zonation. In: Farinacci, A. (Ed.), Proc. 2nd Planktonic Conf., Rome, 1970. Tecnoscienza, pp. 739-785.

McNulty, C.L., 1979. Smaller Cretaceous foraminifers of Leg 43, Deep Sea Drilling Project. In: Tucholke, B.E., Vogt, R., et al., (Eds.), Initial Reports of the Deep Sea Drilling Project Vol. 43. US Government Printing Office, Washington, DC, pp. 487-505.

Miller, K.G., Fairbanks, R.G., Mountain, G., 1987. Tertiary oxygen isotope synthesis, sea-level history, and continental margin erosion. Paleoceanography 1, 1-19.

Molina, E., Arenillas, I., Pardo, A., 1999. High resolution planktic foraminiferal biostratigraphy and correlation across the Paleocene/Eocene boundary in the Tethys. Bull. Soc. géol. Fr., in press.

Monechi, S., Thierstein, H., 1985. Late Cretaceous-Eocene nannofossil and magnetostratigraphic correlations near Gubbio, Italy. Marine Micropaleontol. 9, 419-440.

Monechi, S., Bleil, U., Backman, J., 1985. Magnetobiochronology of late Cretaceous-Paleogene and late Cenozoic pelagic sedimentary sequences from the northwest Pacific (Deep Sea Drilling Project, Leg 86, Site 577). In: Heath, G.R., Burckle, L.H., et al., (Eds.), Initial Reports of the Deep Sea Drilling Project Vol. 86. US Government Printing Office, Washington, DC, pp. 787-797.

Napoleone, G., Premoli Silva, I., Heller, F., Cheli, P., Corezzi, S., Fischer, A.G., 1983. Eocene magnetic stratigraphy at Gubbio, Italy, and its implications for Paleogene geochronology. Geol. Soc. Am. Bull. 94, 181-191.

Nishimura, A., 1987. Cenozoic Radiolarain the western North Atlantic, Site 603, Leg 93 of the Deep Sea Drilling Project. In: van Hinte, J.E., Wise Jr., S.W., et al., (Eds.), Initial Reports of the Deep Sea Drilling Project Vol. 93. US Government Printing Office, Washington, DC, pp. 713-737.

Nishimura, A., 1992. Paleocene radiolarian biostratigraphy in the northwest Atlantic at Site 384, Leg 43, of the Deep Sea Drilling Project. Micropaleontology 38, 317-362.

Norris, R.D., Röhl, U., 1999. Carbon cycling and chronology of climate warming during the Palaeocene/Eocene transition. Nature 401, 775-777.

Okada, H., Bukry, D., 1980. Supplementary modification and introduction of code numbers to the low-latitude coccolith biostratigraphic zonation. Marine Micropaleontol. 5, 321-325.

Okada, H., Thierstein, H.R., 1979. Calcareous nannoplankton, Leg 43, Deep Sea Drilling Project. In: Tucholke, B.E., Vogt, R., et al., (Eds.), Initial Reports of the Deep Sea Drilling Project Vol. 43. US Government Printing Office, Washington, DC, pp. 507-573.

Olsson, R.K., Hemleben, C., Berggren, W.A., Huber, B.T. (Eds.), Atlas of Paleocene Planktonic Foraminifera. Smithsonian Contributions to Paleobiology No. 85. 1999, 252 pp., 71 plates.

Pak, D.K., Miller, K.G., 1992. Paleocene to Eocene benthic foraminiferal isotopes and assemblages: implications for deepwater circulation. Paleoceanography 7, 405-422.

Pardo, A., Keller, G., Oberhansli, H., 1999. Paleoecologic and paleoceanographic evolution of the Tethyan realm during the Paleocene-Eocene transition. J. Foramniferal Res. 29 (1), 37-57.

Quillévéré, F., 1996. Magnétobiochronogie des Foraminifères planctoniques paléocènes, DSDP Site 384 (Nord-Ouest Atlantique): Etude quantitative et implications paléoécologique. Académie de Montpellier, Université Montpellier II, Sciences et techniques du Languedoc, DEA Thesis (DEA) Paléontologie (unpublished), 33 pp, 6 plates, appendices.

Rabinowitz, P.D., Cande, S.C., Hayes, D.E., 1979. The JAnomaly in the central North Atlantic. In: Tucholke, B.E., Vogt, R., et al., (Eds.), Initial Reports of the Deep Sea Drilling Project Vol. 43. US Government Printing Office, Washington, DC, pp. 879-885.

Robaszynski, F., Caron, M., et al., 1984. Atlas of Late Cretaceous planktonic foraminifera. Rev. Micropaleontol. 26 3/ 4, 145-305.

Roggenthen, W.M., Napoleone, G., 1977. Upper CretaceousPaleocene magnetic stratigraphy at Gubbio, Italy. IV. Upper Maastrichtian-Paleocene magnetic stratigraphy. Geol. Soc. Am. Bull. 88, 378-382.

Sanfilippo, A., Nigrini, C., 1998. Upper Paleocene-Lower Eocene deep-sea radiolarian stratigraphy and the Paleocene/ Eocene Series boundary. In: Aubry, M.-P., Lucas, S., Berggren, W.A. (Eds.), Late Paleocene-Early Eocene Climatic and Biotic Events in the Marine and Terrestrial Records. Columbia University Press, New York, pp. 245-276.

Sanfilippo, A., Westberg-Smith, M.J., Riedel, W.R., 1985. Cenozoic Radiolaria. In: Bolli, H.M., Saunders, J.B., PerchNielsen, K. (Eds.), Plankton Stratigraphy. Cambridge University Press, Cambridge, pp. 631-712.

Schlich, R., 1974. Sea floor spreading history and deep-sea drilling results of the Madagascar and Mascarene basins, western Indian Ocean. In: Simpson, E.S.W., Schlich, R., et al., (Eds.), Initial Reports of the Deep Sea Drilling Project Vol. 25. US Government Printing Office, Washington, DC, pp. 663-678.

Shackleton, N.J., Hall, M.A., 1985. Carbon isotope data from 
Leg 74 sediments. In: Moore, T.C., Rabinowitz, P.D., et al., (Eds.), Initial Reports of the Deep Sea Drilling Project, Leg 74. US Government Printing Office, Washington, DC, pp. 613-619.

Shackleton, N.J., Members of the Shipboard Scientific Party, 1979. Accumulation rates in Leg 74 sediments. In: Moore, T.C., Rabinowitz, P.D., et al., (Eds.), Initial Reports of the Deep Sea Drilling Project Vol. 74. US Government Printing Office, Washington, DC, pp. 621-644.

Shackleton, N., Members of the Shipboard Scientific Party, 1984. Accumulation rates in Leg 74 sediments. In: Moore Jr., T.C., Rabinowitz, P.D., et al., (Eds.), Initial Reports of the Deep Sea Drilling Project v. 74. US Government Printing Office, Washington, pp. 621-644.

Shutskaya, E.K., 1965. Nizhnii Paleogen Kryma, Predkavkaz'ya zapadonoi chasti Sredni Azii. Geologicheskaya Institut Nauk, Akademiya Nauk SSSR, Gosgeolkoma SSSR, Moscow.

Shutskaya, E.K., 1970. Stratigrafiya, foraminifery i paleogeografiya nizhnego Paleogena Kryma, P:redkavkaz'ya i zapadnoi chasti Srednei Azii. Vessoyuznyi NauchnoIssledovatel'skii Geologo-Razvedochnyi Neftyanoi Institut (VNIGNI), Trudy 70. 256 pp.

Sinha, A., Aubry, M.-P., Stott, L.D., Thiry, M., Berggren, W.A., 1996. Chemostratigraphy of the 'lower' Sparnacian deposits (Argiles plastiques bariolées) of the Paris BasinPaleocene/Eocene Boundary Events in Space and Time, Aubry, M.-P., Benjamini, C. (Eds.), Israel J. Earth Sci. 44, 223-237.

Speijer, R.P., Schmitz, B., Luger, P., 1999. Stratigraphy of late Paleocene events in the Middle East: implications for low to middle latitude successions and correlations. Geol. Soc. London, in press.
Stott, L.D., Kennett, J.P., 1990. Antarctic Paleogene planktonic foraminiferal biostratigraphy: ODP Leg 113, Sites 689 and 690. In: Proc. Ocean Drilling Program, Scientific Results, College Station Vol. 13, 549-569.

Thierstein, H.R., 1980. Selective dissolution of Late Cretaceous and earliest Tertiary calcareous nannofossils: experimental evidence. Cretaceous Res. 2, 165-176.

Thierstein, H.R., 1981. Late Cretaceous nannoplankton and the change at the Cretaceous-Tertiary boundary. SEPM Spec. Publ. 32, 355-394.

Thierstein, H.R., Okada, H., 1979. The Cretaceous/Tertiary boundary event in the North Atlantic. In: Tucholke, B.E., Vogt, R., et al., (Eds.), Initial Reports of the Deep Sea Drilling Project Vol. 43. US Government Printing Office, Washington, DC, pp. 601-616.

Tucholke, B.E., Vogt, P.R., 1979. Western North Atlantic: sedimentary evolution and aspects of tectonic history. In: Tucholke, B.E., Vogt, R., et al., (Eds.), Initial Reports of the Deep Sea Drilling Project Vol.43. US Government Printing Office, Washington, DC, pp. 791-825.

Tucholke, B.E., Vogt, P.R., et al., (Eds.), Initial Reports of the Deep Sea Drilling Project Vol. 43. 1979. US Government Printing Office, Washington, DC.

Van der Voo, R., 1990. Phanerozoic paleomagnetic poles from Europe and North America and comparisons with continental reconstructions. Rev. Geophys. 28, 167-206.

Wei, W., Wise, W., 1989. Paleogene calcareous nannofossil magnetobiochronology: results from South Atlantic DSDP Site 516. Marine Micropaleontol. 14, 119-152.

Zachos, J.C., Stott, L.D., Lohmann, K.C., 1994. Evolution of early Cenozoic marine temperatures. Paleoceanography 9, 353-387. 